\title{
The Zoogonidae (Digenea) of fishes from the north-east Atlantic
}

\author{
Rodney A. Bray \& David I. Gibson
}

Department of Zoology, British Museum (Natural History), Cromwell Road, London SW7 5BD

\section{Contents}

Synopsis .

Introduction

Materials and methods

Systematic section

Family Zoogonidae

Key to the subfamilies

Subfamily Zoogoninae

Zoogonus rubellus .

Diphterostomum brusinae

Diphterostomum betencourti .

Diphterostomum vividum

Pseudozoogonoides subaequiporu.

Pseudozoogonoides sp. innom.

Zoogonoides viviparus
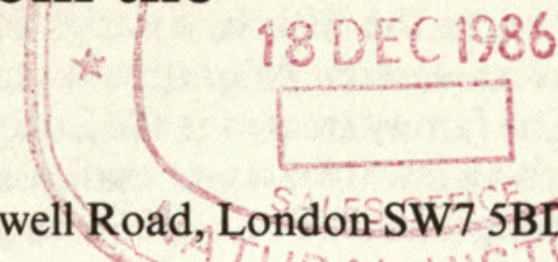

Subfamily Lepidophyllinae

Lepidophyllum steenstrupi

Lepidophyllum appyi

Panopula bridgeri .

Panopula spinosa.

Brachyenteron pycnorganum .

Brachyenteron campbelli

Steganodermatoides maceri .

Neosteganoderma glandulosum

Proctophantastes abyssarum .

Steganoderma (Lecithostaphylus) retroflexum

\section{Synopsis}

Keys, original descriptions, lists of synonyms, full host-records, locality data and comments on some aspects of their biology are presented for all of the zoogonid species recorded from the north-eastern Atlantic region. The species described are Zoogonus rubellus, Diphterostomum brusinae, D. betencourti, D. vividum n. comb., Pseudozoogonoides subaequiporus n. comb., Pseudozoogonoides sp. innom., Zoogonoides viviparus, Lepidophyllum steenstrupi, L. appyi sp. nov., Panopula bridgeri sp. nov., P. spinosa n. comb., Brachyenteron pycnorganum, B. campbelli sp. nov., Steganodermatoides maceri sp. nov., Neosteganoderma glandulosum, Proctophantastes abyssorum and Steganoderma (Lecithostaphylus) retroflexum.

In addition, Zoogonus lasius from the north-west Atlantic is considered distinct from Z. rubellus. The new combination Proctophantastes gillissi is formed. 


\section{Introduction}

This is the fifth in a series of papers in which the digenean fauna of the marine fishes of the north-eastern Atlantic is discussed (see Bray \& Gibson, 1977, 1980; Gibson \& Bray, 1977, 1986). The family treated is the Zoogonidae, a widespread group, restricted to fishes, mainly marine but with a few freshwater examples. One of us has completed a general taxonomic review of the family Zoogonidae (Bray, 1985b, in press $a, b$ ).

\section{Materials and methods}

The materials used in this investigation and the areas of study are as outlined by Bray \& Gibson (1977). The collecting trips undertaken are as reported in previous contributions in this series, but also include the northern North Sea and off northern Scotland aboard DAFS RV Scotia in 1985 (by R.A.B). The taxonomic methods used are outlined in the general review articles (Bray, 1985b, in press $a, b)$.

\section{Systematic section}

\section{Family ZOOGONIDAE Odhner, 1902}

Steganodermatidae Yamaguti, 1934.

DiAGNOSTIC FEATURES. Body small to large, elongate cylindrical to flattened spatulate. Body surface usually spinose. Ventral sucker small to large; simple, ornamented or transversely divided. Prepharynx long to absent. Oesophagus long to absent, bifurcates in forebody to anterior hindbody. Caeca two, short saccular to long; terminating in forebody to reaching to posterior extremity. Cirrus-sac well developed. Genital pore marginal or submarginal, usually sinistral. Ovary usually pre-testicular. Seminal vesicle and Laurer's canal present. Uterus usually reaches to posterior extremity. Eggs with tanned shells or membranous capsules. Vitellarium single or double mass or follicular. Excretory pore terminal, vesicle short saccular to long tubular Ishaped. In alimentary canal, gall-bladder, bile-duct of urinary bladder or teleosts or occasionally elasmobranchs.

\section{Key to the subfamilies}

1 Vitellarium median, small globular or bilobed mass. Egg capsules membranous or very weakly tanned . . . . ZOOGONINAE Odhner, 1902 (p.

- Vitellarium follicular in two lateral symmetrical fields. Egg capsules strongly tanned, forming shells

LEPIDOPHYLLINAE Stossich, 1903 (p. 160)

Subfamily ZOOGONINAE Odhner, 1902

Key to the genera of the Zoogoninae from the north-east Atlantic

1 Vitelline mass single.

- Vitelline mass bilobed (double).

2 Genital pore and intestinal bifurcation in mid-forebody. Caeca narrow Zoogonoides Odhner, 1902 (p. 151)

- Genital pore at level of ventral sucker. Intestinal bifurcation dorsal to ventral sucker or in hindbody. Caeca short, saccular . Z Zoogonus Looss, 1901, (p.

3 Caeca short, saccular, divergent. No atrial sac. Muscular lamellar lips may occur on ventral sucker. Ovary pre- or inter-testicular. Diphterostomum Stossich, 1903 (p. 135)

- Caeca long, parallel. Atrial sac present. No muscular lips on ventral sucker 
Genus ZOOGONUS Looss, 1901

Diagnostic Features. Prepharynx distinct, short to long. Oesophagus bifurcates dorsally to ventral sucker or in anterior hindbody. Caeca short saccular. Cirrus-sac elongate with bipartite seminal vesicle. Genital pore marginal at about level of ventral sucker. Ovary globular to oval, between caeca. Vitellarium single, globular. Egg-capsule membranous. Excretory vesicle short sac. Sporocysts in gastropods. Tail-less xiphidiocercaria. Metacercariae in echinoderms, polychaetes and gastropods. Adults in marine teleosts.

COMmEnt. Only one species occurs in the north-east Atlantic.

\section{Zoogonus rubellus (Olsson, 1868) Odhner, 1902}

Distoma rubellum Olsson, 1868.

Lecithodendrium rubellum (Olsson, 1868) Stossich, 1899.

Zoogonus mirus Looss, 1901.

(?) Cercariaeum reticulatum Stunkard, 1932.

(?) Zoogonus sp. of Richard (1971).

TYPE-HOST AND LOCALITY. Labrus bergylta, Bergen, Norway.

\section{RECORDS}

(i) Material studied

(a) From the NE Atlantic

Anarhichas lupus [posterior intestine] Kristineberg, Sweden (Jan. 1971). Material studied for us by J. Thulin. [rectum] Off NE Scotland $\left(58^{\circ} \mathrm{N}, 00^{\circ}\right.$; depth $99-111 \mathrm{~m} ; \& 59^{\circ} \mathrm{N}, 01^{\circ} \mathrm{E}$; depth $107-117 \mathrm{~m} ;$ Dec. 1979) BM(NH) 1982.1.20.1-5; Bell Rock, North Sea $\left(56^{\circ} \mathrm{N}, 02^{\circ} \mathrm{E}\right.$; depth $52 \mathrm{~m}$; May 1982) and Copinsay, North Sea $\left(59^{\circ} \mathrm{N}, 02^{\circ} \mathrm{W}\right.$; depth $75 \mathrm{~m}$; June 1983$) \mathrm{BM}(\mathrm{NH})$ 1983.11.23.19-22.

Labrus bergylta [intestine] Kristineberg, Sweden (Aug. 1976). BM(NH) 1982.1.20.6-7.

Labrus bimaculatus [intestine] Plymouth, Devon, England (May 1932). BM(NH) 1932.11.25.53-64 (see Baylis \& Jones, 1933: 630).

Limanda limanda [intestine] Plymouth, Devon, England (May, 1932). BM(NH) 1932.11.25.65-66 (see Baylis \& Jones, 1933: 630

Platichthys flesus [rectum] Plymouth, Devon, England (May 1972). BM(NH) 1982.1.20.8

Pleuronectes platessa [intestine, rectum] Plymouth, Devon, England (May 1972). BM(NH) 1982.1.20.9-10.

(b) From elsewhere

None

(ii) NE Atlantic records from the literature

Anarhichas lupus [rectum, lower intestine] St Andrews Bay, Scotland. Nicoll (1909a: 17).

Blennius pholis [rectum] Roscoff, Finistère, France. Sproston (1939: 40).

Labrus bergylta [intestine] Bergen, Norway. Olsson (1868: 40).

[?] Kristineberg, Sweden. Odhner (1902: 59).

Labrus bimaculatus [intestine] Plymouth, Devon, England. Baylis \& Jones (1933: 630); Baylis (1939: 483).

Limanda limanda [intestine] Plymouth, Devon, England. Baylis \& Jones (1933: 630); Baylis (1939: 483).

Pleuronectes platessa [?] Roscoff, Finistère, France. Sproston (1939: 40).

Trachurus trachurus [intestine] near Straits of Gibraltar. Kovaleva (1969: 132; 1970: 52); Gaevskaya \& Kovaleva (1980a: 53; 1980b: 19; 1982: 61).

ASPECTS OF BIOLOGY

Records of larval stages in the NE Atlantic:

(a) First intermediate host

Nassarius reticulatus [?] St. Efflam, Côtes du Nord, Finistère, France. Richard (1971: 154; as Zoogonus sp.).

— [digestive gland] Roscoff, Finistère, France. Stunkard (1932: 339; as Cercariaeum reticulatum).

(b) Second intermediate host

Psammechinus miliaris [muscles and connective tissue of Aristotle's lantern] Wimereux region, Artois, France.

Stunkard (1941: 208). 
Stunkard (1941) believed that there might be a biological distinction between $Z$. rubellus in the north-eastern Atlantic and Mediterranean Sea and the form Z. lasius in the north-western Atlantic. He not only emphasized apparent differences in life-cycle, but pointed out that, according to Goldschmidt (1905), Z. rubellus (= mirus) had 10 chromosomes and the North American form had 12 according to Brooks (1930). Benazzi \& Benazzi Lentati (1976), however, stated that Goldschmidt's observations were disputed by Schreiner \& Schreiner (1908), Grégoire (1909) and Wassermann (1913), all of whom say $2 \mathrm{n}=12$ in Z. mirus. The differences that Stunkard (1941) detected in the life-cycle included the observation that, whereas at Wimereux in Northern France he found the metacercariae commonly in the sea-urchin (Psammechinus miliaris), he failed to find the cercariae in over 1200 specimens of Nassarius reticulatus from the same region, although he found Cercariaeum reticulatum at Roscoff. Earlier $(1933,1936,1938)$ Stunkard had completed the life-cycle of the North American form and had found that Nassarius obsoletus was the first intermediate host and the annelid Nereis virens the second intermediate host. In 1941 he failed to find Zoogonus metacercariae in nereids around Wimereux and in sea-urchins in Massachusetts. He was, however, able to experimentally infest the echinoid Arbacia punctulatus with the North American form. He considered the "data on Zoogonus are hard to interpret. In view of the lack of specificity in life-cycles of their trematodes, it is not impossible that a single species of Zoogonus employs different primary, secondary and definitive hosts on the two sides of the Atlantic Ocean'. The metacercaria of the North American form has since (Stunkard, 1972) been found in the limpet Acmaea intestinalis, indicating that a wide range of invertebrates serve as second intermediate hosts for this species. A number of minor morphological differences between the larval stages of the North American and European forms are mentioned by Stunkard (1941), but these do not appear to be sufficient to distinguish these forms as species in the absence of other evidence. We have been able to examine adult specimens of the North American form $Z$. lasius from the posterior intestine of Leiostomus xanthurus (Sciaenidae) (BM(NH) 1983.11.1.1-8) and Trinectes maculatus (Soleidae) (BM(NH) 1983.11.1.9.) from Lower Chesapeake Bay, Virginia, USA (collector: E. M. Burreson) and from Menidia menidia (Atherinidae) (BM(NH) 1985.1.16.2-3) from Sam Orr Pond, near St Andrews, New Brunswick, Canada (collector: R.A.B). Their dimensions are included on Table 1. There seems to be a consistent difference between these forms and $Z$. rubellus from the north-east Atlantic, in that the suckers are relatively distinctly smaller and the prepharynx longer and usually narrower. These features are so striking when comparing specimens (Figs 1,2) that it appears most prudent to consider $Z$. lasius distinct. It should also be noted that, despite a reasonable amount of collecting in the area, no Zoogonus specimens have been found in the Iceland/Greenland region which suggests that there is a discontinuity in the distribution of these forms. The work of Stunkard $(1938,1941)$ has shown that Cercariaeum lintoni Miller \& Northup, 1926 is the larval form of the American species, $Z$. lasius, and that $C$. reticulatum is likely to be identical to the European species, Z. rubellus.

The first intermediate host of $Z$. rubellus is, therefore, most probably Nassarius reticulatus. Cercariaeum reticulatum, as described by Stunkard (1932), is a tail-less xiphidiocercaria emanating from the digestive gland of the host. In 1941 Stunkard believed it to be a larval Zoogonus, although originally he pointed out its similarity to the larva of Diphterostomum brusinae. It differs from the $D$. brusinae cercaria, however, in that it lacks a very large ventral sucker with muscular lips and possesses a long prepharynx. In fact $C$. reticulatum is very similar to the larva of $Z$. lasius, also known as Cercariaeum lintoni, which has been described by Leidy (1891), Linton (1915), Miller \& Northup (1926), Africa (1930), Shaw (1933) and Stunkard (1938).

The host-parasite relationships of the larval stages of $Z$. lasius (often as $Z$. rubellus) are surprisingly well studied considering the rather small amount of work done on the adult form. A number of studies have been undertaken on the eastern coast of the USA which may be relevant to the biology of $Z$. rubellus in the north-eastern Atlantic. These studies have usually involved the first intermediate host, Nassarius obsoletus, a snail which is also regularly infested with a number of other digeneans. The sporocyst generations were described by Stunkard (1938) - rediae do not occur. The seasonal prevalence in N. obsoletus was studied on Rhode Island by Gambino (1959) and in North Carolina by McDaniel \& Coggins $(1971,1972)$. Gambino found that May saw the peak of infestation, and also found that the higher rate of infestation was to be found in the 
Table 1 Measurements of Zoogonus lasius

\begin{tabular}{|c|c|c|c|c|}
\hline Authority & Stunkard (1938) & & Present study & \\
\hline Name used & $\begin{array}{l}\text { Zoogonus } \\
\text { rubellus }\end{array}$ & & $\begin{array}{l}\text { Zoogonus } \\
\text { lasius }\end{array}$ & \\
\hline Host & $\begin{array}{l}4 \text { fish spp. } \\
\text { (3 expl) }\end{array}$ & $\begin{array}{l}\text { Leiostomus } \\
\text { xanthurus }\end{array}$ & $\begin{array}{l}\text { Trinectes } \\
\text { maculatus }\end{array}$ & $\begin{array}{l}\text { Menidia } \\
\text { menidia }\end{array}$ \\
\hline Locality & Massachusetts & Chesapeake Bay & Chesapeake Bay & New Brunswick \\
\hline Length (mm) & $0 \cdot 7-1 \cdot 2$ & $0.94-1.05$ & 0.84 & $0 \cdot 76-1 \cdot 2$ \\
\hline Breadth $(\mathrm{mm})$ & $0 \cdot 18-0 \cdot 28$ & $0 \cdot 15-0 \cdot 18$ & $0 \cdot 18$ & $0 \cdot 20-0 \cdot 26$ \\
\hline $\begin{array}{l}\text { Length : forebody } \\
\text { ratio }\end{array}$ & - & $1: 0 \cdot 37-0 \cdot 42$ & $1: 0 \cdot 35$ & $1: 0 \cdot 22-0 \cdot 26$ \\
\hline Oral sucker $(\mathrm{mm})$ & $\begin{array}{c}0.07-0.08 \\
\text { diam. }\end{array}$ & $\begin{array}{r}0.04-0.06 \times \\
0.05-0.06\end{array}$ & $0.08 \times 0.07$ & $\begin{array}{c}0 \cdot 07-0 \cdot 08 \times \\
0.08\end{array}$ \\
\hline $\begin{array}{l}\text { Ventral sucker } \\
(\mathrm{mm})\end{array}$ & $\begin{array}{l}0.075-0.085 \\
\text { diam. }\end{array}$ & $\begin{array}{r}0.06-0.08 \times \\
0.07-0.08\end{array}$ & $0.09 \times 0.08$ & $\begin{array}{r}0.09-0 \cdot 10 \times \\
0 \cdot 09-0 \cdot 12\end{array}$ \\
\hline Sucker-ratio & - & $1: 1 \cdot 3-1 \cdot 4$ & $1: 1 \cdot 1$ & $1: 1 \cdot 1-1 \cdot 5$ \\
\hline Prepharynx (mm) & - & $0 \cdot 25-0 \cdot 31$ & $0 \cdot 17$ & $0 \cdot 11-0 \cdot 12$ \\
\hline Pharynx $(\mathrm{mm})$ & $\begin{array}{c}0.04-0.06 \\
\text { diam. }\end{array}$ & $\begin{array}{r}0.03-0.05 \times x \\
0.04-0.05\end{array}$ & 0.06 diam. & $\begin{array}{l}0.06 \times \\
0.04-0.05\end{array}$ \\
\hline Oesophagus (mm) & - & $0.17-0.24$ & $0 \cdot 17$ & $?$ \\
\hline Cirrus-sac (mm) & - & $\begin{array}{r}0.15-0.20 \times \\
0.04-0.05\end{array}$ & $0.17 \times 0.04$ & $0.16 \times 0.05$ \\
\hline Testes (mm) & $\begin{array}{l}0.032-0.073 \\
\text { diam. }\end{array}$ & $\begin{array}{c}0.12-0 \cdot 13 \times \\
0.09\end{array}$ & $\begin{array}{l}0.08 \times \\
0.05-0.06\end{array}$ & $\begin{array}{r}0 \cdot 10-0 \cdot 11 \times \\
0.07-0.08\end{array}$ \\
\hline Ovary (mm) & $0.04-0.06$ & 0.08 diam. & $0.07 \times 0.06$ & \\
\hline Miracidium $(\mu \mathrm{m})$ & $\begin{array}{l}90-120 \times 36-45 \\
\text { (fixed) } \\
100-130 \times 45-56 \\
\text { (alive) }\end{array}$ & $94-128 \times 40-47$ & $102-137 \times 50-59$ & $110-120 \times 45$ \\
\hline
\end{tabular}

high-tide zone. Sindermann (1960) reported that $Z$. lasius (as Z. rubellus), along with other larval digeneans, retarded or inhibited the offshore migration of the snail host, thus contributing to the relatively high inshore prevalence in autumn, and leaving the snails in a progressively more unfavourable environment, the high-tide zone, in winter. Laboratory experiments on the locomotion of infested and uninfested N. obsoletus by Stambaugh \& McDermott (1969) supplemented Sindermann's findings. Schaefer, Milch \& Levin (1970) found that a Zoogonus infection 'decreases the ability of the snail host to withstand dessication'. This may have a serious effect on the parasitized snails which are 'reluctant' to undergo their seasonal migration offshore. Further effects of $Z$. lasius infestation on $N$. obsoletus were investigated by Vernberg \& Vernberg (1963, 1967) who found that the snail's resistance to thermal stress was reduced, and later (1971) they showed that $Z$. lasius metacercariae had a similar effect on their annelid host, Leonereis culverti. Riel (1975), on the other hand, found that infected $N$. obsoletus survived higher temperatures than uninfested and explained the discrepancy with earlier findings by suggesting seasonal differences. $\mathrm{He}$ also found that infested snails survived longest in distilled water. The cytochrome-c-oxydase activity and fatty acid composition of $N$. obsoletus digestive gland tissue were found by Vernberg (1969) and Lunetta \& Vernberg (1971), respectively, to be altered by Z. lasius infestation, and it was suggested that this effect played a role in the lowered resistance to thermal stress reported at that time. Protein content in infested snail digestive gland decreased sharply (by $50 \%$ ) according to Schilansky, Levin \& Fried (1977). A further result of Z. lasius infestation of N. obsoletus 
is, according to Cheng, Sullivan \& Harris (1973), 'direct chemical castration' and this prompted these authors to suggest that $Z$. lasius could represent a possible biological control agent of Austrobilharzia variglandis (Miller \& Northup, 1926), the cause of 'swimmer's itch', the larvae of which also parasitize $N$. obsoletus.

Studies of the various larval digeneans found in $N$. obsoletus have shown that the thermal toleration of various larval parasites and the host are unconnected (Vernberg \& Vernberg, 1965, 1966, 1968), and, therefore, 'each species of parasite retains its own physiological integrity' (Vernberg \& Vernberg, 1965). 'The response of the larvae sharing the same thermal environment differs so greatly that one can conclude that this is a genetically predetermined response which is not markedly influenced by the thermal environment of the intermediate host' (Vernberg \& Vernberg, 1966). Vernberg $(1961 a, b)$ contrasted the temperature tolerance of the cercariae of Himasthla quissetensis (Miller \& Northup, 1926), which has gulls as its final host, and Z. lasius, and found that while $Z$. lasius cercariae cannot survive temperatures above $39^{\circ} \mathrm{C}, \mathrm{H}$. quissetensis cercariae can tolerate $41^{\circ} \mathrm{C}$ for prolonged periods. Vernberg correlated these findings with the body temperature of the definitive hosts of these species and suggested (1968) that this 'could well reflect a physiological preadaptation'.

$Z$. lasius was found to be more frequently involved in double infections than any of the other six relatively common digenean parasites of $N$. obsoletus. Vernberg, Vernberg \& Beckerdite (1974) found that 12 out of 14 double infestations involved Z. lasius, and De Coursey \& Vernberg (1974) found that $57 \%$ of the double infestations of Z. lasius were with Lepocreadium setiferoides (Miller \& Northup, 1926). Both species tend to shed cercariae in daylight, and $L$. setiferoides tends to suppress the shedding of $Z$. lasius. McDaniel \& Coggins $(1971,1972)$, on the other hand, could not find more than one species shed by any individual snail. Although primarily found in the digestive gland, Z. lasius was found by De Coursey \& Vernberg (1974) to spread to the gonadal area and the hepatopancreas in heavy infestations.

In Europe the metacercaria of Z. rubellus occurs in the connective tissue and muscles of Aristotle's lantern of sea-urchins. Timon-David $(1933,1934,1937 a, 1938)$ records it in Paracentrotus lividus, Sphaerechinus granularis and Arbacia aequituberculata in the Mediterranean, and experimental infestations (Timon-David, 1937a, 1938) of Blennius gattorugine yielded immature worms after 45 days. Stunkard (1941) described the metacercaria from the sea-urchin Psammechinus miliaris in northern Brittany. The metacercariae of $Z$. lasius in the USA are reported from the polychaetes Nereis virens (by Stunkard, 1938) and Leonereis culverti (by Vernberg \& Vernberg, 1971) and the limpet Acmaea intestinalis (by Stunkard, 1972).

The distribution of $Z$. rubellus includes, in addition to the north-eastern Atlantic and the Mediterranean Sea, the Red Sea and the west coast of Africa. A wide range of teleosts have been recorded as definitive hosts; apparently Perciformes and Pleuronectiformes are the major groups implicated, but records from Clupeiformes and Zeiformes have been made. The records from Trachurus trachurus need confirmation as this fish does not prey on the known intermediate hosts of $Z$. rubellus.

PREVIOUS DESCRIPTIONS. Olsson (1868: 40; as D. rubellum); Looss (1901: 439; as Z. mirus); Goldschmidt (1902: 870; 1905: 607; as Z. mirus); Odhner (1902: 59; 1911a: 245); Nicoll (1909a: 17).

DESCRIPTION (Figs 1, 2A,B). Twenty-nine whole-mounts and ten sets of serial sections were examined. The largest, most highly developed worms are from Anarhichas lupus (Figs 1A, 2A,B). Measurements of this species are included in Table 2 . The worms are very small and bear annular rows of very small tegumental spines. These reach posteriorly only as far as about the middle of the hindbody, and may not always be apparent at all. The subterminal oral sucker is more or less globular and leads to a distinct wide prepharynx and to an oval pharynx situated in about the mid-forebody. This gives rise to a long, wide oesophagus which is lined with tegument. It divides level with the posterior part of the ventral sucker or a little more posteriorly. There is a short, narrow region lined with tegument which leads to the wide, short, saccular caeca which are lined with epithelium. These caeca do not reach far into the posterior half of the hindbody, but as the hindbody apparently develops allometrically, this relationship varies with age. The ventral sucker, 

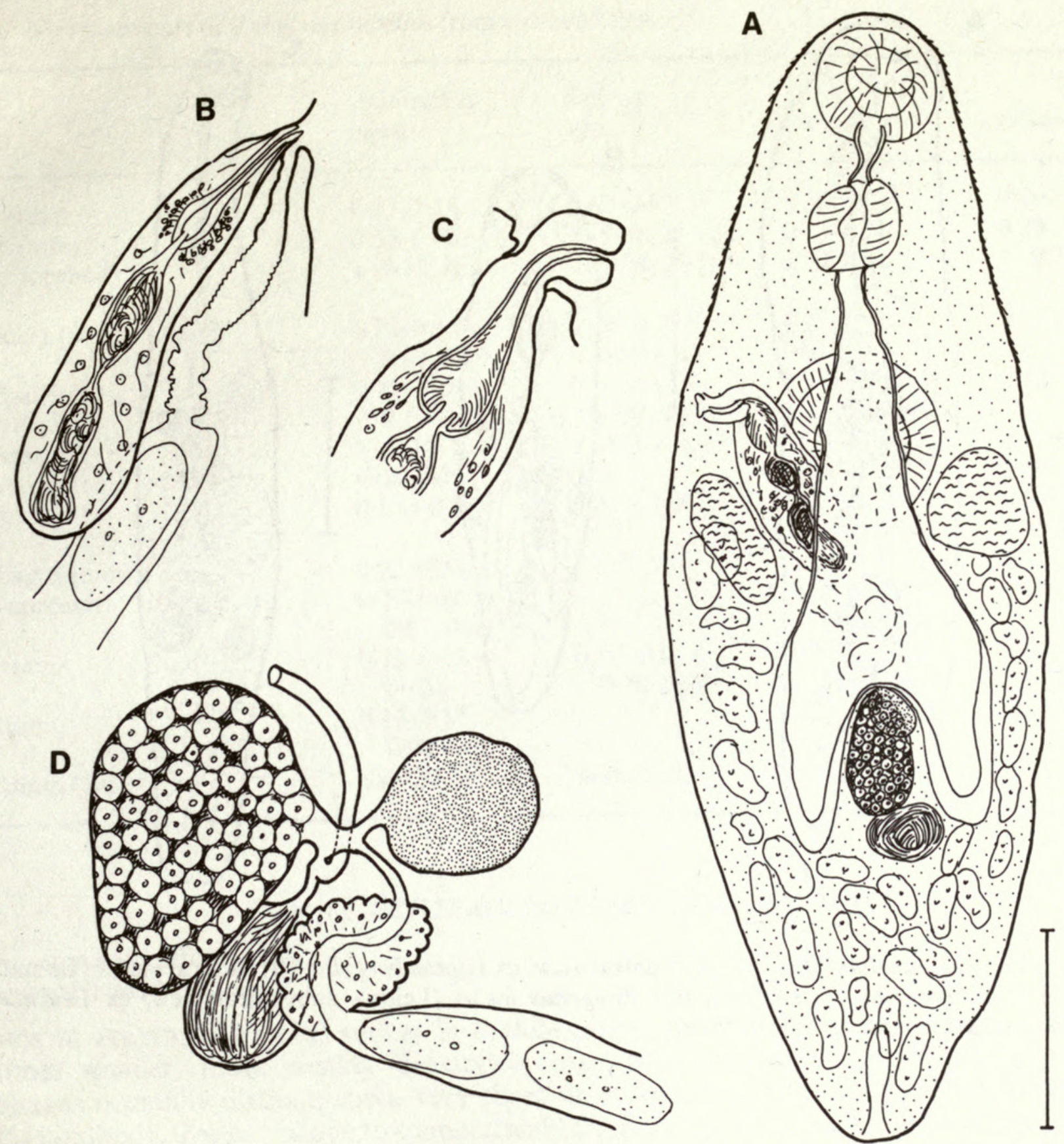

Fig. 1 Zoogonus rubellus (Olsson). (A) Dorsal view, ex Anarhichas lupus; (B) Terminal genitalia; (C) Everted cirrus; (D) Proximal female genitalia. Scale bar: A $0.2 \mathrm{~mm}$.

which lies within the anterior half of the body, is similar in size to the oral sucker or may be slightly larger or smaller.

The excretory pore is terminal and leads into a short sac-like vesicle, which does not normally reach as far forward as the gonads.

The large oval testes lie symmetrically just posterior to the ventral sucker. It was not possible to fully trace the vasa efferentia, but there is, apparently, a very short vas deferens which divides close to the cirrus-sac. This latter organ is elongate and reaches well into the hindbody to about the level of the posterior margin of the testes and is often twisted distally. It contains a bipartite seminal vesicle which may be narrow (Fig. 1B) or bulbous (Fig. 2A), a short, vesicular pars prostatica and a narrow ejaculatory duct which is, apparently, not lined with spines. The remainder of the cirrus-sac is filled with gland-cells and connective tissue. A small genital atrium receives the ejaculatory duct beside the metraterm. The genital pore lies almost marginally at about the level of the middle of the ventral sucker and on the left side of the body. The cirrus is often everted a short way through the genital atrium (Fig. 1C). 

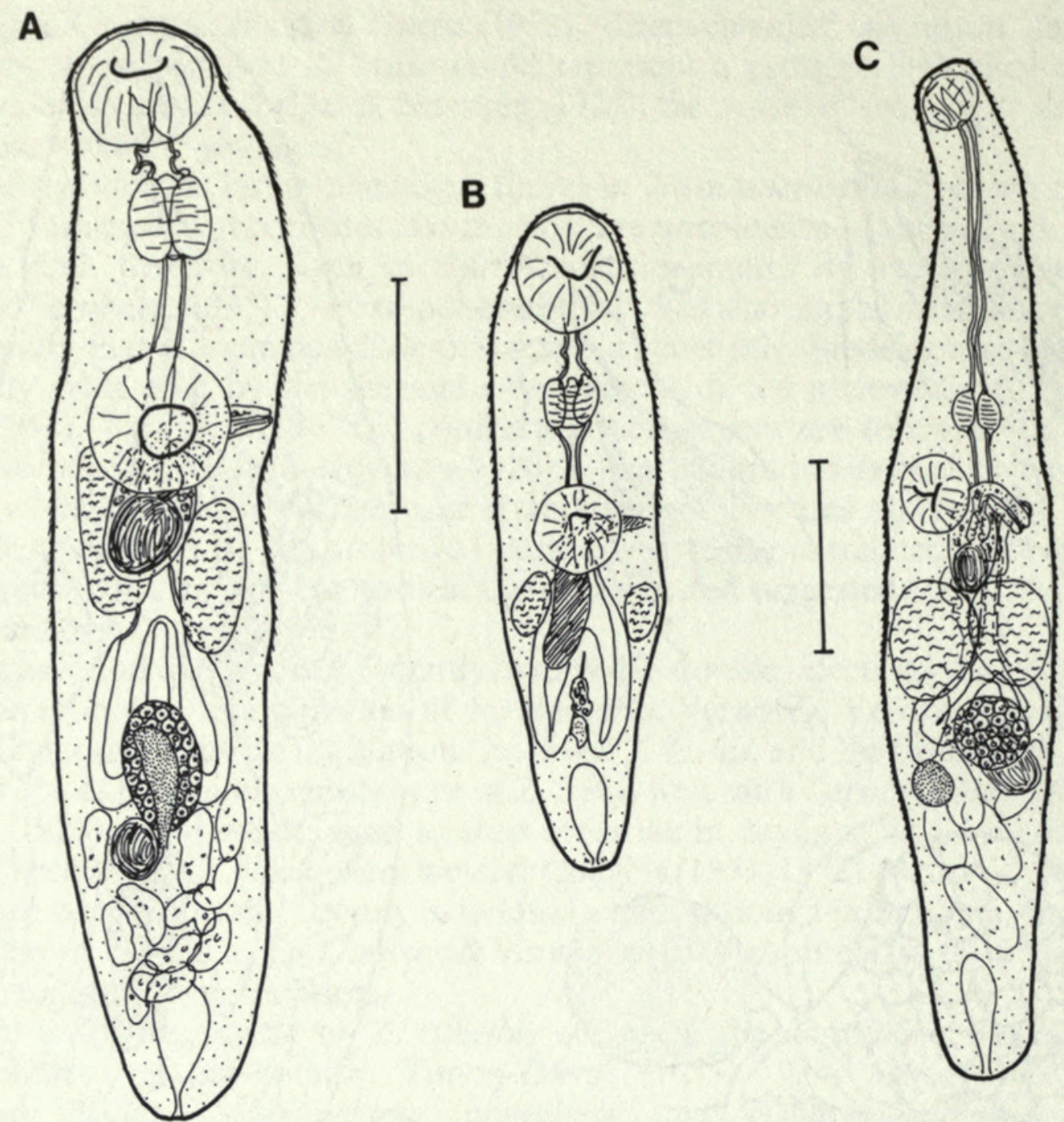

Fig. 2 Zoogonus rubellus (Olsson). (A) Ventral view, ex Labrus bergylta; (B) Ventral view of immature worm from Pleuronectes platessa; (C) Zoogonus lasius (Leidy), subventral view, ex Leiostomus xanthurus. Scale bars: A, B, C 0.2 mm.

The ovary, canalicular seminal receptacle and single, subglobular vitellarium are situated close together in the area between the short caeca. Unfortunately the ten sets of sectioned specimens do not clearly show the ducts which connect these organs, or Laurer's canal, although it appears that this latter organ opens on the dorsal surface at about the level of the ovary (Fig. 1D). The ovary lies more or less in the median line close to the dorsal surface with the seminal receptacle ventro-dextral and the vitellarium sinistral. The vitellarium is in the form of a small, subspherical body. The uterus fills the hindbody posterior to the gonads and passes forward to form a short, narrow, muscular metraterm apparently lined with fine spines. The uterus contains miracidia apparently surrounded by an egg-capsule, which may vary in thickness but is never tanned, being membranous. The eggs may be elongate in the uterus or packed closely and flattened at the ends. Thus measurements of eggs in utero are of limited taxonomic value.

Discussion. The validity of $Z$. rubellus and Z. lasius was discussed on p. 130. Z. mirus, the original type of the genus was considered a synonym of $Z$. rubellus by Nicoll (1909) and no one has seriously questioned this conclusion. Stunkard (1941) believed that 'at present there is no basis for a positive distinction between species of Zoögonus from the North Sea [i.e. rubellus] and the Mediterranean [i.e. mirus] ...' We agree with this, there being no morphological or other features which have been raised to substantiate the validity of $Z$. mirus. 
Table 2 Measurements of Zoogonus rubellus from various fishes

\begin{tabular}{|c|c|c|c|c|}
\hline Host & $\begin{array}{l}\text { Anarhichas } \\
\text { lupus }\end{array}$ & $\begin{array}{l}\text { Labrus } \\
\text { spp. }\end{array}$ & Flatfish & Mean \\
\hline Length (mm) & $0 \cdot 87-1 \cdot 16$ & $0.62-0.93$ & $0 \cdot 50-1 \cdot 2$ & $0 \cdot 80$ \\
\hline Breadth $(\mathrm{mm})$ & $0 \cdot 35-0.40$ & $0.19-0.32$ & $0.15-0.56$ & $0 \cdot 29$ \\
\hline $\begin{array}{l}\text { Length : forebody } \\
\text { ratio }\end{array}$ & $1: 0 \cdot 30-0.345$ & $1: 0 \cdot 30-0.35$ & $1: 0.34-0.48$ & $1: 0 \cdot 35$ \\
\hline Oral sucker (mm) & $\begin{array}{r}0 \cdot 12-0 \cdot 14 \times \\
0 \cdot 12-0 \cdot 14\end{array}$ & $\begin{array}{r}0 \cdot 08-0 \cdot 10 \times \\
0 \cdot 10-0 \cdot 12\end{array}$ & $\begin{array}{r}0.09-0.14 \times \\
0.09-0.18\end{array}$ & $0.11 \times 0.12$ \\
\hline $\begin{array}{l}\text { Ventral sucker } \\
(\mathrm{mm})\end{array}$ & $\begin{array}{r}0 \cdot 15-0 \cdot 18 \times \\
0 \cdot 15-0 \cdot 19\end{array}$ & $\begin{array}{r}0 \cdot 10-0 \cdot 12 \times \\
0 \cdot 09-0.13\end{array}$ & $\begin{array}{r}0.075-0.20 \times \\
0.075-0.22\end{array}$ & $0.13 \times 0.13$ \\
\hline Sucker-ratio & $1: 1 \cdot 24-1 \cdot 36$ & $1: 0 \cdot 9-1 \cdot 2$ & $1: 0.9-1 \cdot 4$ & $1: 1 \cdot 12$ \\
\hline Prepharynx (mm) & $0.04-0.05$ & 0.05 & $0.045-0.11$ & 0.06 \\
\hline Pharynx $(\mathrm{mm})$ & $0 \cdot 10 \times 0 \cdot 10$ & $0.07 \times 0.08$ & $\begin{array}{c}0.05-0.10 \times \\
0.045-0.14\end{array}$ & $\begin{array}{r}0.076 \times \\
0.086\end{array}$ \\
\hline Oesophagus (mm) & $0.22-0.37$ & - & $0.06-0.22$ & $0 \cdot 20$ \\
\hline Cirrus-sac (mm) & $\begin{array}{r}0 \cdot 20-0.24 \times \\
0.07-0.09\end{array}$ & - & $\begin{array}{r}0 \cdot 26-0 \cdot 32 \times \\
0 \cdot 08-0 \cdot 10\end{array}$ & $0.26 \times 0.08$ \\
\hline Testes (mm) & $\begin{array}{c}0 \cdot 13-0 \cdot 15 \times \\
0 \cdot 10\end{array}$ & $\begin{array}{r}0 \cdot 10-0 \cdot 11 \times \\
0 \cdot 10-0 \cdot 12\end{array}$ & $\begin{array}{c}0.07-0.12 \times \\
0 \cdot 045-0.11\end{array}$ & $0.11 \times 0.09$ \\
\hline Ovary (mm) & $\begin{array}{r}0 \cdot 13-0 \cdot 17 \times \\
0.08-0.12\end{array}$ & - & - & $0.15 \times 0.09$ \\
\hline Miracidium $(\mu \mathrm{m})$ & $85-135 \times 47-55$ & immature & immature & \\
\hline
\end{tabular}

Genus DIPHTEROSTOMUM Stossich, 1903

Diphtherostomum Stafford, 1905.

Zoonogenus Nicoll, 1912.

DiAgNOSTIC FEATURES. Ventral sucker in middle or posterior of body, often large, muscular, sometimes smaller, more weakly developed; may bear muscular lips. Prepharynx short. Oesophagus normally distinct; caeca very short to short; terminating in posterior forebody to anterior hindbody. Testes oblique to symmetrical, in region of ventral sucker. Cirrus-sac variable. Seminal vesicle bipartite. Pars prostatica vesicular. Genital atrium distinct. Genital pore marginal to submarginal, in forebody; usually sinistral. Ovary subglobular, close to testes. Vitellarium consists of two subequal masses. Miracidium surrounded by membranous capsule or very thin shell. Excretory pore terminal, vesicle small, saccular. Sporocysts in.gastropods. Tail-less xiphidiocercaria. Metacercariae encyst in invertebrates, occasionally on plants and sedentary animals. Adults in marine teleosts and elasmobranchs.

\section{Key to Diphterostomum spp. found in the north-east Atlantic}

1. Ventral sucker with muscular lips

- Ventral sucker lacking muscular lips .

2 Sucker ratio $1:>2 \cdot 3$; parasite of teleosts.

- Sucker ratio $1:<2 \cdot 3$; parasite of elasmobranchs
D. brusinae (Stossich, 1888) (p. 135)

.D. vividum (Nicoll, 1912) (p. 144)

D. betencourti (Monticelli, 1893) (p. 142)

\section{Diphterostomum brusinae (Stossich, 1888) Stossich, 1903}

Distoma brusinae Stossich, 1888.

Pleurogenes brusinae (Stossich, 1888) Stossich, 1899.

Distoma (Brachycaecum) brusinae (Stossich, 1888) Barbagallo \& Drago, 1903.

(?) Sporocystis sp. de Filippi, 1854. 
(?) Distomum buccini mutabilis de Filippi, 1855.

(?) Cercaria (Acanthocephala) buccini mutabilis (de Filippi, 1855) Diesing, 1858.

(?) Agamodistomum buccini mutabilis (de Filippi, 1855) Parona, 1912.

Cercaria inconstans Sinitsin, 1911.

Adolescaria inconstans Sinitsin, 1911.

(?) Cercaria crispata Pelseneer, 1906.

Diphterostomum sargus annularis Vlasenko, 1931.

Diphterostomum spari Yamaguti, 1938.

Diphterostomum macrosaccum Montgomery, 1957.

Diphterostomum anisotremi Nahhas \& Cable, 1964.

Diphterostomum tropicum Durio \& Manter, 1963.

Diphterostomum israelense Fischthal, 1980.

TYPE-HOST AND LOCALITY. Oblada melanura, Trieste, Italy.

\section{RECORDS}

(i) Material studied

(a) From the NE Atlantic

None.

(b) From elsewhere

Diplodus annularis [rectum, small intestine] Split, Yugoslavia (May, 1968), material lent by O. Sey (see Sey, 1970); and (Sept. 1975). BM(NH) 1982.4.21.1-2.

Lethrinus sp. [?] New Caledonia. Holotype of D. tropicum. USNM 63308.

Sillago analis [rectum] Deception Bay, Queensland, Australia. (Jan. 1981). Collector: G. Berry. BM(NH) 1982.12.22.38.

Sillago maculata [rectum] Deception Bay, Queensland, Australia. (Sept. 1980, 1981). Collector: G. Berry. $\mathrm{BM}(\mathrm{NH})$ 1982.12.22.14-37.

Symphodus tinca [rectum] Split, Yugoslavia. (Sept. 1975). BM(NH) 1982.4.21.3-12.

(ii) NE Atlantic records from the literature

Blennius ocellaris [intestine] Roscoff, Finistère, France. Sproston (1939: 40).

(?) Diplodus vulgaris [?] Oveido, Spain. Martinez Fernandez, in Cordero del Campillo (1975: 81; as D. sp., not described).

\section{ASPECTS OF BIOLOGY}

Records of larval stages in the NE Atlantic:

(a) First intermediate host

(?) Natica alderi [?] Boulogne, France. Pelseneer (1906: 171; as Cercaria crispata).

(?) Nassarius reticulatus [?] St Efflam, Finistère, France. Richard (1971: 151; as D. sp.).

(b) Second intermediate host

None.

Richard (1971) described the chaetotaxy of the cercaria she considered Diphterostomum sp. and Bayssade-Dufour \& Maillard (1974), also using chaetotaxy, compared it with the cercariae of $D$. brusinae from Nassa mutabilis in the Mediterranean Sea. They concluded that Richard's cercaria belonged to the same genus, but did not comment as to whether they might be conspecific. Palombi (1930) also found the daughter-sporocyst in Nassa mutabilis in the Mediterranean. He found the sporocysts to contain about 20 cercariae in various stages of development. The cercaria itself is a tail-less xiphidiocercaria, without eyespots, and bears a prominant ventral sucker with the characteristic muscular lips. In $N$. mutabilis the metacercariae develop within the daughtersporocysts and, therefore, this snail serves as both first and second intermediate hosts. On being fed to Blennius gattorugine, Crenilabrus pavo and Sargus vulgaris by Palombi, metacercariae developed to ovigerous adults in 40 days, the entire life-cycle requiring about six months. Other reports of the life-cycle (Dolgikh, 1965a,b, 1966a,b, 1968, 1970; Prévot, 1966; Zaika, 1966; Dolgikh \& Naidenova, 1967; Gaevskaja, 1972; Zdun \& Ignatyev, 1980a,b) suggest that it is rather variable and that a number of different types of organisms can be utilized as second intermediate host. Prévot 
(1966) described a metacercaria from the crinoid Antedon mediterranea, and Zaika (1966) described a metacercaria similar to D. brusinae in the cephalochordate Branchiostoma lanceolatus. Dolgikh \& Naidenova (1967) and other workers in the Black Sea region discovered the cercaria ('Cercaria inconstans') from Nassa reticulata and Cyclonassa kamyschiensis. In addition to encysting within the daughter sporocyst in the gastropod and passing to lamellibranch second intermediate hosts (Venus, Pitar, Gouldia, Spisula, Modiolus, Chamelea, Parvicardium) to encyst, the cercariae may also encyst on plants, sponges and hydroids. This flexibility and variability of the life-cycle is reflected in considerable morphological variability in the adult.

The adult is normally to be found in the posterior intestine and rectum of perciform teleosts, notably of the families Sparidae, Gobiidae, Labridae, Pomadasyidae and Blenniidae. Most records are from the Mediterranean and Black Seas, with occasional reports from the north Atlantic, Caribbean Sea and Gulf of Mexico, Arabian Sea and North Pacific Ocean, Queensland (Australia), New Zealand, New Caledonia and south-west Atlantic.

Previous DeSCRIPTIONS. Stossich (1888: 99; 1889: 25); Looss (1901: 399); Palombi (1930: 111); Vlasenko (1931: 103; as D. sargus annularis); Yamaguti (1934: 400; 1938: 92; as D. spari); TimonDavid (1937b: 3); Montgomery (1957: 16; as D. macrosaccum); Ergens (1960: 80; as D. spari); Nahhas \& Cable (1964: 200; as D. anisotremi); Brinkmann (1967: 6); Naidenova (1967: 488); Durio \& Manter (1968: 152; as D. tropicum); Fischthal \& Thomas (1968: 139; As D. anisotremi); Fischthal (1980: 14; as D. israelense); Amato (1983: 692; as D. anisotremi).

DESCRIPTION (Figs 3a-c, 4, 5). Five whole-mounts from Diplodus annularus and 11 whole-mounts and two sets of serial sections from Symphodus tinca were studied along with eight whole-mounts from Sillago maculata, three whole-mounts from Sillago analis and the holotype of D. tropicum. While much of the morphology of these worms from all hosts is similar, striking differences in the structure of the cirrus-sac will be described below. The measurements of this worm are given in Table 3. The worms are elongate oval (Figs 4A, 5), bearing annular rows of acuminate tegumental spines (Fig. 3A) reaching posteriorly to the region of the ventral sucker. The subterminal to terminal (Fig. 5) oral sucker leads, via a short prepharynx, into a small, globular pharynx. This, in turn, leads to a distinct, long, oesophagus which bifurcates in the posterior forebody. The caeca are short, and somewhat saccular, overlapping the ventral sucker slightly or to about its middle. The large ventral sucker lies mainly in the posterior half of the body. It is strongly muscular and has protruding lamellar muscular anterior and posterior lips (Fig. 3b,c).

The excretory pore is terminal and leads via a short, narrow duct into a small, globular vesicle.

The testes, which are often surrounded by eggs and therefore not easily seen, lie obliquely or symmetrically either side of the proximal female complex and often overlap the posterior border of the ventral sucker. They are oval, normally slightly smaller than the ovary and may lie contiguous to the vitelline masses. The vas deferens was not seen. Two types of cirrus-sac were seen:

(1) In Diplodus annularis the cirrus-sac is short, straight or slightly curved and slants posteriorly at an acute angle (Fig. 4C). The bipartite seminal vesicle has a larger proximal section and leads into a vesicular pars prostatica lined with globule-like anuclear bodies. Numerous glandular prostatic cells surround the pars prostatica and the straight ejaculatory duct and tend to obscure their details.

(2) In Symphodus tinca and Sillago spp. the cirrus-sac is long and strongly reflexed and overlaps the ventral sucker to a much greater degree than is seen in the specimens from D. annularis (Fig. 4B). The bipartite seminal vesicle has subequal, globular portions and leads to a long pars prostatica which is particularly wide proximally. It is lined with globule-like anuclear bodies or villous filaments. It apparently reaches almost to the distal extremity of the cirrus-sac where it becomes a short, narrow ejaculatory duct which could not be precisely delineated. The cirrus-sac also contains numerous gland-cells.

In both cases the ejaculatory duct opens into a shallow genital atrium on the left margin of about the middle of the forebody.

The subglobular ovary lies dorsally to the posterior half of the ventral sucker in about the median line or slightly displaced to the right. The oviduct passes posteriorly from the ovary and receives the common viteline duct and the duct from both Laurer's canal and the seminal receptacle before 

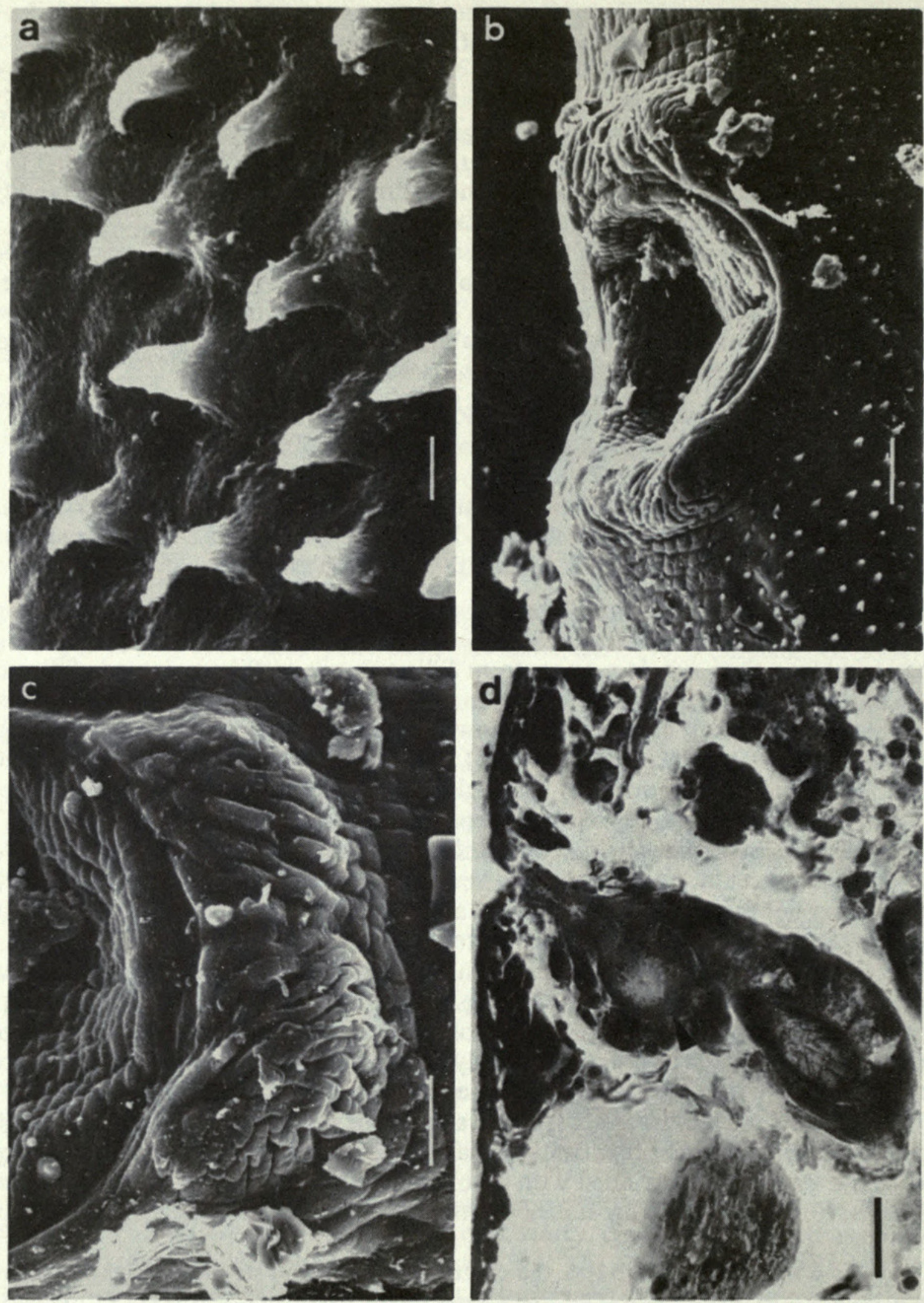

Fig. 3 Diphterostomum brusinae (Stossich), ex Symphodus tinca. (a) Tegumental spines in ventral forebody; (b) Lateral view of ventral sucker opening and lips; (c) Ventral sucker lip; (d) Zoogonoides viviparus (Olsson), photomicrograph of section showing atrial sac (arrowed). Scale bars: a $2 \mu \mathrm{m}, \mathrm{b}$ $20 \mu \mathrm{m}, \mathrm{c} 10 \mu \mathrm{m}, \mathrm{d} 30 \mu \mathrm{m}$.

entering Mehlis' gland. The small, sac-like, canalicular seminal receptacle is connected to the dorsal surface by a convoluted Laurer's canal which opens dorsally to one of the testes (Fig. 4D). The uterus, containing numerous eggs, fills much of the hindbody. The egg-capsules are very thin and in fixed specimens the eggs may appear to vary in size according to the medium in which they are mounted. In some preparations the egg-capsule appears completely membranous while in 

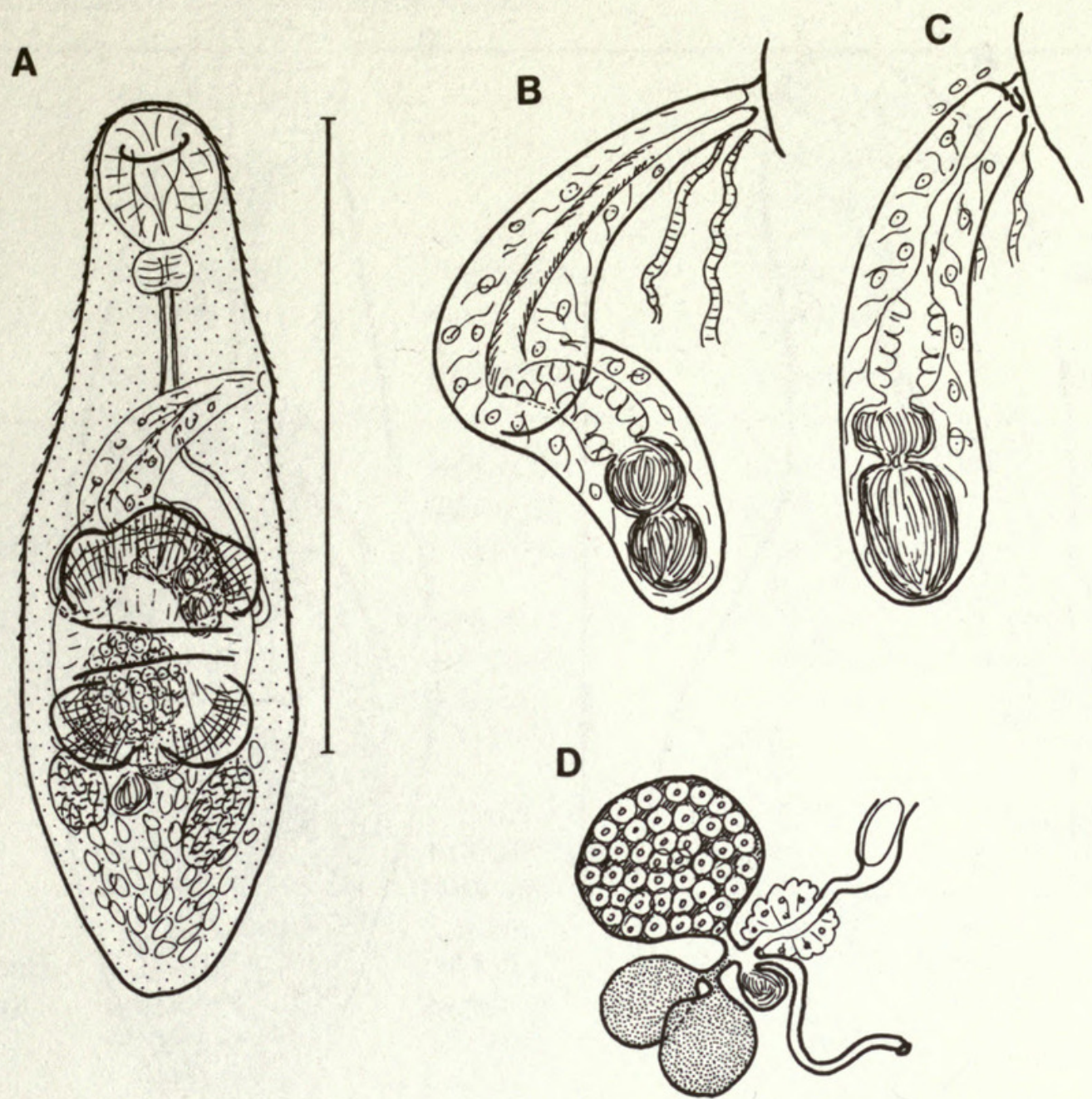

Fig. 4 Diphterostomum brusinae (Stossich). (A) ventral view, ex Symphodus tinca; (B) Cirrus-sac, ex S. tinca; (C) Cirrus-sac, ex Diplodus annularis; (D) Diagram of female proximal genitalia. Scale bar: A $0.5 \mathrm{~mm}$.

others it appears, under certain optical conditions, to be very lightly tanned. The metraterm is wide and muscular in the $S$. tinca and Sillago spp. specimens and is much less so in D. annularis. The vitellarium consists of two subglobular masses which lie either side of the ovary and are connected by a broad isthmus from which the common vitelline duct leads.

Discussion. The two distinct forms of terminal genitalia described above indicate that two species may be present. We have not, however, separated these forms for a number of reasons.

(1) The literature, in particular Palombi (1930), shows a wide variation in the form of the cirrus-sac. In Palombi's paper the cirrus-sac is figured in a variety of forms and the figure (table 1, fig. 1) which shows the longest, most reflexed cirrus-sac is of a specimen from Diplodus vulgaris, a fish congeneric with the host of our 'short cirrus-sac' form '(1)'. Some figures in the literature (e.g. Looss, 1901) show an intermediate form, but in our, admittedly limited, material there is no evidence of an intermediate form.

(2) Our studies of the species Pseudozoogonoides subaequiporus (see below, p. 147) indicate that the cirrus-sac varies in form in a similar way to that postulated here for D. brusinae.

(3) It is difficult to be certain from Stossich's (1889) figure to which form the type-specimens belong.

(4) This species has been recorded, as such, only once in the north-east Atlantic and we have no specimens from this region.

It is clear, however, that the structure of the cirrus-sac needs more careful study in this species. Further studies of material from the Mediterranean basin may show that more than one species has been confused, and this may account for the variation apparently found in the life-cycle. 

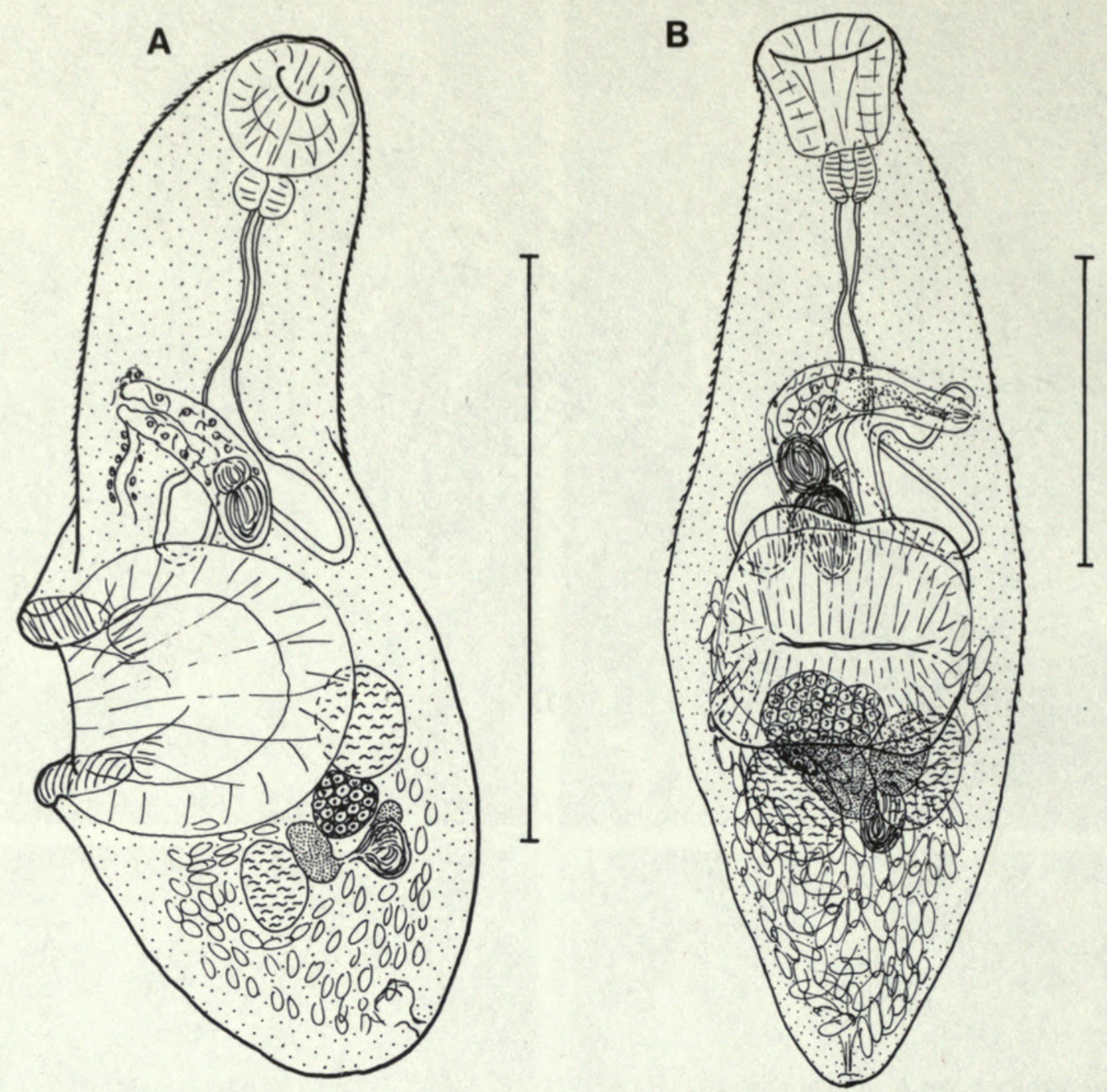

Fig. 5 Diphterostomum brusinae (Stossich). (A) Sublateral view, ex Diplodus annularis; (B) Ventral view, ex Sillago maculata. Scale bars: A $0.5 \mathrm{~mm}$, B $0.2 \mathrm{~mm}$.

The specimens from Sillago occasionally show a slightly infundibuliform terminal oral sucker (Fig. 5B), but not invariably. The eggs in these specimens also tend to be smaller than the Mediterranean form.

Diphterostomum sargus annularis Vlasenko, 1931, from Diplodus annularis in the Black Sea has been considered a synonym of Diphterostomum brusinae by Dolgikh \& Naidenova (1967), and this seems acceptable as no differences between it and the generalized form the $D$. brusinae which we describe can be found. This also applies to D. spari Yamaguti, 1938, of Ergens (1960), who described his form from Diplodus vulgaris off Albania. We are inclined to consider that Yamaguti's original single specimen of D. spari, from Sparus longispinus in Japan, belongs to D. brusinae. He distinguished this species on egg-size (about $60 \times 24 \mu \mathrm{m}$ ), but this single measurement indicates that he measured only one or a few eggs. The egg-capsule is very thin and we have found that specimens mounted in Canada balsam show an egg-size distinct from those mounted in glycerine jelly, so it appears that this character should be used with caution in this group. Published measurements of $D$. brusinae approach those quoted for $D$. spari.

Diphterostomum macrosaccum Montgomery, 1957, from the 'cardiac end of stomach' of Neoclinus uninotatus from California appears to be a typical example of the long cirrus-sac form of $D$. brusinae. The genital pore is said to be dorsal, but is close to the lateral margin and is not readily distinguishable from the lateral pore of $D$. brusinae. This is, therefore, the first record of $D$. brusinae from the western coast of the USA although it has previously been recorded in the north Pacific by Yamaguti $(1934,1938)$ from Japan.

Diphterostomum anisotremi Nahhas \& Cable, 1964, from pomadasyid fishes off Florida, Jamaica, Venezuela, southern Brazil and Ghana is herein considered a synonym of $D$. brusinae. 
Table 3 Measurements of Diphterostomum brusinae

\begin{tabular}{|c|c|c|c|c|}
\hline Authority & Fischtal (1980) & & Present study & \\
\hline Name used & $\begin{array}{l}\text { Diphterostomum } \\
\text { israelense }\end{array}$ & & $\begin{array}{l}\text { Diphterostomum } \\
\text { brusinae }\end{array}$ & \\
\hline Host & $\begin{array}{l}\text { Diplodus spp. } \\
\text { Saurida }\end{array}$ & $\begin{array}{l}\text { Crenilabrus } \\
\text { tinca }\end{array}$ & $\begin{array}{l}\text { Diplodus } \\
\text { annularis }\end{array}$ & Sillago spp. \\
\hline Locality & Israel & Yugoslavia & Yugoslavia & Queensland \\
\hline Length (mm) & $0 \cdot 73-1 \cdot 18$ & $0.63-0.81$ & $0.84-1 \cdot 0$ & $0.60-0.70$ \\
\hline Breadth (mm) & $0 \cdot 17-0 \cdot 26$ & $0 \cdot 21-0.28$ & $0 \cdot 27$ & $0 \cdot 15-0.24$ \\
\hline $\begin{array}{l}\text { Length : forebody } \\
\text { ratio }\end{array}$ & {$[1: 0 \cdot 53-0 \cdot 55]$} & $1: 0.48-0.53$ & $1: 0.43-0.52$ & $1: 0.35-0 \cdot 50$ \\
\hline Oral sucker (mm) & $\begin{array}{r}0.09-0.12 \times \\
0.09-0.13\end{array}$ & $\begin{array}{r}0 \cdot 10-0 \cdot 11 \times \\
0 \cdot 10-0 \cdot 12\end{array}$ & $\begin{array}{l}0.12 \times \\
0.09-0.12\end{array}$ & $\begin{array}{r}0.09-0.10 \times \\
0.06-0.09\end{array}$ \\
\hline $\begin{array}{l}\text { Ventral sucker } \\
\text { (mm) } \\
\text { Sucker-ratio }\end{array}$ & $\begin{array}{r}0.16-0.23 \times \\
0.14-0.20\end{array}$ & $\begin{array}{r}0.18-0.21 \times \\
0.15-0.18\end{array}$ & $0.18 \times 0.20$ & $\begin{array}{r}0.14-0.15 \times \\
0.13-0.17\end{array}$ \\
\hline $\begin{array}{l}\text { width } \\
\text { length }\end{array}$ & $\begin{array}{l}1: 1 \cdot 42-1 \cdot 61 \\
1: 1 \cdot 62-1.90\end{array}$ & $\begin{array}{l}1: 1 \cdot 50-1 \cdot 54 \\
1: 1 \cdot 62-2 \cdot 08\end{array}$ & $\begin{array}{l}1: 1 \cdot 67 \\
1: 1 \cdot 50-2 \cdot 34\end{array}$ & $1: 1 \cdot 4-2 \cdot 0$ \\
\hline Pharynx (mm) & $\begin{array}{r}0.034-0.048 \times \\
0.032-0.049\end{array}$ & $\begin{array}{c}0.04-0.05 \\
\text { diam. }\end{array}$ & $\begin{array}{l}0.04-0.05 \\
\text { diam. }\end{array}$ & $\begin{array}{r}0.04-0.05 \times \\
0.03-0.04\end{array}$ \\
\hline $\begin{array}{l}\text { Oesophagus (mm) } \\
\text { Cirrus-sac (mm) }\end{array}$ & $\begin{array}{l}0.22-0.35 \\
\text { crescent }\end{array}$ & $\begin{array}{l}0 \cdot 13-0 \cdot 17 \\
\text { recurved }\end{array}$ & $\begin{array}{l}0 \cdot 125-0 \cdot 25 \\
\text { straight }\end{array}$ & $0 \cdot 07-0 \cdot 11$ \\
\hline & $\begin{array}{l}0.20-0.30 \times \\
0.04-0.075\end{array}$ & $\begin{array}{r}0.16-0.20+ \\
0.14-0.15 \times \\
0.05-0.06\end{array}$ & $\begin{array}{r}0.15-0.20 \times \\
0.06-0.07\end{array}$ & $\begin{array}{r}0.15-0.24 \times \\
0.04-0.045\end{array}$ \\
\hline Testes (mm) & $\begin{array}{l}0.06-0.07 \times \\
0.085-0.11\end{array}$ & - & $\begin{array}{r}0.08-0.11 \times \\
0.06-0.08\end{array}$ & $\begin{array}{r}0.07-0.10 \times \\
0.04-0.06\end{array}$ \\
\hline Ovary (mm) & $\begin{array}{c}0.07-0.10 \times \\
0.07-0.09\end{array}$ & $\begin{array}{r}0.09-0 \cdot 10 \times \\
0.08-0.09\end{array}$ & $0.12 \times 0.09$ & $\begin{array}{c}0.04-0.06 \\
\text { diam. }\end{array}$ \\
\hline Eggs $(\mu \mathrm{m})$ & $33-44 \times 13-18$ & $30-45 \times 15-24$ & $35-39 \times 12-18$ & $28-31 \times 9-11$ \\
\hline
\end{tabular}

The sucker is obviously strongly muscular although the lips were not originally described, and in ihe specimen figured in the original description the sucker has taken up a lateral configuration which often happens in D. brusinae (see Fig. 5A). Amato's (1983) description, however, stressed the muscular 'flap-like' extensions of the ventral sucker. The sucker ratios quoted by Nahhas \& Cable (1964) and Amato (1983) are $1: 2-2 \cdot 35$ and $1: 2 \cdot 06-2 \cdot 47$, respectively, which appear to be slightly more than is usual for $D$. brusinae. Fischthal \& Thomas (1968) quoted the figures $1: 1 \cdot 46-2.0$ when recording this parasite from Pomadasys jubelini off Ghana. It should be noted that this fish in the south-east Atlantic has been recorded as a host of $D$. brusinae by Aleshkina (1979).

Diphterostomum tropicum Durio \& Manter, 1968, recorded from Lethrinus sp., New Caledonia, L. glyphodon, Queensland, Australia (Durio \& Manter, 1968) and Chrysophrys auratus, New Zealand (Korotaeva, 1975) is herein considered a synonym of D. brusinae. Examination of the holotype (USNM 63308) has shown that muscular lamellar lips are present on the ventral sucker, so the major point of difference reported by Durio \& Manter appears to be invalid. The other differentiating features invoked by Durio \& Manter do not appear to differ from those exhibited by D. brusinae as described above.

Diphterostomum israelense Fischthal, 1980, from Diplodus sargus, D. annularis and Saurida undosquamis from the Israeli coast of the Mediterranean, is not distinguishable from D. brusinae. The variations in this species which we described above comfortably encompass Fischthal's (1980) description, and D. annularis is one of the hosts from which our material was recovered. 
Diphterostomum betencourti (Monticelli, 1893) Odhner, 1911

Distomum betencourti Monticelli, 1893.

Pleurogenes betencourti (Monticelli, 1893) Stossich, 1899.

Distoma lutea van Beneden, 1871 nec von Baer, 1857.

Brachycoelium luteum (van Beneden, 1871) Giard, 1897.

Diphterostomum luteum (van Beneden, 1871) Stossich, 1903.

Distomum (Brachycoelium) luteum (van Beneden, 1871) Giard, 1907.

TYPE-HOST AND LOCALITY. Scyliorhinus caniculus, Belgian coast.

\section{RECORDS}

(i) Material studied

(a) From the NE Atlantic

Scyliorhinus caniculus [spiral intestine] Roscoff, Finistère, France (Sept. 1938). Collected by O. Nybelin. Lent by Goteborgs Naturhistoriska Museet.

Scyliorhinus stellaris [spiral intestine] Roscoff, Finistère, France (Sept. 1938). Collected by O. Nybelin. Lent by Goteborgs Naturhistoriska Museet.

(b) From elsewhere

None

(ii) NE Atlantic records from the literature

(?) Chelon labrosus [intestine] Ostende, Belgium. van Beneden (1871: 28; as Distoma luteum, 'Elles ressembles beaucoup à un Distoma que nous avons vu dans le Scillium canicula').

Scyliorhinus caniculus [intestine] Belgian coast. van Beneden (1871: 3; as Distoma lutea).

- [rectum] Saint Serran, Ille-et-Vilaine, France. Dollfus (1937: 60).

- [rectum] Roscoff, Finistère, France. Dollfus (1937: 60).

- [spiral intestine] Roscoff, Finistère, France. Sproston (1939: 37).

Scyliorhinus stellaris [?] Wimereux, Artois, France. Monticelli (1890: 424; as Distomum luteum); Odhner (1911a: 242).

- [stomach] Boulogne, Artois, France. Dollfus (1937: 61).

AsPeCts of BIOLOGY. This species, along with Pseudozoogonoides sp. innom., is among the few zoogonids described from elasmobranchs. In contrast to the third zoogonid species from elasmobranchs, Steganoderma (Steganoderma) formosum, reported as an accidental parasite of Squalus acanthias and Raja naevus by Myers (1959) and Threlfall (1969), this species appears to inhabit these dogfish as its preferred hosts. The above records are, we believe, a complete list of the records of this species. It is, therefore, reported from a very restricted area.

No details of the life-history are known.

PREVIOUS DESCRIPTIONS. van Beneden (1871: plate IV fig. 9; as Distoma lutea); Monticelli (1890: 424; as Distomum luteum); Stossich (1903: 193; as Distomum betencourti); Odhner (1911a: 242).

DESCRIPTION (Fig. 6). Five specimens from S. caniculus and two from $S$. stellaris were examined in flattened whole-mount preparations (Fig. 6). The measurements are given on Table 4. The body is oval in outline and bears spines back to about the level of the ventral sucker. The subglobular oral sucker opens subterminally, and leads via a small prepharynx, or sometimes apparently directly, into a small globular pharynx. The distinct oesophagus varies considerably in length and bifurcates in the posterior half of the forebody, giving rise to short caeca which reach to about the middle of the ventral sucker, abutting the anterior edge of the testes. They are normally bulbous, but may appear narrow. The ventral sucker is larger than the oral, but does not bear the conspicuous muscular lips of $D$. brusinae. It is transversely elongate, lying in the posterior half of the body.

The excretory pore is terminal. The details of the vesicle were not seen, but in some worms a large, bulbous vesicle can be seen posteriorly to the uterine field.

The oval testes usually lie with their long axis orientated longitudinally in a symmetrical to oblique configuration to either side of the anterior, middle or occasionally posterior region of the ventral sucker. The long cirrus-sac reaches to a point between a level just posterior to the anterior margin of the ventral sucker and a level just posterior to the ventral sucker. It is usually more or less 


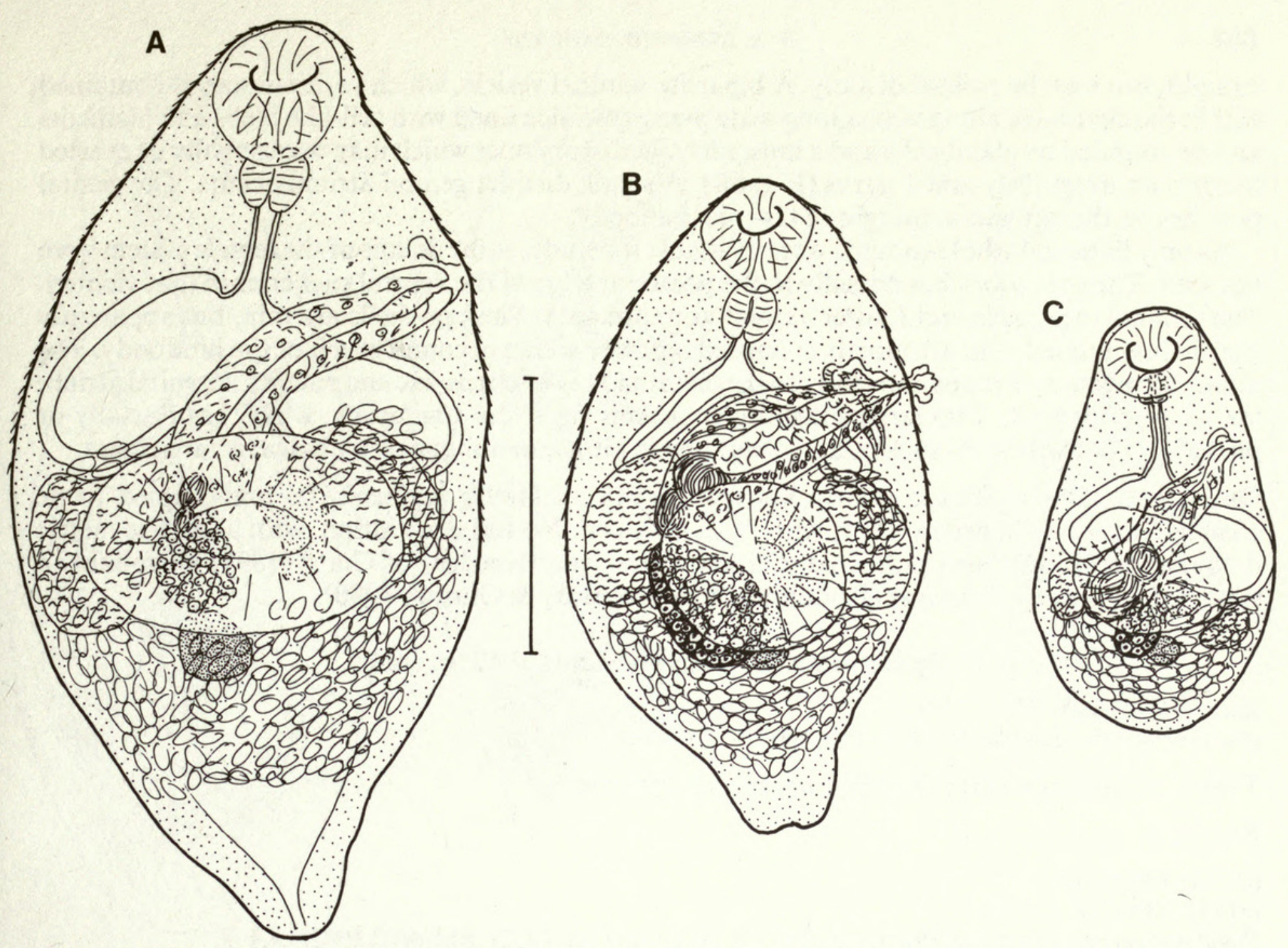

Fig. 6 Diphterostomum betencourti (Monticelli). (A), (B) Flattened specimens, ex Scyliorhinus caniculus; (C) Flattened specimen, ex Scyliorhinus stellaris. Scale bars: A, B, C 0.5 mm.

Table 4 Measurements of Diphterostomum betencourti

\begin{tabular}{|c|c|c|c|}
\hline \multirow{2}{*}{$\begin{array}{l}\text { Authority } \\
\text { Host }\end{array}$} & \multirow{2}{*}{$\begin{array}{l}\text { Odhner (1911a) } \\
\text { S. stellaris }\end{array}$} & \multicolumn{2}{|c|}{ Present study } \\
\hline & & S. caniculus & S. stellaris \\
\hline Length (mm) & $2-2 \cdot 5$ & $0 \cdot 81-1 \cdot 62$ & $0.69-0.75$ \\
\hline Breadth (mm) & $1 \cdot 1-1 \cdot 3$ & $0.41-0.85$ & $0.43-0.44$ \\
\hline $\begin{array}{l}\text { Length : forebody } \\
\text { ratio }\end{array}$ & - & $1: 0.44-0.51$ & $1: 0.43-0.51$ \\
\hline Oral sucker (mm) & 0.3 diam. & $\begin{array}{r}0 \cdot 16-0 \cdot 25 \times \\
0 \cdot 17-0 \cdot 25\end{array}$ & $\begin{array}{r}0 \cdot 15-0 \cdot 17 \times \\
0 \cdot 17-0 \cdot 18\end{array}$ \\
\hline $\begin{array}{l}\text { Ventral sucker } \\
(\mathrm{mm})\end{array}$ & $\begin{array}{l}0.43 \times \\
0.60-0.65\end{array}$ & $\begin{array}{r}0.10-0.32 \times \\
0.27-0.55\end{array}$ & $\begin{array}{r}0 \cdot 19-0.20 \times \\
0 \cdot 29-0.28\end{array}$ \\
\hline Sucker-ratio & - & $1: 1 \cdot 5-2 \cdot 3$ & $1: 1 \cdot 6$ \\
\hline Pharynx (mm) & $0 \cdot 24$ & $\begin{array}{r}0.07-0 \cdot 11 \times \\
0.06-0.12\end{array}$ & 0.08 diam. \\
\hline Oesophagus (mm) & - & $0 \cdot 06-0 \cdot 18$ & $0.06-0.17$ \\
\hline Cirrus-sac (mm) & - & $\begin{array}{r}0.30-0.78 \times \\
0.08-0.18\end{array}$ & $\begin{array}{c}0.40-0 \cdot 41 \times \\
0 \cdot 10\end{array}$ \\
\hline Testes $(\mathrm{mm})$ & - & $\begin{array}{r}0.12-0.30 \times \\
0.07-0.20\end{array}$ & $\begin{array}{r}0 \cdot 17-0 \cdot 18 \times \\
0 \cdot 10-0 \cdot 12\end{array}$ \\
\hline Ovary (mm) & - & $\begin{array}{c}0 \cdot 11-0 \cdot 20 \times \\
0.06-0 \cdot 15\end{array}$ & - \\
\hline Eggs $(\mu \mathrm{m})$ & 34-36 long & $30-34 \times 13-16$ & $31-32 \times 15-16$ \\
\hline
\end{tabular}


straight, but may be twisted distally. A bipartite seminal vesicle, which varies in size, is contained within the cirrus-sac along with a long wide pars prostatica lined with cell-like blebs and filaments and surrounded by gland-cells and a muscular ejaculatory duct which may occasionally be everted to form an irregularly lobed cirrus (Fig. 6B). A small, distinct genital atrium occurs. The genital pore lies on the left lateral margin of the mid-forebody.

As only flattened whole-mounts were available for study, some details of the female system were not seen. The oval ovary lies dorsally to the posterior edge of the ventral sucker or in that vicinity. The seminal receptacle and Laurer's canal were not seen. The egg-shells are thin, but apparently very lightly tanned, and are mostly collapsed, and the uterus occupies much of the hindbody. The muscular metraterm loops anteriorly to the distal end of the cirrus-sac and enters the genital atrium via its anterior wall. Two large subglobular masses form the vitellarium, which lies dorsally or posteriorly to the ventral sucker, the lobes lying in either an oblique or a tandem arrangement.

Discussion. This species is poorly known. Monticelli (1893) replaced the preoccupied name Distoma lutea van Beneden, 1871, with $D$. betencourti. No full description, with adequate metric data, has previously been presented. Cercaria lutea (van Beneden) of Giard (1897) is probably a synonym of Bacciger bacciger (Rudolphi, 1819) (see Bray \& Gibson, 1980).

Diphterostomum vividum (Nicoll, 1912) n. comb.

Zoonogenus vividus Nicoll, 1912.

Zoogonoides vividus (Nicoll, 1912) Yamaguti, 1953.

TYPE-HOST AND LOCALITY. Pagellus bogaraveo, Aberdeen.

\section{RECORDS}

(i) Material studied

(a) From the NE Atlantic

Pagellus bogaraveo [rectum] Plymouth, Devon, England (Oct. 1972). BM(NH) 1982.5.4.1-3.

(b) From elsewhere

None

(ii) NE Atlantic records from the literature

Pagellus bogaraveo [rectum] Aberdeen, Scotland. Nicoll (1912: 200; 1913: 189).

— [rectum] Plymouth, Devon, England. Nicoll (1912: 200; 1913: 189).

ASPECTS OF BIOLOGY. This species is little known. It has only been recorded from the rectum of $P$. bogaraveo in the two localities mentioned above.

PREVIOUS DESCRIPTIONS. Nicoll (1912: 200).

DESCRIPTION (Fig. 7A,B). Five specimens, two as both whole-mounts and serial sections, have been studied. The measurements are included in Table 5. These oval worms have transverse rows of tegumental spines which reach back to about the level of the middle of the ventral sucker. The oral sucker may be terminal and slightly infundibuliform or more or less globular with a subterminal opening. A short prepharynx leads via a small, globular pharynx to a distinct oesphagus which bifurcates in the mid to posterior forebody region. The caeca reach no further posteriorly than the middle of the ventral sucker. In about the middle of the body a large, subcircular ventral sucker is found, without a strongly developed musculature.

The excretory pore is terminal, leading into a small sac-like vesicle, often containing acinous crystalline structures.

The testes, which are not clearly seen in whole-mounted worms, lie symmetrically to slightly obliquely close to the posterior margin of the ventral sucker. They are mainly post-ovarian and lie contiguous with the vitelline masses. The large, recurved cirrus-sac reaches dorsally to the ventral sucker (Fig. 7A,B). The proximal part contains a bipartite seminal vesicle and part of a wide pars prostatica. The distal part runs transversely and contains the remainder of the pars prostatica and a short ejaculatory duct which may be extended to form a cirrus. The small genital atrium opens on the left lateral margin at about the level of the intestinal bifurcation. 

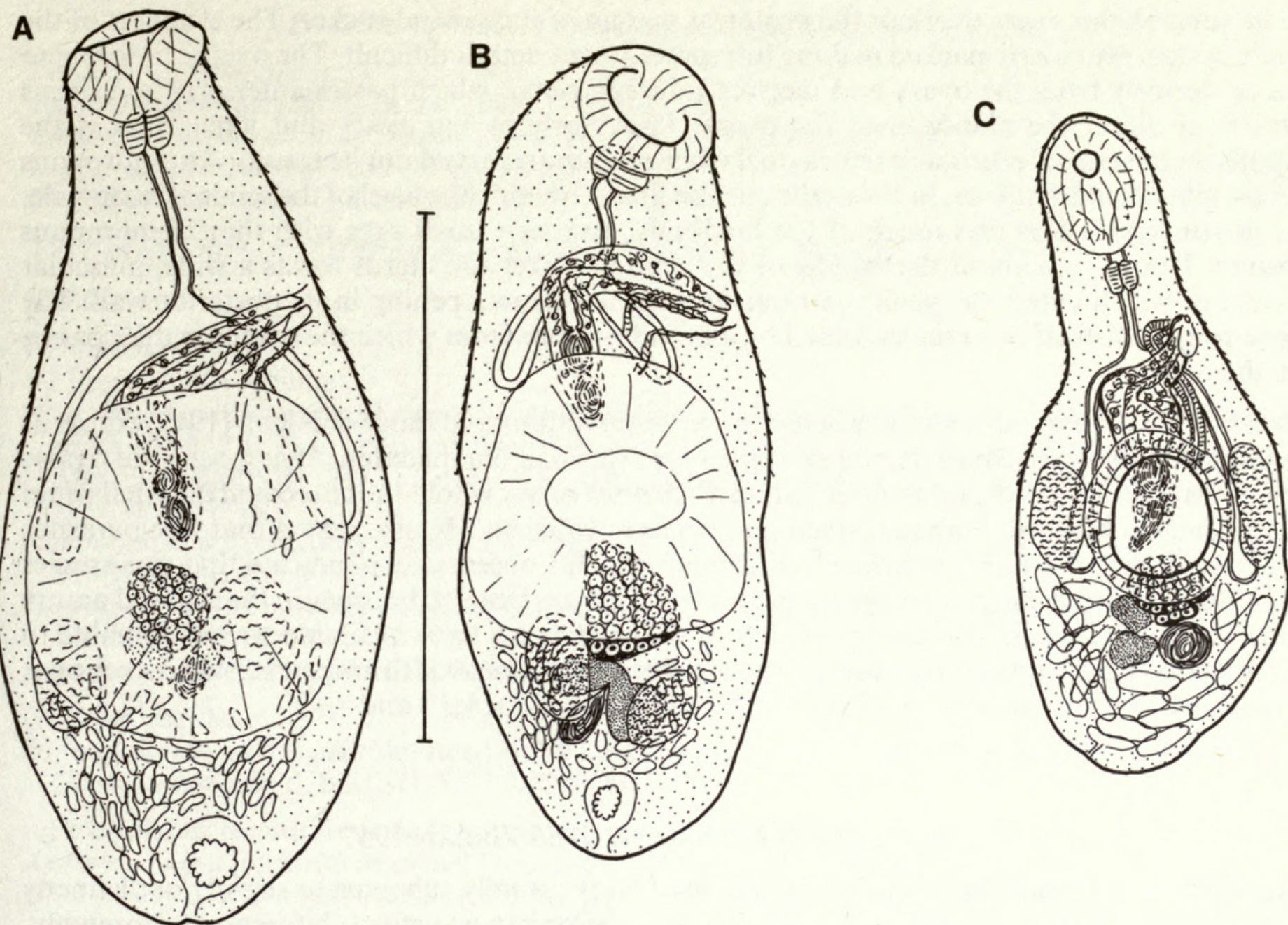

Fig. 7 (A), (B) Diphterostomum vividum (Nicoll), Ventral views; (C) Pseudozoogonoides sp. innom., ex Squalus acanthias, ventral view. Scale bars: A, B, C $0.5 \mathrm{~mm}$.

Table 5 Measurements of Diphterostomum vividum and Pseudozoogonoides sp. innom.

\begin{tabular}{|c|c|c|c|}
\hline \multirow[b]{2}{*}{ Authority } & \multicolumn{2}{|c|}{ Diphterostomum vividum } & \multirow{2}{*}{$\begin{array}{l}\text { Pseudozoogonoides } \\
\text { sp. innom. } \\
\text { Present study }\end{array}$} \\
\hline & Nicoll (1912) & Present study & \\
\hline Length (mm) & av. 1.4 & $0 \cdot 80-0 \cdot 84$ & $0 \cdot 59$ \\
\hline Breadth $(\mathrm{mm})$ & av. 0.46 & $0.32-0.37$ & 0.25 \\
\hline Length : forebody ratio & {$[1: 0 \cdot 50]$} & $1: 0.32-0.37$ & $1: 0 \cdot 49$ \\
\hline Oral sucker $(\mathrm{mm})$ & c. $0 \cdot 16$ diam. & $0.10 \times 0.13$ & $0.11 \times 0.08$ \\
\hline Ventral sucker (mm) & c. 0.34 diam. & $0.30-0.33 \times 0.30$ & $0.15 \times 0.13$ \\
\hline \multicolumn{4}{|l|}{ Sucker-ratio } \\
\hline width & & $1: 2 \cdot 3$ & $1: 1 \cdot 6$ \\
\hline length & & $1: 2 \cdot 08-3 \cdot 3$ & $1: 1 \cdot 4$ \\
\hline Pharynx (mm) & 0.07 diam. & $0.05-0.06$ diam. & $0.32 \times 0.27$ \\
\hline Oesophagus (mm) & $\begin{array}{l}\text { 'shorter than } \\
\text { pharynx' }\end{array}$ & $0.13 \times 0.14$ & 0.07 \\
\hline Cirrus-sac (mm) & - & $0.36-0.41 \times 0.05$ & $0.24 \times 0.06$ \\
\hline Testes (mm) & c. $0.25 \times 0.12$ & - & $0.10-0.11 \times 0.05$ \\
\hline Ovary (mm) & 0.09 & - & $0.075 \times 0.05$ \\
\hline Eggs $(\mu \mathrm{m})$ & $16-36 \times 12-18$ & $31-39 \times 12-19$ & $45-55 \times 14-25$ \\
\hline
\end{tabular}

*Ventral sucker 'distinctly more than twice [size] of oral sucker and in some cases it is nearly three times.' 
The subglobular ovary overlaps the posterior margin of the ventral sucker. The elements of the female system are closely packed making interpretation of details difficult. The oviduct appears to pass posteriorly from the ovary and receives Laurer's canal, which passes anteriorly and opens dorsally at about the mid-level of the ovary. Posteriorly to the ovary and vitellarium is the ampullaceous seminal receptacle with a duct whose full course could not be traced. An amorphous Mehlis' gland apparently lies in about the median line at roughly the level of the seminal receptacle. The uterus, which occupies much of the hindbody, contains small eggs with thin membranous capsules. Dorsally to about the middle of the ventral sucker the uterus forms a wide, muscular metraterm which enters the genital atrium through a narrow opening in its posterior wall. The vitellarium consists of two masses joined by a broad isthmus from which the common duct passes into the oviduct.

Discussion. The major discrepancy between our observations and those of Nicoll (1912) concerns the nature of the vitellarium. Nicoll described it as 'a small compact mass lying near the ovary, sometimes on its right side, sometimes behind it'. In none of our whole-mounts could the vitellarium be adequately observed. Perhaps Nicoll had similar problems. He also stated that 'the parasites were usually in a more or less macerated condition'. Our observations indicate that this species should be included in the genus Diphterostomum and differs from $D$. brusinae in the size and nature of the ventral sucker. In the few specimens of $D$. vividum we have available we were unable to see muscular, lamellar lips on the ventral sucker. Both the sucker-width and sucker-length ratios of $D$. vividum exceed those of $D$. brusinae with no overlap (see Tables 3 and 5).

\section{Genus PSEUDOZOOGONOIDES Zhukov 1957}

DiAGNOSTIC FEATURES. Ventral sucker in middle of body; usually subequal to slightly or distinctly larger than oral sucker. No muscular lamellar lips. Oesophagus distinct, bifurcates in forebody. Caeca narrow, just reach into hindbody. Testes symmetrical at level of ventral sucker. Cirrus-sac variable. Seminal vesicle bipartite. Pars prostatica vesicular. Genital atrium distinct, with atrial sac. Genital pore marginal, sinistral; in mid-forebody. Ovary subglobular, post-testicular. Vitellarium two subequal masses. Uterus fills most of hindbody. Miracidium surrounded by membranous or very weakly tanned egg-capsule. Excretory pore terminal, vesicle small, saccular. (? Metacercaria in teleosts.) Adults in teleosts and elasmobranchs.

Comment. Zhukov (1957) distinguished the genus Pseudozoogonoides from Diphterostomum on the structure of the ventral sucker, which in the latter genus has strongly muscular lamellar lips. To some extent it is a matter of personal preference whether this single character is considered to be of generic importance, but it is suggested (Bray, in press $a$ ) that Pseudozoogonoides should be retained for those zoogonines with two vitelline masses, relatively narrow elongate caeca and an atrial sac. Skrjabin (1957) referred to Zhukov's unpublished dissertation and mentioned two possible further differentiating features. These are: (1) that Diphterostomum is a southern form while Pseudozoogonoides is northern, and (2) the known details of the life-cycle are different, in that the metacercariae of $P$. microacetabulum (=subaequiporus) are said to occur in a fish.

The genus Pseudozoogonoides has been credited with two further species, P. ugui Shimazu, 1974, from the posterior intestine of the cyprinid Tribolodon hakonesis from inshore waters and a river in Japan, and P. albulae (Overstreet, 1969) Madhavi, 1979 from the intestine and pyloric caeca of Albula vulpes from Florida. P. albulae was originally placed in Diphterostomum and is considered a member of that genus.

\section{Key to Pseudozoogonoides spp. found in the north-east Atlantic}


Pseudozoogonoides subaequiporus (Odhner, 1911) n. comb.

Zoogonoides subaequiporus Odhner, 1911.

Diphterostomum microacetabulum Shulman-Albova, 1952.

Pseudozoogonoides microacetabulum (Shulman-Albova, 1952) Zhukov, 1957.

Zoogonoides viviparus of Scott $(1973,1975 a, b)$.

(?) Diphterostomum sp. of Brinkmann (1975).

TYPE-HOST AND LOCALITY. Anarhichas lupus, Trondheim, Norway.

\section{RECORDS}

(i) Material studied

(a) From the NE Atlantic

Anarhichas lupus [intestine, posterior intestine] off NE Scotland $\left(58^{\circ} \mathrm{N}, 00^{\circ}\right.$; depth $99-111 \mathrm{~m}$; and $59^{\circ} \mathrm{N}, 01^{\circ} \mathrm{E}$; depth 107-117 m; Dec. 1979) BM(NH) 1982.4.21.13-16; Bell Rock, North Sea $\left(56^{\circ} \mathrm{N}, 02^{\circ} \mathrm{W}\right.$; depth $52 \mathrm{~m}$; May 1982) BM(NH) 1983.11.23.17-18; W of Bressay Bank $\left(59^{\circ} \mathrm{N}, 00^{\circ}\right.$; depth $140 \mathrm{~m}$; June 1983) BM(NH) 1983.11.23.17-18.

Anarhichas minor [intestine] Anton Dohrn Bank, E, Greenland $\left(66^{\circ} \mathrm{N}, 30^{\circ} \mathrm{W}\right.$; depth $336-380 \mathrm{~m}$; May 1973) $\mathrm{BM}(\mathrm{NH})$ 1982.4.21.17-19.

Hippoglossoides platessoides [intestine] Latragrunn, W. Iceland $\left(66^{\circ} \mathrm{N}, 27^{\circ} \mathrm{W}\right.$; depth $216-228 \mathrm{~m}$; May 1973$)$ $\mathrm{BM}(\mathrm{NH})$ 1982.4.21.20.

Lycodes esmarkii [intestine] Foula, Scotland $\left(60^{\circ} \mathrm{N}, 06^{\circ} \mathrm{W}\right.$; depth $800 \mathrm{~m}$; June 1974) BM(NH) 1982.4.21.21.

(b) From elsewhere

Hippoglossoides platessoides [intestine] off Newfoundland and Nova Scotia, Canada (see Bray, 1979: 417; as D. microacetabulum). BM(NH) 1977.2.15.54-58

(ii) NE Atlantic records from the literature

Anarhichas lupus [posterior intestine] Trondheim, Norway (1905). Odhner (1911a: 244).

(?) Anarhichas minor [gall-bladder] Off Umîvik, E. Greenland (July, 1959). Brinkmann (1975: 40; as Diphterostomum sp.).

ASPECTS OF BIOLOGY. The life-history of this worm is not known in any detail. The miracidium, which bears a dense coat of cilia, is enclosed by a thin membranous capsule, but according to Shulman-Albova (1952) hatches and swims freely in the host's intestine. There appears to be a direct relationship between 'viviparity' and the situation in the posterior part of the gut. The host of the sporocyst generations is not known. Cercaria zoogonoides Chubrik, 1966 from the gastropods Buccinum finmarchianum and Sipho islandicus from the Barents Sea could represent this species or possibly Zoogonoides viviparus. Shulman-Albova (1952), drawing a parallel with Diphterostomum brusinae, speculated that gastropods of the genus Natica constitute the first intermediate hosts and that the definitive host (Anarhichas in this case) gains the parasite directly by feeding on these molluscs. The parallel with $D$. brusinae, however, may not be valid as we do not consider Diphterostomum and Pseudozoogonoides to be particularly closely related.

The only record of metacercariae is that of Zhukov (1960), who claimed to have found some in the mesenteries of the flatfish Limanda punctatissima punctatissima in the north Pacific Ocean. Scott's (1975a) studies suggested to him that brittle-stars were the second intermediate hosts of his 'Zoogonoides viviparus' which he later (1982) re-identified as Diphterostomum microacetabulum [ $=$ P. subaequiporus $]$.

The adult worm has been recorded in the north-east and north-west Atlantic, the White and Barents Seas and in various regions of the north Pacific. Most records are from pleuronectid flatfishes and anarhichadids, but cottids, zoarcids and salmonids are also recorded as hosts. In the north-west Atlantic, however, it apparently occurs only in Hippoglossoides platessoides and has been known under the name 'Zoogonoides viviparus' in that region. As mentioned above, Scott (1982) corrected his earlier identifications $(1973,1975 a, b)$ of worms from $H$. platessoides, and all the zoogonine worms we have recovered from this host in the north-west Atlantic (Bray, 1979) are $P$. subaequiporus.

PREVIOUS DESCRIPTIONS. Odhner (1911a: 244); Shulman-Albova (1952: 86; as Diphterostomum microacetabulum); Shulman \& Shulman-Albova (1953: 46; as D. microacetabulum); Zhukov (1960: 

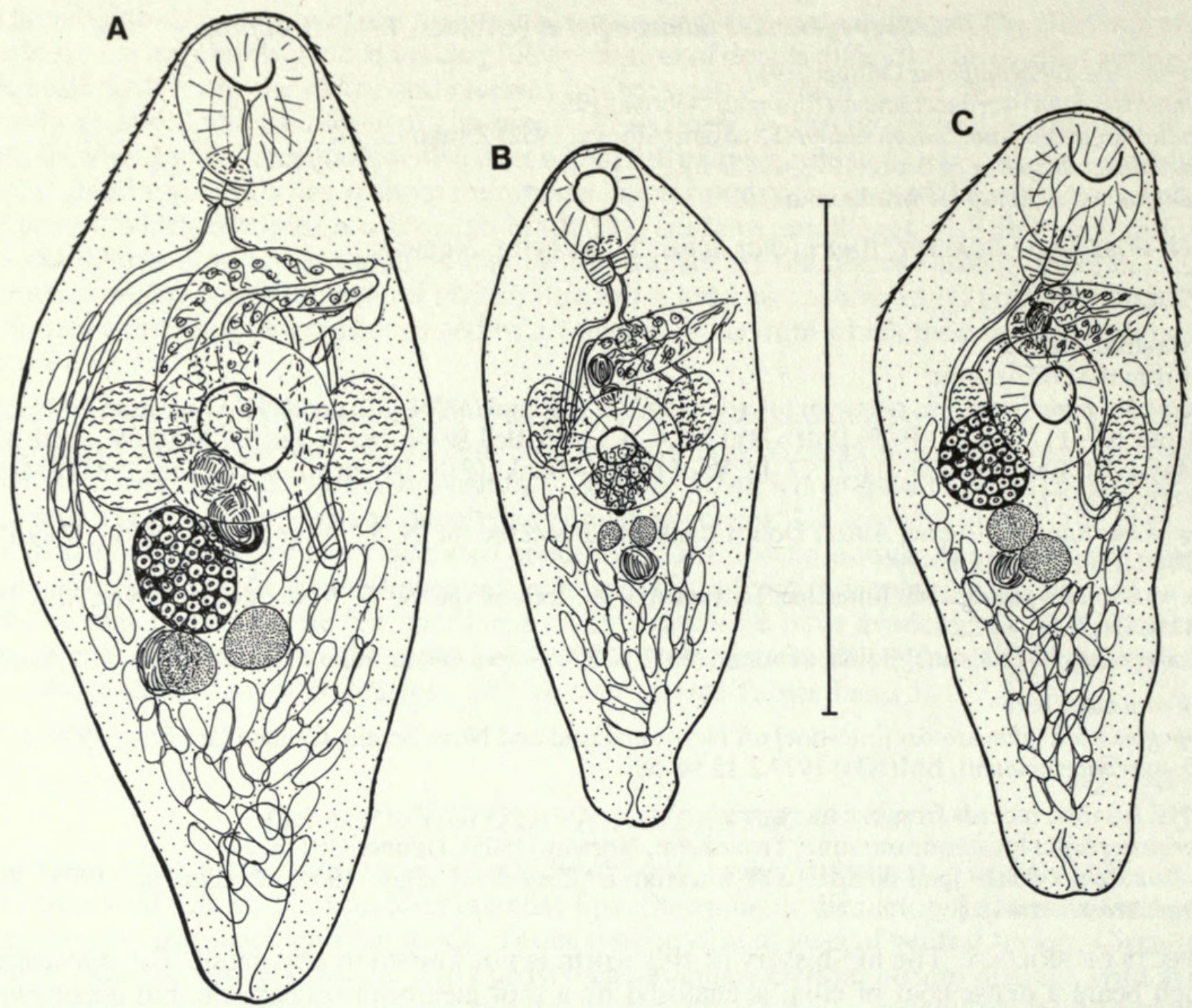

Fig. 8 Pseudozoogonoides subaequiporus (Odhner). (A) Ventral view, ex Anarhichas lupus, Scotland;

(B) Ventral view, ex Hippoglossoides platessoides, Canada; (C) Ventral view, ex Lycodes esmarkii, Scotland. Scale bars: A, B, C 0.5 mm.

28; as Pseudozoogonoides microacetabulum); Brinkmann (1975: 38; as D. microacetabulum and (?) Diphterostomum sp.).

DESCRIPTION (Fig. 8). Forty-six whole-mounts and five sets of serial sections were examined. For measurements see Table 6 . These small fusiform worms are normally widest in the forebody and may bear transverse rows of small, peg-like spines. The spines are more often than not apparently worn down, or at least not clearly seen. The subterminal oral sucker leads, via a short prepharynx, into a small, globular pharynx. The oesophagus divides in the mid-forebody region, giving rise to narrow caeca which terminate at about the level of the posterior margin of the ventral sucker or posterior margin of the testes, but this varies a little either anteriorly or posteriorly to that point. The subcircular ventral sucker is nearly always slightly larger than the oral.

The terminal excretory pore leads into an elongate, oval excretory vesicle which reaches almost half-way along the hindbody.

Oval testes lie almost symmetrically at the level of the ventral sucker, but occasionally one of the pair may be displaced into the forebody. The cirrus-sac is a variable structure and may be claviform and straight or distinctly recurved, i.e. formed of two parts: the distal part running almost transversely across the body and the proximal part running longitudinally. Intermediate forms occur (Fig. 8B) and, therefore, these differences cannot be considered as of taxonomic importance (see also D. brusinae, p. 139). The figures in Zhukov (1960) and Brinkmann (1975) show that this variation also occurs in other parts of the species' range. A seminal vesicle consisting of two oval parts lies proximally within the cirrus-sac. It leads into a wide, oval, vesicular pars prostatica, lined 
Table 6 Measurements of Pseudozoogonoides subaequiporus

\begin{tabular}{|c|c|c|c|c|}
\hline Host & $\begin{array}{l}\text { Anarhichas } \\
\text { lupus }\end{array}$ & $\begin{array}{l}\text { Anarhichas } \\
\text { minor }\end{array}$ & $\begin{array}{l}\text { Hippoglossoides } \\
\text { platessoides }\end{array}$ & $\begin{array}{l}\text { Lycodes } \\
\text { esmarkii }\end{array}$ \\
\hline Length (mm) & $0.81-0.96$ & $0.65-0.69$ & $0.67-1.04$ & 0.76 \\
\hline Breadth (mm) & $0.31-0.40$ & $0 \cdot 20$ & $0.24-0.38$ & 0.30 \\
\hline $\begin{array}{l}\text { Length : forebody } \\
\text { ratio }\end{array}$ & $1: 0 \cdot 27-0 \cdot 35$ & $1: 0 \cdot 34-0 \cdot 38$ & $1: 0 \cdot 30-0 \cdot 36$ & $1: 0 \cdot 28$ \\
\hline Oral sucker (mm) & $\begin{array}{r}0 \cdot 15-0 \cdot 16 \times \\
0 \cdot 15-0 \cdot 17\end{array}$ & $\begin{array}{c}0 \cdot 12-0 \cdot 13 \times \\
0 \cdot 11\end{array}$ & $\begin{array}{r}0.09-0 \cdot 18 \times \\
0.09-0.12\end{array}$ & $0.13 \times 0.12$ \\
\hline $\begin{array}{l}\text { Ventral sucker } \\
(\mathrm{mm})\end{array}$ & $\begin{array}{r}0 \cdot 17-0 \cdot 18 \times \\
0 \cdot 15-0 \cdot 18\end{array}$ & $0.12 \times 0.11$ & $\begin{array}{c}0 \cdot 10-0 \cdot 16 \times \\
0 \cdot 10-0 \cdot 14\end{array}$ & $0.14 \times 0.12$ \\
\hline Sucker-ratio & $1: 1 \cdot 0-1 \cdot 2$ & $1: 0.98$ & $1: 1 \cdot 0-1 \cdot 3$ & $1: 1 \cdot 0$ \\
\hline Pharynx (mm) & $0.05-0.055$ diam. & 0.034 diam. & $\begin{array}{r}0.040-0.055 \times \\
0.045-0.055\end{array}$ & $0.05 \times 0.055$ \\
\hline Oesophagus (mm) & 0.05 & present? & $0.02-0.075$ & $?$ \\
\hline Cirrus-sac (mm) & $\begin{array}{l}\text { straight } \\
0.35 \\
\text { recurved* } \\
\text { (A) } 0.22-0.23 \\
\text { (B) } 0.22-0.25 \times \\
0.035-0.08\end{array}$ & $0.22 \times 0.05$ & $\begin{array}{l}\text { straight } \\
0 \cdot 18-0.34 \\
\text { recurved* } \\
\text { (A) } 0 \cdot 14-0 \cdot 28 \\
\text { (B) } 0 \cdot 07-0 \cdot 19 \times \\
0.05-0.08\end{array}$ & $0.15 \times 0.05$ \\
\hline Testes (mm) & $\begin{array}{c}0 \cdot 11-0 \cdot 15 \times \\
0 \cdot 09-0 \cdot 11\end{array}$ & $\begin{array}{c}0.08-0.09 \times \\
0.05\end{array}$ & $\begin{array}{r}0.08-0.11 \times \\
0.04-0.09\end{array}$ & $\begin{array}{r}0.06-0.09 \times \\
0.05-0.06\end{array}$ \\
\hline Ovary (mm) & $\begin{array}{l}0.13 \times \\
0.10-0.11\end{array}$ & $0.07 \times 0.06$ & $\begin{array}{r}0.06-0 \cdot 10 \times \\
0.05-0.10\end{array}$ & $0.08 \times 0.10$ \\
\hline Miracidium $(\mu \mathrm{m})$ & $67-80 \times 27-32$ & $55-62 \times 20$ & $62-70 \times 25$ & $53-57 \times 22-23$ \\
\hline
\end{tabular}

${ }^{*}$ Recurved cirrus-sac length measured in two parts: (A) distal part, (B) proximal part.

with cell-like, but apparently anuclear, structures and surrounded by glandular cells and connective tissue. Distally the pars prostatica narrows to form the ejaculatory duct, which opens into the base of the genital atrium. A small sac-like diverticle arises from the posterior margin of the genital atrium. The genital pore opens on the left margin of the mid-forebody or just ventrally sublateral.

The oval ovary lies on about the median line, overlapping the posterior border of the ventral sucker. From the ovary the oviduct passes posteriorly and receives the ducts from the seminal receptacle and Laurer's canal, close together, and the common vitelline duct. The seminal receptacle is variable in size, but is often a large, globular structure. A narrow Laurer's canal arises close to the opening of the seminal receptacle into the oviduct, so close in fact that it may be interpreted as a common opening, and passes dorsally to open on the surface dorsally to the seminal receptacle. Mehlis' gland is inconspicuous, lying, as far as can be ascertained, just anterior to the vitellarium. The uterus occupies much of the hindbody and contains numerous fairly large eggs with very thin capsules with little or no sign of tanning. The metraterm is wide and muscular, surrounded by gland-cells and opens into the base of the genital atrium. The vitellarium consists of two compact masses which are connected by a broad isthmus which feeds the oviduct through a common duct.

Discussion. This species is best known under the names Diphterostomum and Pseudozoogonoides microacetabulum, but, as such, has never been recorded in the north-east Atlantic. We have found it on a number of occasions, including two where it was sympatric with Zoogonus rubellus. Odhner (1911a) described briefly a form which he considered close to Zoogonoides viviparus, which he named Zoogonoides subaequiporus as the ventral sucker was much smaller. This characteristic fits closely with the present species, and, in fact, is the most convenient feature for initial differentiation 
from Z. viviparus. The host Odhner mentions is Anarhichas lupus, which is also the type-host of Diphterostomum microacetabulum, originally reported from the White Sea. We have found specimens indistinguishable from $D$. microacetabulum from the same host in regions off northeast Scotland, and, therefore, it is likely that the distribution stretches from north Britain up the Norwegian coast to the Barents Sea (Polyansky, 1955) and the White Sea (Shulman-Albova, 1952; Shulman \& Shulman-Albova, 1953). This part of this species' range includes Trondheim, the typelocality of $Z$. subaequiporus. Shulman-Albova (1952) considered it likely that $Z$. subaequiporus and D. microacetabulum were synonyms and the evidence presented by the discovery of this parasite fairly commonly in the north-east Atlantic region makes this likelihood so strong that we have taken the step of sinking $D$. microacetabulum into what is now P. subaequiporus.

The unnamed Diphterostomum sp. of Brinkmann (1975) from the gall-bladder of Anarhichas minor off east Greenland is very similar to D. subaequiporus and is, herein, tentatively considered a young representative of this species. The distinguishing features mentioned by Brinkmann should, however, be born in mind. He enumerates six, these are: (1) parasite of gall-bladder; (2) easily observed tegumental spines; (3) more posteriorly situated ventral sucker; (4) the wide, thin-walled intestinal caeca; (5) testes side by side level with, or posterior to ovary; and (6) large excretory vesicle. Some of these characters $(2,3,5)$ may result from immaturity, while others $(? 4,6)$ may result from the different physiological regime encountered in the gall-bladder.

Pseudozoogonoides ugui differs from $P$. subaequiporus in having a relatively larger ventral sucker (sucker ratio $1: 1 \cdot 28-1 \cdot 78$ ) and larger eggs. The latter character is not a clear-cut one, as our measurements show that the egg-sizes reach into the range given by Shimazu (1974), and the egg-size in this subfamily tends to be somewhat unreliable. Two other distinguishing features mentioned by Shimazu are not valid, since the diverticulum of the genital atrium (atrial sac) is present in both species and the position of the genital pore is more or less identical.

\section{Pseudozoogonoides sp. innom.}

\section{RECORDS}

(i) Material studied

Squalus acanthias [spiral valve] Faxa Floi, S.W. Iceland (Oct. 1966) Collector: B. R. Manger. BM(NH) 1982.5.4.4.

ASPECTS OF BIOLOGY. Manger (1972) collected helminths from seven specimens of S. acanthias and 'some small, unidentified digenetic trematodes were found in the stomach and spiral valve'. Those from the stomach are Derogenes varicus (Müller, 1780), while the single specimen from the spiral valve is described below as $P$. sp. innom. The Derogenes are certainly accidental records in elasmobranchs (Threlfall, 1969; McVicar, 1977; Orlowska, 1980), but it is not possible to be certain if this is the case for $P$. sp. innom. Its location in the spiral valve and the known occurrence of the related worms in elasmobranchs (i.e. D. betencourti) indicate that $S$. acanthias may be a preferred host.

\section{PREVIOUS DESCRIPTIONS.}

None

DESCRIPTION (Fig. 7C). The single worm available is of a pyriform shape, widest in the region of the ventral sucker (Fig. 7C). The dimensions are given on Table 5 . The spines on the body surface reach back as far as the ventral sucker with a patch on the ventral surface posterior to the ventral sucker. An oval oral sucker opens subterminally, leading via a distinct prepharynx into a small, oval pharynx. The long oesophagus reaches into the posterior forebody before bifurcating to form two narrow caeca which reach to about the posterior margin of the testes and the ventral sucker. The ventral sucker has a wide opening and a fairly narrow muscular wall, but it is distinctly larger than the oral sucker and lies just within the posterior half of the body.

The excretory pore is terminal and the vesicle, although not clearly seen, may be a small, flattened sac posterior to the uterine field.

The two oval testes lie, with their long axes longitudinal, on either side of the ventral sucker. The cirrus-sac is long and recurved, reaching almost to the ovary. It contains a bipartite seminal vesicle, 
the distal part being globular and the proximal elongate-saccular. The pars prostatica forms a wide, oval vesicle and narrows distally where it is lined with filamentous structures. The cirrus-sac also contains numerous gland-cells. The ejaculatory duct opens into a distinct genital atrium with a small diverticulum (atrial sac). The genital pore lies on the ventral surface very close to the left margin of the body, in about the middle of the forebody.

The irregularly lobed ovary lies overlapping the posterior margin of the ventral sucker. A small, globular seminal receptacle lies to the left of the vitelline masses, immediately posterior to the ovary. The uterus occupies most of the posterior part of the worm and contains numerous large eggs, with thin, but apparently rigid, capsules. The metraterm is strongly muscular and runs from the hindbody towards the cirrus-sac over which it loops dorsally to enter the genital atrium from the anterior aspect. Two small, irregular vitelline masses lie in tandem postero-dextral to the ovary.

Discussion. This single worm appears to differ from other described species of the genus, although from a single specimen no indication of intra-specific variation is possible. It differs from $P$. subaequiporus primarily in the sucker ratio, from the other species, $P$. ugui by egg-size, caeca and cirrus-sac length and from both species by its occurrence in an elasmobranch.

\section{Genus ZOOGONOIDES Odhner, 1902}

Diagnostic fEATURES. Prepharynx short. Oesophagus bifurcates in posterior forebody. Caeca narrow, reach close to testes or beyond. Cirrus-sac claviform with bipartite seminal vesicle. Distinct genital atrium with atrial sac usually present. Genital pore at or near lateral margin in mid-forebody. Ovary oval, post-testicular. Vitellarium single globular mass. Egg-capsules membranous. Sporocysts in gastropods. Tail-less xiphidiocercaria. Metacercaria in polychaetes, echinoderms, gastropods and bivalves. Adults in marine teleosts.

COMment. Only one species occurs in the north-east Atlantic.

\section{Zoogonoides viviparus (Olsson, 1868) Odhner, 1902}

Distoma viviparum Olsson, 1868.

Zoogonus viviparus (Olsson, 1868) Looss, 1901.

(?) Distoma callionymi van Beneden, 1871.

(?) Cercaria megalocotylea Villot, 1878.

Cercaria capriciosa Cuénot, 1892.

Cercaria giardi Pelseneer, 1906.

(?) Cercaria limae Nicoll \& Small, 1909.

(?) Metacercaria limae (Nicoll \& Small, 1909) James, Sannia \& Bowers, 1977.

TYPE-HOST AND LOCALITY. Microstomus kitt, Bergen, Norway.

\section{RECORDS}

(i) Material studied

(a) From the NE Atlantic

Callionymus lyra [rectum, posterior intestine] Plymouth, Devon, England. Collector: M. Rothschild. $\mathrm{BM}(\mathrm{NH})$ 1932.11.22.43; and (May, 1972). BM(NH) 1982.3.4.13-20.

- [intestine] off Myggenoes, Faeroe Bank $\left(61^{\circ} \mathrm{N}, 09^{\circ} \mathrm{W}\right.$; depth $172-176 \mathrm{~m}$; July, 1976). BM(NH) 1982.3.4.21.

- [intestine] NNW Flannan Is., NW Scotland $\left(58^{\circ} \mathrm{N}, 08^{\circ} \mathrm{W}\right.$; depth $116-120 \mathrm{~m}$; July, 1976). BM(NH) 1982.3.4.22.

— [intestine] W of Hoy Sound, Orkneys $\left(60^{\circ} \mathrm{N}, 04^{\circ} \mathrm{W}\right.$; depth $96-97 \mathrm{~m}$; July, 1976). BM(NH) 1982.3.4.23.

— [intestine] off Wick, Moray Firth, Scotland $\left(58^{\circ} \mathrm{N}, 03^{\circ} \mathrm{W}\right.$; depth $62-65 \mathrm{~m}$; July, 1976). BM(NH) 1982.3.4.24-25.

- [rectum, posterior intestine] northern North Sea $\left(59^{\circ} \mathrm{N}, 04^{\circ} \mathrm{W}\right.$; depth $66 \mathrm{~m}$; and $58^{\circ} \mathrm{N}, 03^{\circ} \mathrm{W}$; depth $35 \mathrm{~m}$; June, 1982). BM(NH) 1982.9.14.1-50.

Callionymus maculatus [posterior intestine, rectum] NE off Scotland $\left(58^{\circ} \mathrm{N}, 02^{\circ} \mathrm{W}\right.$; depth $79-81 \mathrm{~m}$; Dec., 1979). BM(NH) 1982.3.4.26.

Callionymus reticulatus [rectum, posterior intestine] Firth of Forth $\left(56^{\circ} \mathrm{N}, 02^{\circ} \mathrm{W}\right.$; depth $60 \mathrm{~m}$; May, 1982).

$\mathrm{BM}(\mathrm{NH})$ 1982.9.14.51-55. 
Glyptocephalus cynoglossus [intestine] NW Flannan Is., NW Scotland $\left(59^{\circ} \mathrm{N}, 06^{\circ} \mathrm{W}\right.$; depth $106-108 \mathrm{~m}$; July, 1976). BM(NH) 1982.3.4.27.

Gobius niger [posterior intestine, rectum] Crouch estuary, Essex, England. (May, 1980). BM(NH) 1982.3.4.28-29

Hippoglossoides platessoides [intestine, rectum] Aberdeen, Scotland. (Oct., 1973; March, 1977). BM(NH) 1982.3.4.30-33.

[intestine] Latragrunn, W of Iceland $\left(66^{\circ} \mathrm{N}, 26^{\circ} \mathrm{W}\right.$; depth $248-250 \mathrm{~m}$; May, 1973). BM(NH) 1982.3.4.34.;

$\left(65^{\circ} \mathrm{N}, 26^{\circ} \mathrm{W}\right.$; depth $110-208 \mathrm{~m}$; May, 1974). BM(NH) 1982.3.4.35.

- [rectum] Øresund, Helsingør, Denmark (Aug., 1981). BM(NH) 1982.3.4.36

- [intestine, rectum] Firth of Forth $\left(56^{\circ} \mathrm{N}, 02^{\circ} \mathrm{W}\right.$; depth $60 \mathrm{~m}$; May, 1982). BM(NH) 1982.9.14.56-60.

[rectum] Alle Bank, North Sea $\left(60^{\circ} \mathrm{N}, 03^{\circ} \mathrm{E}\right.$; depth $120 \mathrm{~m}$; May, 1983). BM(NH) 1983.6.22.20.

Hippoglossus hippoglossus [rectum] SE Sule (59 $\mathrm{N}, 04^{\circ} \mathrm{W}$; depth $55 \mathrm{~m}$; June, 1982). BM(NH) 1982.9.14.61-62.

Lepidorhombus whiffiagonis [?] Off Aberdeen, Scotland. BM(NH) 1982.3.4.37-38.

Limanda limanda [intestine] 'Off Scottish coast'. Collector: Z. Kabata. BM(NH) 1964.6.23.4/25-28.

— [posterior intestine] Plymouth, Devon, England. (May, 1972). BM(NH) 1982.3.4.39.

- [rectum, intestine] Aberdeen, Scotland. (Oct., 1973) BM(NH) 1982.3.4.40-41.

[intestine] off Wick, Moray Firth, Scotland. (58 N, 02 ${ }^{\circ} \mathrm{W}$; depth 96-106 m; July, 1976). BM(NH)

1982.3.4.42.

- [rectum, intestine] Kristineberg, Sweden. (Aug., 1976). BM(NH) 1982.3.4.43.

- [rectum] Crouch estuary, Essex, England. BM(NH) 1982.3.4.44.

- [intestine] Tromsø, Norway (June, 1980) BM(NH) 1982.3.4.45.

- [rectum] Øresund, Helsingør, Denmark (Aug., (1981). BM(NH) 1982.3.4.46-48.

[posterior intestine, rectum] Montrose Bank, North Sea $\left(56^{\circ} \mathrm{N}, 02^{\circ} \mathrm{W} ; \operatorname{depth} 50 \mathrm{~m}\right.$; May, 1982). BM(NH) 1982.9.14.63-80.

[rectum] Turbot Bank, North Sea $\left(57^{\circ} \mathrm{N}, 01^{\circ} \mathrm{W}\right.$; depth $67 \mathrm{~m}$; June, 1982). BM(NH) 1982.9.14.63-80.

[posterior intestine, rectum] Moray Firth $\left(58^{\circ} \mathrm{N}, 03^{\circ} \mathrm{W}\right.$; depths 64 and $35 \mathrm{~m}$; June, 1982). BM(NH) 1982.9.14.63-80.

Microchirus variegatus [intestine] off SW Ireland. $\left(48^{\circ} \mathrm{N}, 09^{\circ} \mathrm{W}\right.$; depth $145-174 \mathrm{~m}$; Jan., 1971). BM(NH)

1982.3.4.49.

[intestine] Bay of Biscay ( $44^{\circ} \mathrm{N}, 07^{\circ} \mathrm{W}$; depth $272-280 \mathrm{~m}$; Jan., 1971). BM(NH) 1982.3.4.50.

[intestine] NW of Flannan Is., NW Scotland. (59 N, 06 ${ }^{\circ}$ W; depth 106-108 m; July, 1976). BM(NH)

1982.3.4.51.

Microstomus kitt [rectum] Plymouth, Devon, England. (May, 1982). BM(NH) 1982.3.4.52.

— [intestine] Aberdeen, Scotland. (Oct., 1973). BM(NH) 1982.3.4.53.

- [rectum] Lossiemouth, Grampian, Scotland. (Oct., 1973). BM(NH) 1982.3.4.54.

- [intestine] Faeroe Islands. $\left(62^{\circ} \mathrm{N}, 08^{\circ} \mathrm{W}\right.$; depth $112 \mathrm{~m}$; July, 1976). BM(NH) 1982.3.4.55.

— [intestine] Moray Firth. $\left(58^{\circ} \mathrm{N}, 02^{\circ} \mathrm{W}\right.$; depth $156 \mathrm{~m}$; July, 1976). BM(NH) 1982.3.4.56.

— [intestine] Øresund, Helsingør, Denmark. (Aug., 1981). BM(NH) 1982.3.4.88-89.

- [posterior intestine, rectum] Moray Firth. ( $58^{\circ} \mathrm{N}, 03^{\circ} \mathrm{W}$; depth $64 \mathrm{~m}$; June, 1982). BM (NH) 1982.9.14.81.

Platichthys flesus [rectum] sea off Aberdeen. (Material of Gibson, 1972). BM(NH) 1972.3.27.15.; (Oct., 1973).

BM(NH) 1982.3.4.57.

- [rectum] Plymouth, Devon, England. (April, 1969). BM(NH) 1982.3.4.58.; (May, 1972). BM(NH)

1982.3.4.59-60.

Pleuronectes platessa [rectum] Plymouth, Devon, England. (May, 1932). Collector: H. A. Baylis. BM(NH)

1932.11.28.1-8; (May, 1972). BM(NH) 1982.3.4.61-63.

- [intestine] off Scottish coast. Collector: Z. Kabata. BM(NH) 1964.6.23.5-24.

_ [intestine] Southern North Sea. Collector: J. F. Wickins. BM(NH) 1966.1.13.39-41.

[intestine] Faeroe Islands. $\left(62^{\circ} \mathrm{N}, 08^{\circ} \mathrm{W}\right.$; depth $112-120 \mathrm{~m}$; July, 1976). BM(NH) 1982.3.4.64.

- [rectum] Kristineberg, Sweden. (Aug., 1977). BM(NH) 1982.3.4.65-66.

- [intestine, rectum] Aberdeen, Scotland. (March, 1977). BM(NH) 1982.3.4.67.

[posterior intestine, rectum] Crouch estuary, Essex, England. (Sept., 1979). BM(NH) 1982.3.4.68-70.

- [rectum] off Start Point, Devon, England. (March, 1980). BM(NH) 1982.3.4.71.

- [rectum] Øresund, Helsingør, Denmark. (Aug., 1981). BM(NH) 1982.3.4.72-74.

[rectum] Swatchway, North Sea $\left(58^{\circ} \mathrm{N}, 01^{\circ} \mathrm{E}\right.$; depth $84 \mathrm{~m}$; June, 1982) BM(NH) 1982.2.9.82-85.

Pomatoschistus minutus [intestine, rectum] Crouch estuary, Essex, England. (Sept., Oct., 1979). BM(NH) 1982.3.4.75-77.

Solea vulgaris [rectum, intestine] Plymouth, Devon, England. (May, Oct., 1972). BM(NH) 1982.3.4.78-82.

- [posterior intestine, rectum] Crouch estuary, Essex, England. BM(NH) 1982.3.4.83-85. 
Zeus faber [intestine] Bay of Biscay. $\left(45^{\circ} \mathrm{N}, 03^{\circ} \mathrm{W}\right.$; depth $132-280 \mathrm{~m}$; Jan., 1971). BM(NH) 1982.3.4.86.

— [rectum] Plymouth, Devon, England. (May, 1972) BM(NH) 1982.3.4.87.

(b) From elsewhere

None.

(ii) NE Atlantic records from the literature

Anarhichas lupus [rectum, intestine] St Andrews Bay, Scotland. Nicoll (1909: 16; 1914: 483).

Blennius gattorugine [rectum, intestine] Plymouth, Devon, England. Nicoll (1914: 483).

Blennius ocellaris [rectum] Plymouth, Devon, England. Nicoll (1914: 483).

Callionymus lyra [posterior intestine] Kristineberg, Sweden. Odhner (1902: 62).

— [intestine] St Andrews Bay, Scotland. Nicoll (1909: 16),

- [rectum] Millport, Firth of Clyde, Scotland. Nicoll (1910: 348).

_ [rectum] Plymouth, Devon, England. Nicoll (1914: 483); Baylis \& Jones (1933: 630); Baylis (1939: 483).

(?) - [intestine] Belgian coast, van Beneden (1871: 53; as Distoma callionymi - unrecognizable).

Glyptocephalus cynoglossus [rectum] North Sea. Nicoll (1909: 16).

- [rectum] Aberdeen, Scotland. Nicoll (1913: 190).

Gobius niger [posterior intestine, rectum] Bergen, Norway. Køie (1976: 12).

Hippoglossoides platessoides [posterior intestine] Kristineberg, Sweden. Odhner (1902: 62).

- [posterior intestine] Northumberland coast, England. Lebour (1908: 53).

- [?] North Sea. Nicoll (1909: 16).

[rectum] Aberdeen, Scotland. Nicoll (1913: 190).

— [posterior intestine] Øresund, Denmark. Køie (1976: 1).

Limanda limanda [posterior intestine] Kristineberg, Sweden. Odhner (1902: 62).

- [rectum] St Andrews Bay, Scotland. Nicoll (1907: 83).

— [posterior intestine] Northumberland coast, England. Lebour (1908: 53).

- [rectum] Millport, Firth of Clyde, Scotland. Nicoll (1910: 348).

_- [rectum] Plymouth, Devon, England. Nicoll (1914: 483).

- [rectum] Aberdeen, Scotland. Nicoll (1915: 360).

- [rectum] Galway Bay, Ireland. Little (1929: 26).

— [posterior intestine, rectum] Danish waters. Køie (1976: 1; 1981: 61; 1983: 215).

- [posterior intestine, rectum] Faeroe Islands. Køie (1983: 215).

Microchirus variegatus [rectum, intestine] Plymouth, Devon, England. Nicoll (1914: 483).

Microstomus kitt [stomach] Bergen, Norway. Olsson (1868: 28).

- [posterior intestine] Kristineberg, Sweden. Odhner (1902: 62).

— [rectum] Firth of Clyde, Scotland. Nicoll (1909: 16; 1910: 348).

— [rectum] Plymouth, Devon, England. Nicoll (1914: 483); Baylis \& Jones (1933: 630); Baylis (1939: 483).

[?] St Andrews, Scotland. McIntosh (1926: 54).

Myoxocephalus scorpius [?] Molengrat, Texel, Netherlands. Willemse (1968: 85).

Platichthys flesus [posterior intestine] Kristineberg, Sweden. Odhner (1902: 62).

- [rectum] Ythan estuary, Scotland. MacKenzie \& Gibson (1970: 4); Gibson (1972: 6).

- [rectum] Sea off Aberdeen. MacKenzie \& Gibson (1970: 4); Gibson (1972: 6).

- [rectum] Loch Ewe, Scotland. MacKenzie \& Gibson (1970: 4).

[rectum] Dee estuary, Scotland. Gibson (1972: 6).

- [posterior intestine, rectum] Øresund, Sweden. Køie (1976: 1).

[posterior intestine, rectum] Bergen, Norway. Køie(1976: 12).

[posterior intestine] SW coast of Sweden. Thulin (1981: 22).

Pleuronectes platessa [posterior intestine] Kristineberg, Sweden. Odhner (1902: 62).

- [rectum] St Andrews, Scotland. Nicoll (1907: 83).

[posterior intestine] Northumberland coast, England. Lebour (1908: 53).

[posterior intestine] Luce Bay, Irish Sea (Oct., 1908). Johnstone (1909: 191).

[rectum] Millport, Firth of Clyde, Scotland. Nicoll (1910: 348).

_ [rectum] Plymouth, Devon, England. Nicoll (1914: 483); Baylis \& Jones (1933: 630); Baylis (1939: 483);

Dawes (1947: 245).

- [rectum] Aberdeen, Scotland. Nicoll (1915: 360).

[intestine] Dale Fort, Dyfed, Wales. Crothers (1966: 23).

[rectum] Loch Ewe, Scotland. MacKenzie (1968: 13); MacKenzie \& Gibson (1970: 4).

- [rectum] Flamborough Head, German Bight and Southern Bight, North Sea. Wickins \& Macfarlane

(1973: 14).

- [rectum] Øresund, Sweden. Køie (1976: 1). 
Psetta maxima [rectum] St Andrews, Scotland. Nicoll (1907: 83).

Solea vulgaris [?] Kristineberg, Sweden. Odhner (1911a: 244).

— [intestine] Plymouth, Devon, England. Nicoll (1914: 483).

— [rectum] Whitstable, Kent, England. Maghraby \& Perkins (1956: 486).

[?] East Frisian waters. Lammert (1974: 149).

Taurulus bubalus [?] Cullercoasts, Northumberland, England. Crofton (1947: 62).

- [posterior intestine, rectum] Bergen, Norway. Køie (1976: 12).

Trachurus trachurus [?] Texel, Netherlands. Willemse (1968: 85).

Zeus faber [rectum] Plymouth, Devon, England. Nicoll (1914: 483).

\section{ASPECTS OF BIOLOGY}

Records of larval stages in the NE Atlantic:

(i) First intermediate host

Buccinum undatum [? 'the young distomes appear abundantly without tails in the sporocyst ... in the Buccinum undatum of our coast']-presumably Belgium. van Beneden (1876: 194, also 1875: $173=Z$. viviparus according to Køie, 1969: 261).

— [?] Boulogne, France. Pelseneer (1906: 170 as Cercaria giardi).

- ['digestive gland unhealthy pinkish yellow - cercariae in sporocysts occupying almost whole of spire of shell' sporocyst and cercaria 'almost certainly a larval stage of Zoogonus viviparus'.] presumably at Plymouth. Lebour (1918: 514).

— [digestive gland, gonad] Øresund, Sweden. Køie (1968: 21; 1969: 261; 1971: 165; 1974: 417; 1976: 3).

[?] ? Scotland. McNair, in DAFS (1972: 34).

[?] Heligoland. Lauckner (1973: 73; 1980: 374).

(ii) Second intermediate hosts

(a) Echinoderms

Leptosynapta inhaerens [peribuccal tentacles] Roscoff, Finistère, France. Cuénot (1892: 9 as Cercaria capriciosa).

Ophiothrix fragilis [gonads, viscera] Roscoff, Finistère, France. Cuénot (1892: 9 as Cercaria capriciosa).

Ophiura albida [gonads, viscera] Roscoff, Finistère, France. Cuénot (1892: 9 as Cercaria capriciosa).

— ['everywhere'] Øresund, Sweden. Køie (1976: 6 - most highly infested natural second intermediate host, also has been experimentally infested),

Ophiura robusta [?] Øresund, Sweden. Køie (1976: 6- one in 1 of 50 in area where $O$. albida is rarely infested).

Ophiura texturata [?] Øresund, Sweden. Køie (1976: 6 - naturally 1 in 1 of 20, also experimentally).

(b) Polychaetes

Ammotrypane aulogaster [?] West Kattegat. Køie (1976: 7-once).

Amphicteis gunneri [?] West Kattegat. Køie (1976: 7 -once).

Gattyana cirrosa [?] West Kattegat. Køie (1976: 7 - once).

Lagis koreni [?] Øresund, Sweden. Køie (1976: 7-naturally one or two in nearly half of 30, also experimentally).

Trochochaeta multisetosa [palps, anterior segments] Gullmar and Ellos Fjords, West Sweden. Orrhage (1973: 179).

various polychaetes [?] ? Scotland. McNair, in DAFS (1972: 34).

(c) Lamellibranch molluscs

(?) Lima hians [mantle edge] Millport, Firth of Clyde, Scotland. Nicoll \& Small (1909: 241; as Cercaria limae - see Lauckner, 1983: 690).

(?) Macoma baltica [?] Burry Inlet, South Wales. James, Sannia \& Bowers (1977: 13; as Metacercaria limae - see Lauckner, 1983: 690).

Nuculana minuta [?] Øresund, Sweden. Køie (1976: 7 - rarely, naturally and experimentally).

Nuculana pernula [mantle edge, occasionally in gills] Øresund, Sweden. Køie (1976: 7-naturally and experimentally).

(d) Gastropod molluscs

Cythara attenuata [mantle] West Kattegat. Køie (1976: 7 - in 2 of 20).

Lora turricula [mantle] West Kattegat. Køie (1976: 7 - in 8 of 40).

Nassarius incrassatus [mantle] West Kattegat. Køie (1976: 7 - in 1 of 30). 
(e) Crustaceans

(?) Mysis sp. [body-cavity] Roscoff, Finistère, France. Cuénot (1892: 9) believed that Villot's (1878: 30) record of Cercaria megalocotylea was possibly equivalent to his Cercaria capriciosa.

Lauckner (1973) and Køie (1976) also managed to infect a number of second intermediate hosts which were not found to harbour Z. viviparus naturally. Lauckner infected the echinoderm Psammechinus miliaris, while Køie infected the echinoderms Ophiura affinis, Amphiura filiformis, $A$. chiajei, Ophiocomina nigra and P. miliaris, the lamellibranchs Nucula sulcata, Modiola marmorata, Spisula subtruncata, Corbula gibba, Venus striatula and V. ovata and the gastropod Aporrhais pespelicani.

Køie (1980a) described the miracidium within the membranous non-operculate egg-capsule. The entire surface, apart from the apical papilla, is covered by a homogeneous layer of regularly arranged cilia. The next generation is found inside.

Mature daughter-sporocysts are found in the tissue between the tubules of the digestive gland, and released cercariae are most commonly found in this organ. The location of other cercariae suggests that it is possible that the cercariae leave the whelk through the mantle epithelium, distal to the kidney.

The tail-less cercaria, which bears a simple, pointed stylet, has been described by Lebour (1918) and Køie (1976). The ultrastructure and histochemistry were described by Køie (1971, 1974). On leaving the first intermediate host the cercariae creep, leech-like, using the posterior end and the oral sucker. The posterior end is distinctly sucker-like as can be seen in the scanning-electronmicrographs of Køie $(1971,1976)$. Under experimental conditions the cercariae were observed penetrating the polychaete Lagis koreni and, after bending ventrally, formed a thin, transparent spherical or oval cyst within less than an hour. The surface ultrastructure changes greatly in the first 40 days of the sojourn in the second intermediate host in that the microvilli atrophy and the spines become shorter, but the size of the worm does not alter during this period.

Cercaria zoogonoides Chubrik, 1966, from the gastropods Sipho islandicus and Buccinum finmarchianum from the Barents Sea could represent this species or possibly Pseudozoogonoides subaequiporus.

In general, the most important second intermediate hosts in the Øresund are ophiuroid echinoderms, particularly Ophiura albida, in which there is no apparent host-reaction to the parasite. Other echinoderms are only rarely infested. Køie (1976) suggested that polychaetes are probably important hosts only in regions where ophiuroids are rare, but it seems that many hosts of $Z$. viviparus apparently prey heavily on polychaetes and rarely pick up ophiuroids. Molluscs are generally poor hosts. The cercariae enter the ophiuroids mainly between the shields on the arms and encyst in all parts of the arms (as well as many other parts of the body) sometimes forming bulges. In the polychaete $L$. koreni, under experimental conditions, hundreds of cercariae were found, and heavily infested worms died within a day. Smaller infestations caused less damage, but sometimes granulomata were formed around the metacercariae. In the tubicolous polychaete Trochochaeta multisetosa, Orrhage (1973) found the metacercariae in the palps and anterior few segments only; this is the part of the body which is protruded from the tube and is therefore most liable to predation by fishes. In lamellibranchs (e.g. Nuculana pernula), although no host-reaction is evident, the metacercariae usually die and form hard, brown deposits.

Lauckner (1983) thought that 'in all probability, C. [ercaria] limae is the second larval stage of Zoogonoides viviparus'. This immature worm recorded in Lima hians from Millport, Scotland (Nicoll \& Small, 1909) and Macoma baltica from Burry Inlet, South Wales by James et al. (1977), has been considered a fellodistomid metacercaria by Nicoll \& Small (1909) and Bray \& Gibson (1980). The tegument lacks spines but the short saccular excretory vesicle, and the position of the cyst attached to the inner edge of the mantle cavity, suggest that Lauckner may be correct.

The adult normally occurs in the posterior intestine, and, particularly, the rectum of various teleosts (see fig. 14 of MacKenzie \& Gibson, 1970), lying deep between the irregular corrugations and adhering strongly with the ventral sucker. In the flounder (Platichthys flesus) they often lie close to the rectal valve which may serve to protect the worms from abrasion by gut-contents such as mollusc and echinoderm remains. In in vitro experiments Gibson (1971) found that $Z$. viviparus 

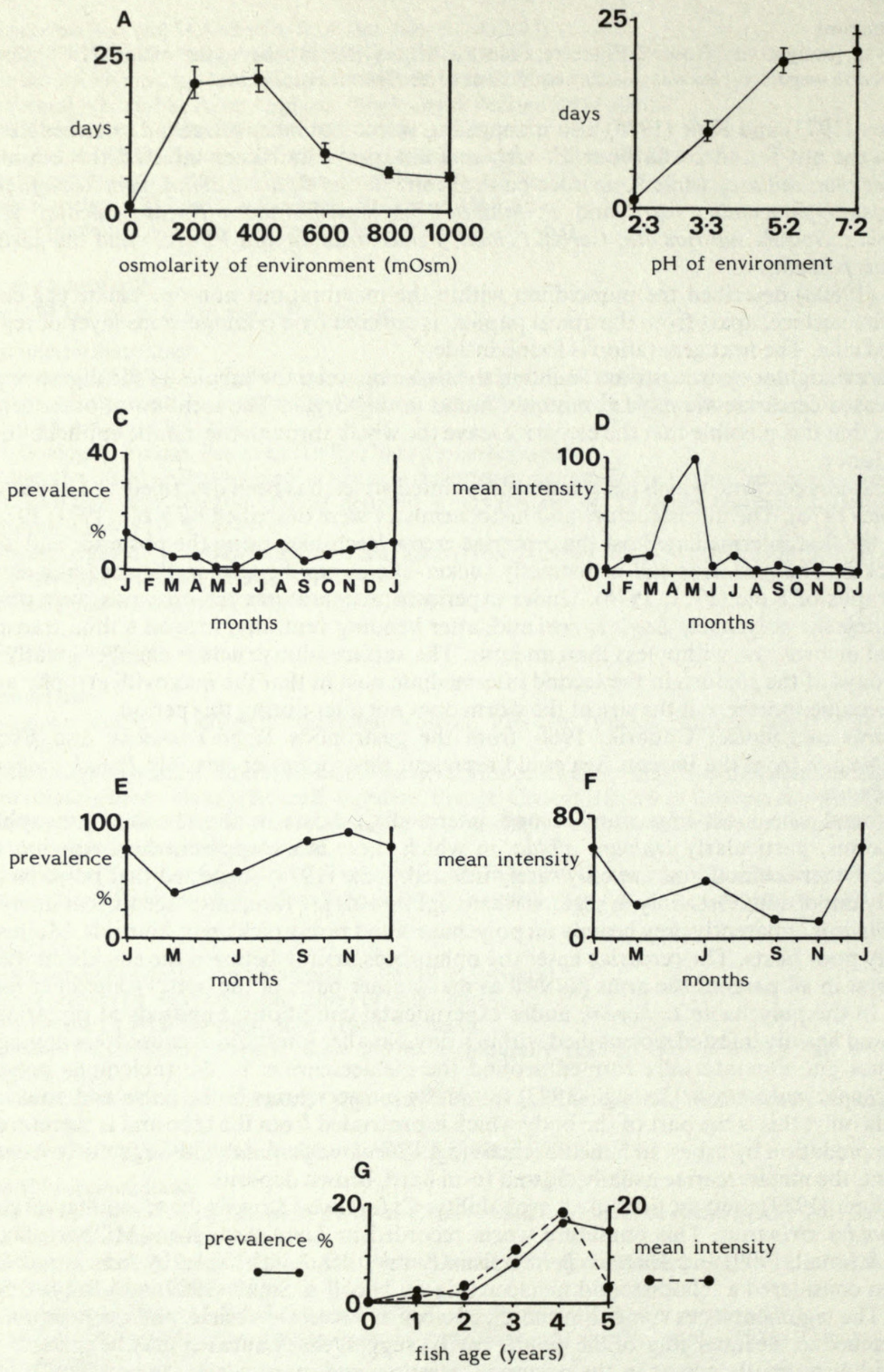

Fig. 9 Studies on Zoogonoides viviparus (Olsson) from Platichthys flesus, Scotland. (A) Osmolarity and survival in vitro; (B) $\mathrm{pH}$ and survival in vitro. (Error bars indicate twice the standard error of the mean survival); (C) Seasonal prevalence, Ythan estuary; (D) Seasonal mean intensity, Ythan estuary; (E) Seasonal prevalence, sea off Aberdeen; (F) Seasonal mean intensity, sea off Aberdeen; (G) Host-age and prevalence and mean intensity, Ythan estuary (After Gibson, 1971.) 
survives most successfully in osmolarities of between 200 and $400 \mathrm{mOsm}$ (Fig. 9A) and at a high pH (Fig. 9B), conditions which correspond to those found in the flounder rectum (Mackenzie \& Gibson, 1970). It is commonly found in flatfish, and a number of other teleosts, notably Callionymus (Callionymidae/Gobiesociformes), Zeus (Zeidae/Zeiformes), sculpins (Cottidae/ Scorpaeniformes), blennies (Blenniidae) and gobies (Gobiidae - both Perciformes). It appears that Callionymus spp. are among the preferred hosts. Frequently the rectum and the posterior third of the intestine of $C$. lyra is 'carpeted' with numerous (up to 800) specimens of Z. viviparus. We have found up to 416 in the flounder in the sea off Aberdeen, and in Danish waters nearly $100 \%$ of the Limanda limanda specimens are infested, with up to 200 per host (Køie, 1983). Its distribution includes the north Atlantic, Mediterranean, Barents and White Seas and the northern Pacific Ocean. It is recorded from Hippoglossoides platessoides in the north-west Atlantic by Scott (1973, 1975a,b), Umnova (1979) and Zubchenko (1980), but all our zoogonine specimens from this host in that area belong to Pseudozoogonoides subaequiporus (see Bray, 1979; as Diphterostomum microacetabulum) and Scott (1982) reidentified his material as D. microacetabulum. Some of the records from the Pacific Ocean may be questionable, e.g. Shimazu (1974) questioned the record of Isakova-Keo (1952), who recorded Z. viviparus from the cyprinid Leuciscus brandti, believing these specimens to be close to his species Pseudozoogonoides ugui. The other two descriptions of the north Pacific form, those of Zhukov (1960) and Ichihara et al. (1966), also suggest that a different species may be involved in the northern Pacific records, e.g. both descriptions show that the caeca pass the testes, and the testes are well forward. Køie (1983) pointed out that Buccinum undatum does not occur in the North Pacific. Thus it may be that the northern Pacific form is different to that of the north Atlantic and should be carefully compared with Zoogonoides acanthogobii Yamaguti, 1938 and Z. yamagutii Kamegai, 1973.

Gibson (1972) showed that $Z$. viviparus has a higher prevalence in marine than in estuarine flounders, and was able to utilize this species as an indicator (tag) of the area of origin of the flounders. It has 'very high' prevalence in the sea off Aberdeen but 'very low' prevalence in the estuary he investigated in detail, the Ythan at Newburgh, Grampian region of Scotland. Results for these localities, along with three others (Gibson, 1971) are given in Table 7. In contrast to those in the sea, the estuarine flounders show low levels of prevalence and intensity throughout the year (Fig. 9C,D) (although one or two fishes of marine origin probably exert an influence on March to May figures in Fig. 9D). The results from marine flounders (Fig. 9E,F) suggest that their main period of parasite acquisition is in the autumn, and as the estuarine flounders pass into the sea in spring to spawn, they are not exposed to the peak period of parasite acquisition and, although most of their $Z$. viviparus burden is acquired at this time they never have the opportunity to build up higher intensity levels. The presence of estuarine flounders in the sea in spring probably influences the spring data (Fig. 9E) accounting partly for the spring drop. The reasons for the low prevalence in the estuary may well be connected with the rarity of Buccinum undatum. Ophiuroids were not found in the diet of the Ythan estuary flounders. Køie (1983) found that the dabs from Køge Bay,

Table 7 Zoogonoides viviparus in Platichthys flesus

\begin{tabular}{lccccc}
\hline Locality & $\begin{array}{l}\text { No. of fish } \\
\text { examined }\end{array}$ & $\begin{array}{l}\text { No. } \\
\text { infested }\end{array}$ & $\begin{array}{l}\text { Percentage } \\
\text { prevalence }\end{array}$ & $\begin{array}{l}\text { No. of } \\
\text { parasites }\end{array}$ & $\begin{array}{l}\text { Mean } \\
\text { intensity }\end{array}$ \\
\hline Ythan estuary & 740 & 45 & 6 & 598 & $13 \cdot 3$ \\
Sea off Aberdeen & 170 & 116 & 68 & 3622 & $31 \cdot 2$ \\
River Dee & 50 & 8 & 16 & $494^{*}$ & $61 \cdot 7^{*}$ \\
Plymouth & 42 & 18 & 43 & 464 & $25 \cdot 8$ \\
Loch Ewe & 7 & 6 & 86 & 52 & $8 \cdot 7$ \\
\hline
\end{tabular}

*As pointed out by Gibson (1972), this figure is distorted by the presence in the Dee estuary of a marine flounder containing 361 specimens. 
at the Baltic end of the Øresund, were not infested with Z. viviparus whereas at all her other, more marine, stations there was a high prevalence. Køie (1969) showed that the infestation of B. undatum in the Øresund is lowest in December and rises in spring, and Gibson's (1971) data agree with this, in that presumably the cercarial production builds up during spring and summer, and the metacercarial population builds up during summer and autumn. Host-age effects (Fig. 9G) suggest that the parasite intensity increases after the flounder has fed on copepods and while it is of the size to feed on annelids, but decreases when the flounder diet changes to include more molluscs and small fish.

PREVIOUS DESCRIPTIONS. Olsson (1868: 28); Odhner (1902: 62; 1911 $a$ : 243); Nicoll (1907: 83; 1909a: 16); Lebour (1908: 53); Johnstone (1909: 191); Køie (1976: 11); [Zhukov (1960: 29); Ichihara et al. (1966: 4)].

DESCRIPTION (Figs 3d, 10). Over 200 specimens were studied (including two in serial sections). The measurements are given in Table 8. Unflattened, the worms are fusiform (Fig. 10A,B): flattening of these very small trematodes, although sometimes useful for particular purposes, distorts the overall morphology. The tegument bears small spines in transverse rows in the forebody, down to about the level of the ventral sucker. The oral sucker is subterminal, globular and leads into a short prepharynx and thence to a small globular to oval pharynx. The distinct oesphagus is straight or slightly sinuous. It bifurcates just inside the posterior half of the forebody. The caecal length varies, reaching to a level just anterior to the testes and the posterior edge of the ventral sucker or just overlapping the testes either slightly or considerably, up to the posterior edge of the testes or just
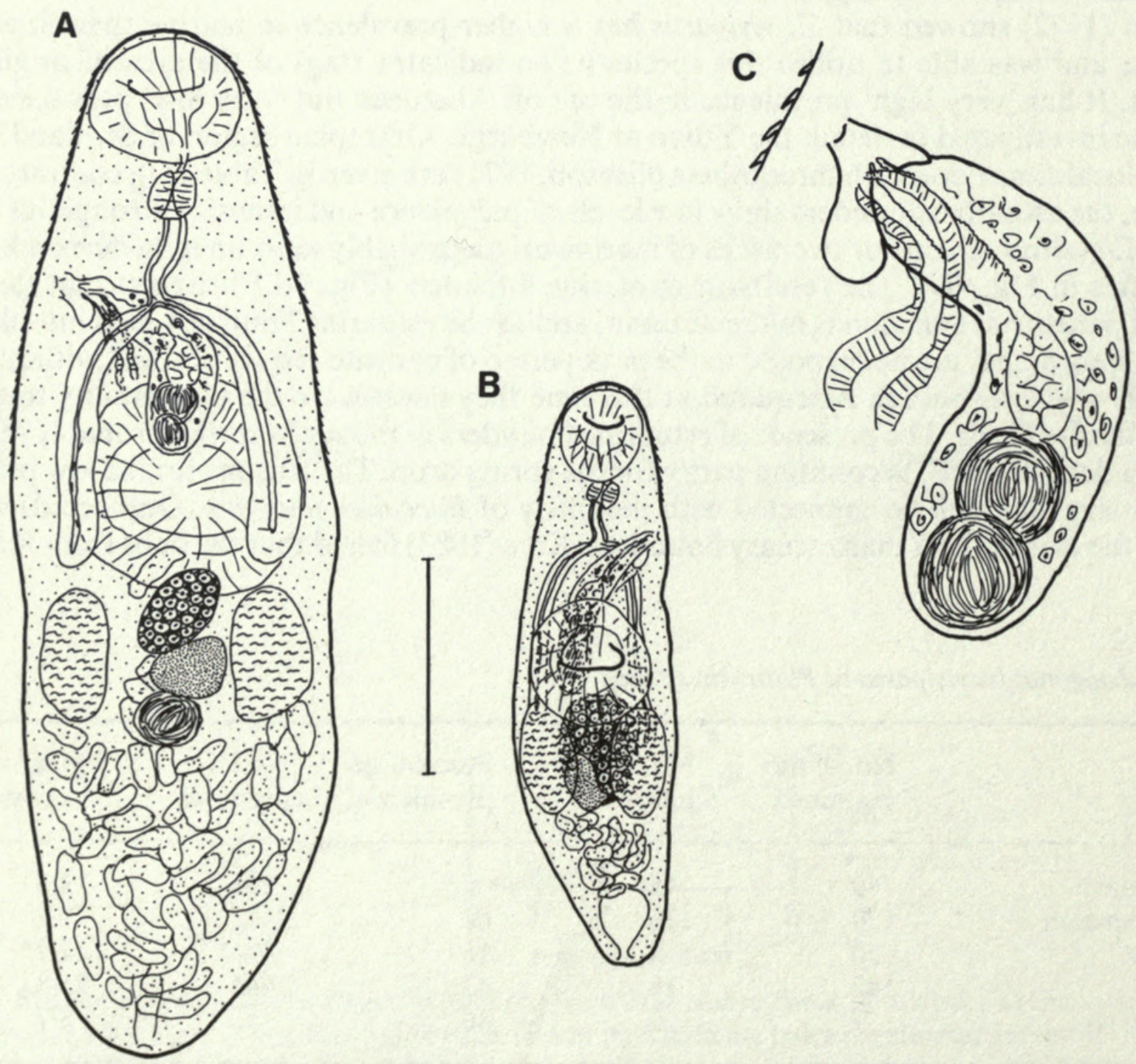

Fig. 10 Zoogonoides viviparus (Olsson). (A) Dorsal view, ex Callionymus lyra; (B) Ventral view, ex Pomatoschistus minutus; (C) Terminal genitalia. Scale bars: A, B $0 \cdot 2 \mathrm{~mm}$. 
Table 8 Measurements of Zoogonoides viviparus

\begin{tabular}{|c|c|c|c|c|}
\hline Host & $\begin{array}{l}\text { Callionymus } \\
\text { lyra }\end{array}$ & $\begin{array}{l}\text { Zeus } \\
\text { faber }\end{array}$ & $\begin{array}{l}\text { Pomatoschistus } \\
\text { minutus }\end{array}$ & Flatfish \\
\hline Length (mm) & $0.69-1.46$ & $0.42-0.90$ & $0.40-0.54$ & $0.31-0.93$ \\
\hline Breadth $(\mathrm{mm})$ & $0.24-0.34$ & $0 \cdot 18-0 \cdot 28$ & $0 \cdot 10-0 \cdot 15$ & $0.13-0.34$ \\
\hline $\begin{array}{l}\text { Length : forebody } \\
\text { ratio }\end{array}$ & $1: 0.30-0.42$ & $1: 0.33-0.40$ & $1: 0.27-0.37$ & $1: 0 \cdot 26-0 \cdot 50$ \\
\hline Oral sucker (mm) & $\begin{array}{r}0 \cdot 12-0 \cdot 14 \times \\
0 \cdot 11-0.14\end{array}$ & $\begin{array}{c}0 \cdot 12-0 \cdot 13 \times \\
0 \cdot 11\end{array}$ & $\begin{array}{c}0.07-0.09 \times \\
0.08\end{array}$ & $\begin{array}{r}0.07-0.13 \times \\
0.07-0.14\end{array}$ \\
\hline $\begin{array}{l}\text { Ventral sucker } \\
(\mathrm{mm})\end{array}$ & $\begin{array}{r}0.17-0.22 \times \\
0.15-0.22\end{array}$ & $\begin{array}{l}0.19 \times \\
0.16-0.17\end{array}$ & $\begin{array}{r}0 \cdot 12-0 \cdot 14 \times \\
0.09-0.11\end{array}$ & $\begin{array}{r}0 \cdot 11-0 \cdot 27 \times \\
0 \cdot 10-0 \cdot 22\end{array}$ \\
\hline Sucker-ratio & $1: 1 \cdot 36-1 \cdot 60$ & $1: 1 \cdot 45-1 \cdot 54$ & $1: 1 \cdot 125-1 \cdot 37$ & $1: 1 \cdot 10-2 \cdot 00$ \\
\hline Pharynx (mm) & $\begin{array}{l}0.04-0.06 \\
\text { diam. }\end{array}$ & $\begin{array}{l}0.04-0.05 \\
\text { diam. }\end{array}$ & $\begin{array}{l}0.03-0 \cdot 04 \\
\text { diam. }\end{array}$ & $\begin{array}{c}0.03-0.06 \\
\text { diam. }\end{array}$ \\
\hline Oesophagus (mm) & $0.05-0.08$ & 0.06 & 0.04 & $0 \cdot 02-0 \cdot 10$ \\
\hline Cirrus-sac (mm) & $\begin{array}{l}\text { straight } \\
0 \cdot 18-0 \cdot 24 \\
\text { recurved* } \\
\text { (A) } 0 \cdot 14-0 \cdot 17 \\
\text { (B) } 0 \cdot 11-0.14 \times \\
0.04-0.07\end{array}$ & - & $\begin{array}{l}\text { straight } \\
0 \cdot 15 \\
\text { recurved* } \\
\text { (A) } 0 \cdot 11 \\
\text { (B) } 0 \cdot 10 \times \\
0 \cdot 03-0 \cdot 04\end{array}$ & $\begin{array}{l}\text { straight } \\
0.14-0.21 \\
\text { recurved* } \\
\text { (A) } 0.09-0.18 \\
\text { (B) } 0.07-0.15 \times \\
0.03-0.06\end{array}$ \\
\hline Testes (mm) & $\begin{array}{r}0 \cdot 10-0 \cdot 15 \times \\
0.06-0.11\end{array}$ & $\begin{array}{c}0 \cdot 10-0 \cdot 11 \times \\
0 \cdot 07\end{array}$ & $\begin{array}{r}0.09-0.11 \times \\
0.04-0.05\end{array}$ & $\begin{array}{r}0.05-0.13 \times \\
0.03-0.08\end{array}$ \\
\hline Ovary (mm) & $\begin{array}{r}0.05-0.12 \times \\
0.05-0.09\end{array}$ & $0.08 \times 0.07$ & $\begin{array}{r}0.09-0.10 \times \\
0.06-0.08\end{array}$ & $\begin{array}{r}0.05-0.10 \times \\
0.04-0.08\end{array}$ \\
\hline Miracidium $(\mu \mathrm{m})$ & $60-70 \times 25-36$ & $62 \times 25$ & $52 \times 20$ & $45-82 \times 17-62$ \\
\hline
\end{tabular}

*Recurved cirrus-sac length measured in two parts: (A) distal part, (B) proximal part.

beyond. The ventral sucker is larger that the oral sucker in the ratio $1: 1 \cdot 1-2 \cdot 0$. It lies just anterior to the middle of the body. It is strongly muscular and not quite circular, with a transversely oval aperture.

The terminal excretory pore leads via a narrow duct into a small, oval vesicle which just overlaps the uterus.

The oval testes lie symmetrically to slightly obliquely just posterior to or at the posterior margin of the ventral sucker with their long axes lying longitudinally. The vasa efferentia were not traced. The cirrus-sac is claviform and variable in that it may lie straight or be strongly or weakly reflexed, normally overlapping the ventral sucker almost to its middle. It contains a small, bipartite seminal vesicle, a short, wide, oval, vesicular pars prostatica and a long, muscular, wide, annularly wrinkled ejaculatory duct - all surrounded by numerous gland cells (Fig. 10C). Often the lining of the ejaculatory duct has been described as spined. Close examination of sections under oil immersion does not clearly show whether tiny spines are present or whether small papillae of the ejaculatory duct lining extend into the lumen. It is possible that the spine-like effect is the result of the wrinkling in the ejaculatory duct which occurs when it is withdrawn. If the cirrus-sac is reflexed the bend occurs at about the junction of the pars prostatica and ejaculatory duct or further posteriorly. It opens into a distinct genital atrium, which in turn opens via the genital pore close to or on the left lateral margin about half-way between the suckers. There is a distinct sac-like diverticulum (atrial sac) leading posteriorly from the genital atrium (Fig. 3D). The function of this is not obvious, but a similar structure is referred to as an 'accessory seminal receptacle' by Arai (1954).

The oval ovary is usually just smaller than the testes, just overlapping the posterior margin of the ventral sucker and between the testes. The long axis tends to lie diagonally. The oviduct passes posteriorly and receives the ducts of the seminal receptacle and the vitellarium. No Mehlis' gland 


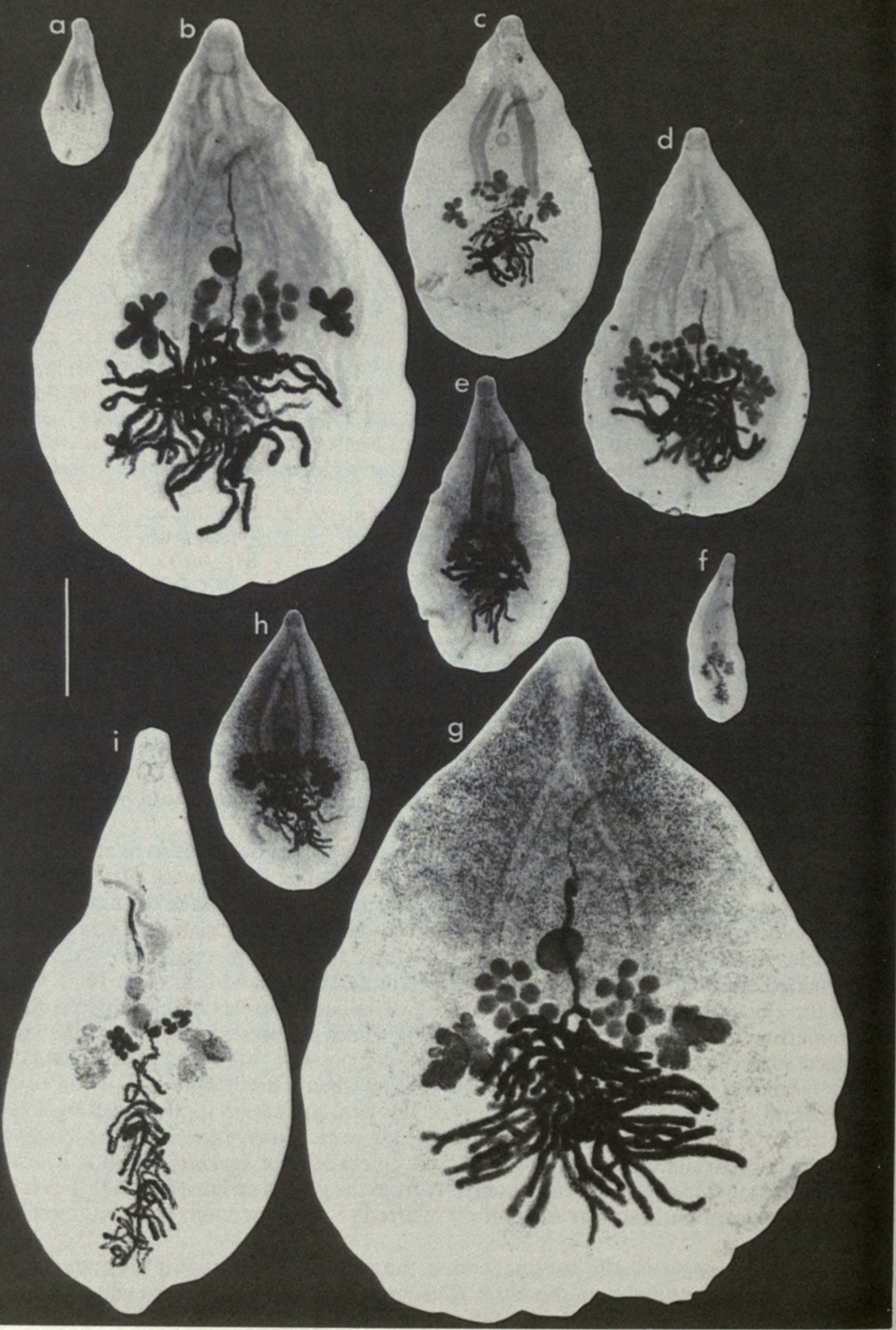


was detected. The canalicular seminal receptacle is globular. Laurer's canal apparently arises at or near the proximal end of the seminal receptacle and passes posteriorly opening dorsally, posteriorly to the seminal receptacle. The bulk of the hindbody is filled with the uterus containing the developing miracidia each enclosed in a thin membranous capsule. No shell is developed. The metraterm is strongly muscular and is ensheathed with gland cells distally. It opens into the genital atrium dorsally to the cirrus-sac. Between the seminal receptacle and the ovary lies the subglobular, oval or slightly irregular single vitelline mass.

Discussion. Of the species mentioned in the synonymy, Distoma callionymi and Cercaria megalocotylea are too poorly known to be definitely considered synonyms, but in the former case the host suggests that the synonymy is likely. The status of this species is fairly straightforward, but the possibility of its confusion with Pseudozoogonoides subaequiporus (see pp. 147, 157) should be stressed

\section{Subfamily LEPIDOPHYLLINAE Stossich, 1903}

\section{Key to the genera of the Lepidophyllinae from the north-east Atlantic}

1 Body flattened, spatulate. Testes deeply lobed. Excretory pore subterminal. In urinary bladder Lepidophyllum Odhner, 1902 (p. 160)

- Body more or less oval or rounded in cross-section. Oval to pyriform or fusiform in ventral view.

Testes more or less entire. Excretory pore terminal. Not usually found in urinary bladder . . 2

2 Caeca short, saccular or not, reaching into hindbody . . . . . . . . . . . . . . . . . 3

- Caeca reaching to testes or beyond.

3 Testes overlapping ventral sucker into forebody. Ovary post-testcular. Vitellarium in forebody

Panopula Overstreet \& Pritchard, 1977 (p. 171)

- Testes not reaching into forebody. Ovary pre-testicular. Vitellarium at or near level of ventral sucker of posterior forebody

4 Ventral sucker divided equatorially by ridge or row of large papillae .

Brachyenteron Manter, 1934 (p. 175)

- Ventral sucker undivided .

Steganoderma $\mid$ Stafford, 1904 (p. 193)

5 Ventral sucker divided equatorially by internal (ventral) ridge and external (dorsal) cleft

- Row of large papillae across internal equator of ventral sucker. No dorsal cleft

Steganodermatoides Parukhin \& Lyadov, 1979 (p. 181)

6 Genital atrium large, pocketed. Periatrial gland undivided, massive, also enveloping distal regions of metraterm and cirrus-sac

Neosteganoderma Byrd, 1964 (p. 185)

- Genital atrium small, tubular. Periatrial gland divided into separate, claviform sacs .

Proctophantastes Odhner, 1911 (p. 189)

\section{Genus LEPIDOPHYLLUM Odhner, 1902}

Paralepidophyllum Yamaguti, 1934.

DIAGNOSTIC FEATURES. Body broadly pyriform; strongly flattened dorso-ventrally. Body surface spinous. Oral sucker small. Oesophagus distinct. Caeca reach into hindbody to level of vitellaria or testes. Ventral sucker small, rounded, in anterior half of body. Symmetrical lobed testes in mid to anterior hindbody. Cirrus-sac narrow, elongate. Seminal vesicle bipartite. Pars prostatica long. Genital pore sinistral, dorsally submarginal or marginal; mid to anterior forebody. Ovary oval to slightly lobed, in anterior hindbody. Eggs tanned, operculate. Filaments of egg-shell material may occur in uterus. Uterus mainly post-testicular. Vitellarium two groups each of about 9-13 follicles, laterally in anterior hindbody. Excretory pore dorsally subterminal, vesicle elongate sac in posterior hindbody. In urinary bladder of teleosts.

Fig. 11 (left). Lepidophyllum steenstrupi Odhner. Photomicrographs of specimens showing variation, all to same scale. ex Anarhichas lupus: (a) NE Scotland; (b) Faeroes; (c) Tromsø; (e) Nova Scotia; (g) Newfoundland: (h) Anton Dohrn Bank; (i) Passamaquoddy Bay. ex Anarhichas minor; (d) IcelandFaroes Channel; (f) Anton Dohrn Bank. Scale bar: $1 \mathrm{~mm}$. 


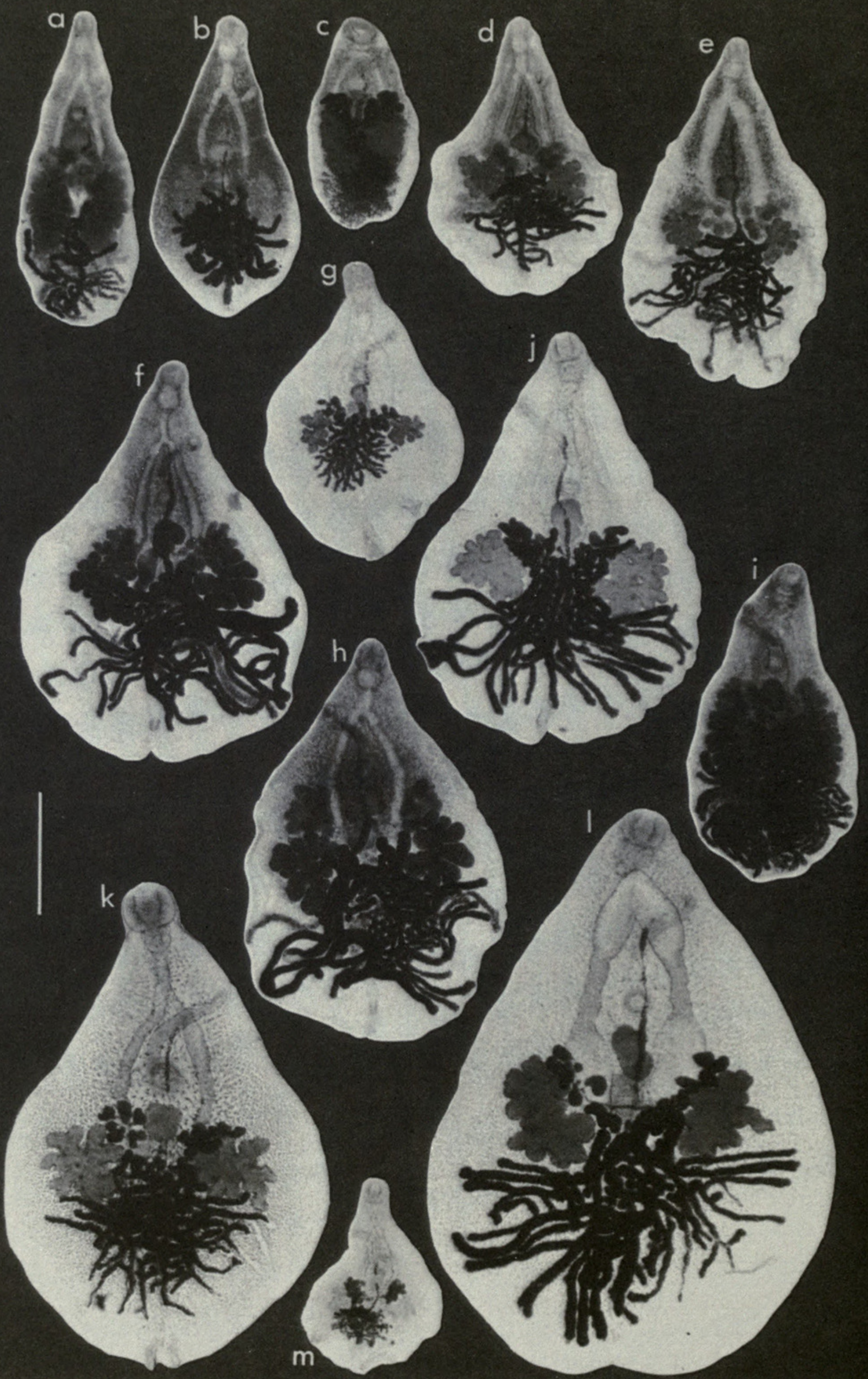




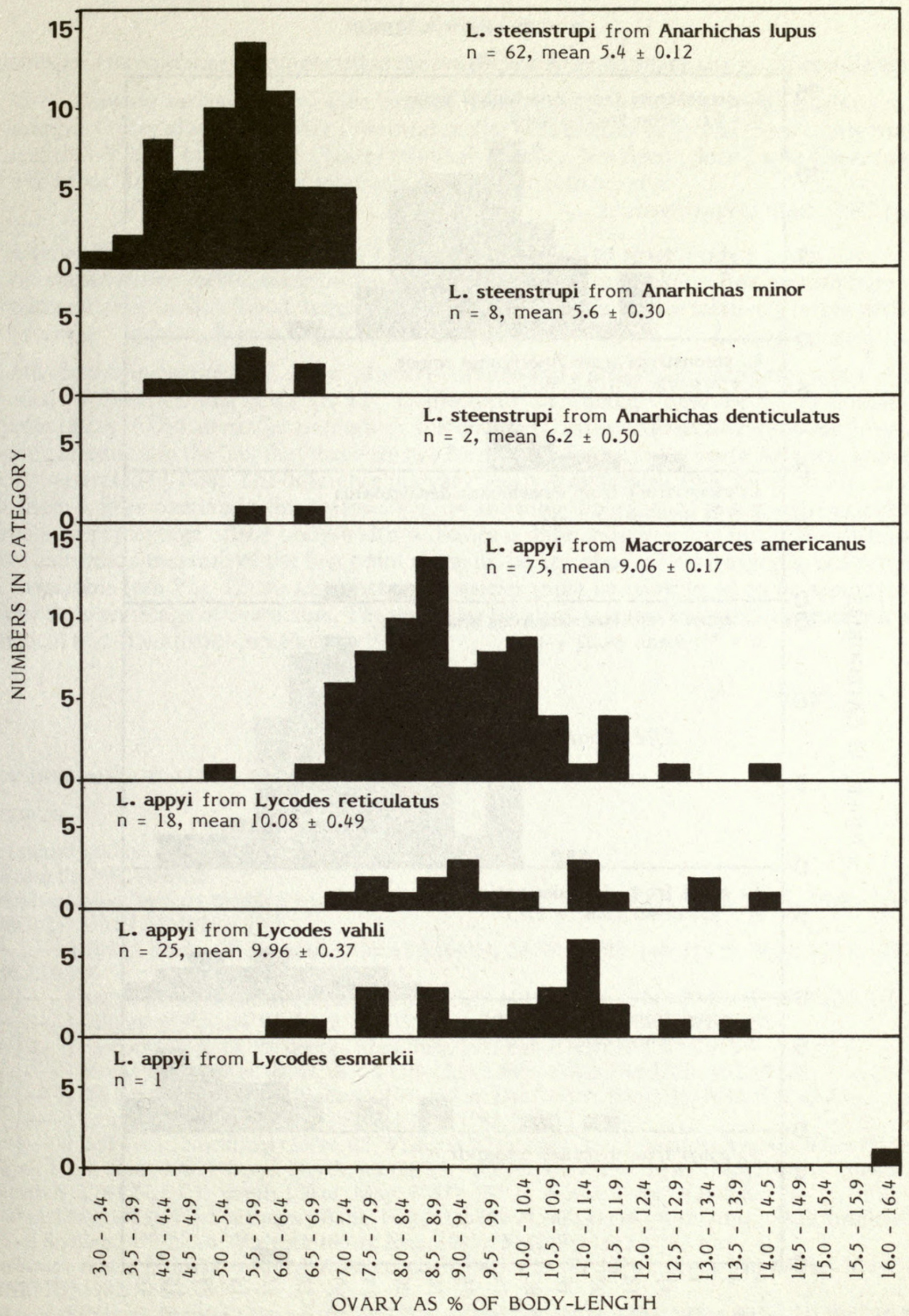

Fig. 13 Lepidophyllum steenstrupi and L. appyi, the length of the ovary as a percentage of body-length.

Fig. 12 (left). Lepidophyllum appyi sp. nov. Photomicrographs of specimens to show variation, all to same scale. ex Lycodes vahli: (a), (f), (h), (i) Newfoundland; (m) Gulf of St Lawrence. ex Macrozoarces americanus: (b), (k) Passamaquoddy Bay; (g) Gulf of St Lawrence. ex Lycodes esmarkii: (c) NW Scotland. ex Lycodes reticulatus: (d) Newfoundland; (e), (j), (l) Scotian Shelf. Scale bar: $1 \mathrm{~mm}$. 


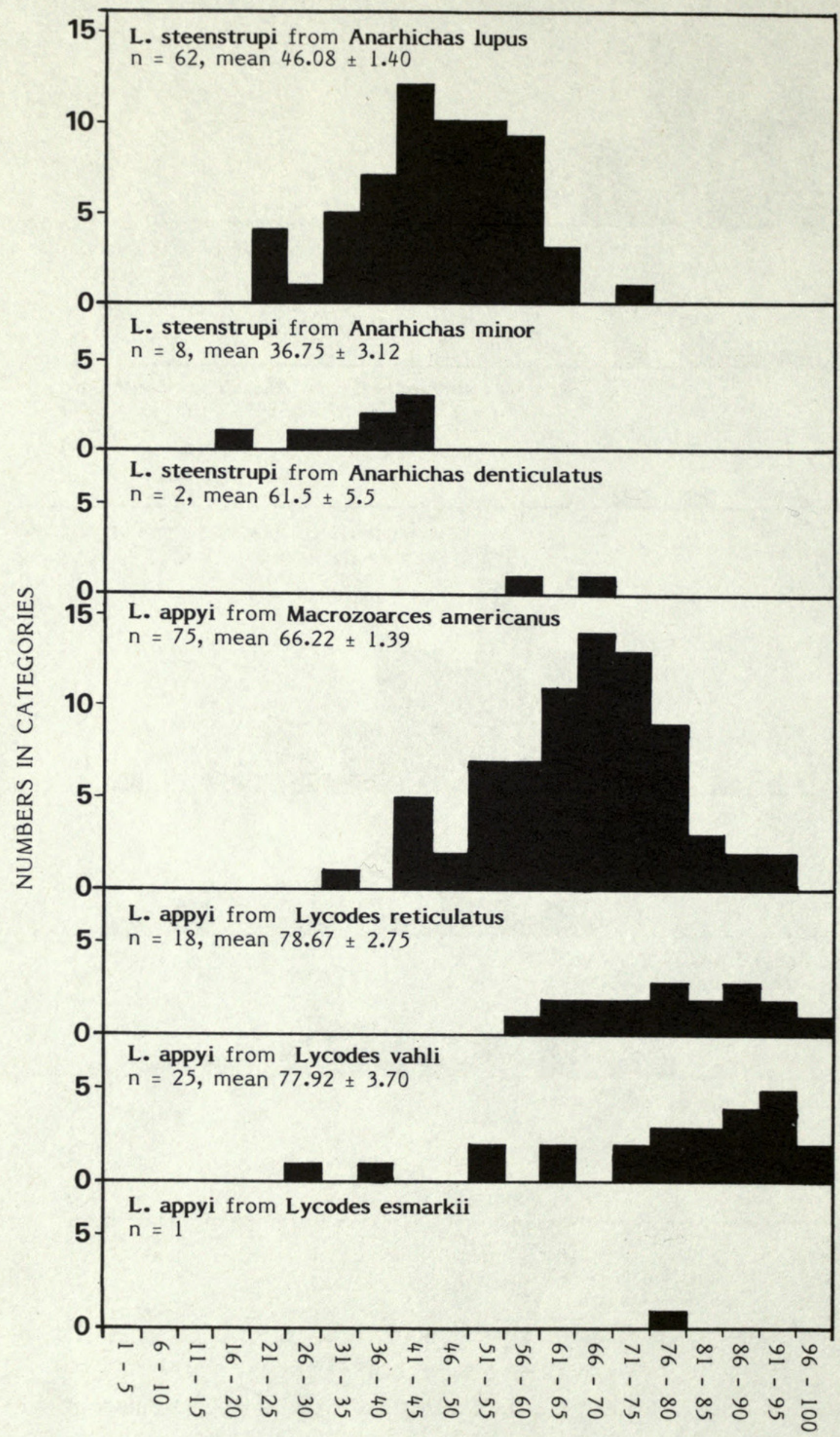

UTERUS AS \% OF BODY-WIDTH

Fig. 14 Lepidophyllum steenstrupi and L. appyi, the uterus as a percentage of body-width. 
Comments. Two species are recognized in the north-east Atlantic which can be differentiated thus:

(a) Uterus always surrounded by wide band of parenchyma - no uterine slings reaching to body margin. Ovary always posterior to ventral sucker with distinct gap; oval to smoothly rounded; length 3-7\% of body length. Testes relatively smaller, less deeply lobed with fewer (average 5.6) lobes. Spines distinct but relatively small. In Anarhichas spp .

L. steenstrupi Odhner, 1902 (p. 165)

(b) Uterus fills post-testicular region, or single slings tend to reach body-margin. Ovary often overlaps ventral sucker, close to or contiguous with ventral sucker; often smooth but may be distinctly but weakly lobed, length $7-14 \%$ of body length. Testes relatively larger with more (average 7.7) lobes. Spines larger. In zoarcid teleosts .

L. appyi sp. nov. (p. 168)

Both species, in particular L. appyi, are very variable and a series of microphotographs of each is included to illustrate this (Figs 11, 12). Conjectures on whether these forms are host-induced varieties (Bray, 1979) are rather premature. It seems most useful to erect a new species, in so doing drawing attention to the fact that there are two forms to be found in the north Atlantic, apparently strictly separated by host. The difference in ovary : body-length ratio, illustrated on Fig. 13 shows that there is little overlap in this feature. Fig. 14 showing the width of the extreme extent of the uterus as a percentage of the body-width indicates a difference which is much less distinct, but serves as a crude measure of the first point made in the key above. This feature is, unfortunately, not invariable (see Fig. 12) so that these two species must be considered to be separated by a polythetic assemblage of characters. The testicular lobation is statistically different using a simple statistical test (d-statistic - see Parker, 1973).

\section{Lepidophyllum steenstrupi Odhner, 1902}

TYPE-HOST AND LOCALITY. Anarhichas minor, Iceland.

\section{RECORDS}

(i) Material studied

(a) From the NE Atlantic

Anarhichas lupus [urinary bladder] east coast of Iceland $\left(66^{\circ} \mathrm{N}, 13^{\circ} \mathrm{W}\right.$; depth $119 \mathrm{~m}$; Aug., 1948). (see Rees, 1953: 21). $\mathrm{BM}(\mathrm{NH})$ 1976.4.9.17.

$[-]$ Eldey Bank, off Reykjanes, Iceland $\left(64^{\circ} \mathrm{N}, 24^{\circ} \mathrm{W}\right.$; depth $148-152 \mathrm{~m}$; May, 1974). BM(NH) 1982.10.8.1.

- - $]$ Anton Dohrn Bank ( $65^{\circ} \mathrm{N}, 30^{\circ} \mathrm{W}$; depth 370-440 m; May, 1974). BM(NH) 1982.10.8.2-6.

- - - Orkneys $\left(59^{\circ} \mathrm{N}, 04^{\circ} \mathrm{W}\right.$; depth $164-172 \mathrm{~m}$; July, 1976). BM(NH) 1982.10.8.7.

- - - Faeroes $\left(62^{\circ} \mathrm{N}, 08^{\circ} \mathrm{W}\right.$; depth $112 \mathrm{~m}$; July, 1976). BM(NH) 1982.10.8.9.

- - - Moray Firth $\left(58^{\circ} \mathrm{N}, 02^{\circ} \mathrm{W}\right.$; depth $150-152 \mathrm{~m}$; July, 1976). BM(NH) 1982.10.8.8.

- [ - NE Scotland $\left(59^{\circ} \mathrm{N}, 01^{\circ} \mathrm{E}\right.$; depth $107-117 \mathrm{~m}$; Dec., 1979). BM(NH) 1982.10.8.10-13.

- [- Tromsø, Norway (June, 1980). BM(NH) 1982.10.8.14.

- - ] Bell Rock, North Sea $\left(56^{\circ} \mathrm{N}, 02^{\circ} \mathrm{W}\right.$; depth $52 \mathrm{~m}$; May, 1982); Swatchway, North Sea $\left(57^{\circ} \mathrm{N}, 00^{\circ}\right.$; depth $80 \mathrm{~m}$; June, 1982); Beryl, North Sea $\left(60^{\circ} \mathrm{N}, 02^{\circ} \mathrm{E}\right.$; depth $118 \mathrm{~m}$; June, 1982); NW of Ninian Field, North Sea $\left(61^{\circ} \mathrm{N}, 01^{\circ} \mathrm{E}\right.$; depth $150 \mathrm{~m}$; May, 1983); SW of Ninian Field, North Sea $\left(61^{\circ} \mathrm{N}, 01^{\circ} \mathrm{E}\right.$; depth $140 \mathrm{~m}$; May, 1983); West of Bressay Bank, North Sea $\left(59^{\circ} \mathrm{N}, 00^{\circ}\right.$; depth $140 \mathrm{~m}$; June, 1983); Strathey Point, N. of Scotland $\left(59^{\circ} \mathrm{N}, 04^{\circ} \mathrm{W}\right.$; depth $100 \mathrm{~m}$; June, 1983). BM(NH) 1983.11.23.16.

Anarhichas minor [urinary bladder] Anton Dohrn Bank $\left(65^{\circ} \mathrm{N}, 30^{\circ} \mathrm{W}\right.$; depth $370-440 \mathrm{~m}$; May, 1974). $\mathrm{BM}(\mathrm{NH})$ 1982.10.8.15.

- [ - ] Iceland-Faeroes Channel $\left(63^{\circ} \mathrm{N}, 11^{\circ} \mathrm{W}\right.$; depth $410-420 \mathrm{~m}$; June, 1974). BM(NH) 1982.10.8.16.

(b) From elsewhere

Anarhichas denticulatus [urinary bladder] Newfoundland. Material of Bray (1979: 418). BM(NH) 1977.2.15.139.

Anarhichas lupus [urinary bladder] Newfoundland and Nova Scotia. Material of Bray (1979: 418). BM(NH) 1977.2.15.112-138.

- [ ] Passamaquoddy Bay, New Brunswick (May, 1976). Collector R. Appy. BM(NH) 1983.3.16.27. 
(ii) NE Atlantic records from the literature

Anarhichas lupus [urinary bladder] Trondheim, Norway. Odhner (1911a: 240).

- [- $]$ Kristineberg, Sweden. Odhner (1911a: 240).

[- ] east coast of Iceland. Rees (1953: 21).

- [- gall-bladder] Neskaupstadur and Húsavík, Iceland. Brinkmann (1956: 15).

Anarhichas minor [urinary bladder] Iceland. Odhner (1902: 68: 1911a: 240).

- [- $]$ Neskaupstadur and Húsavík, Iceland. Brinkmann (1956: 15).

AsPeCTS OF BIOLOGY. Little is known of the life-cycle of this species. It develops from a narrow lanceolate form (Figs 12a,f, 15B) to a wide, spatulate form (Figs 12b,g, 15A) while within the urinary bladder (see also Brinkmann, 1975). The route of entry to the urinary bladder is not known. Specimens have not been detected in the intestine or the ureter, but the opening of the urinary bladder is distinct from the anus so the latter seems the more likely point of entry. A record of a single specimen in the gall-bladder is given by Brinkmann (1956). This worm is known exclusively from Anarhichas spp.; records from Macrozoarces americanus (see Stafford, 1904; 1907; Cooper, 1915: Linkletter et al., 1977) and Lycodes spp. (see Bray, 1979) are considered to represent a separate but closely related species, L. appyi. L. steenstrupi is restricted to the North Atlantic Ocean and the Barents and White Seas.

PREVIOUS DESCRIPTIONS. Odhner (1902: 68; 1911a: 240); Stafford (1904: 487); Miller (1941: 47); Rees (1953: 21); Brinkmann (1975: 43).

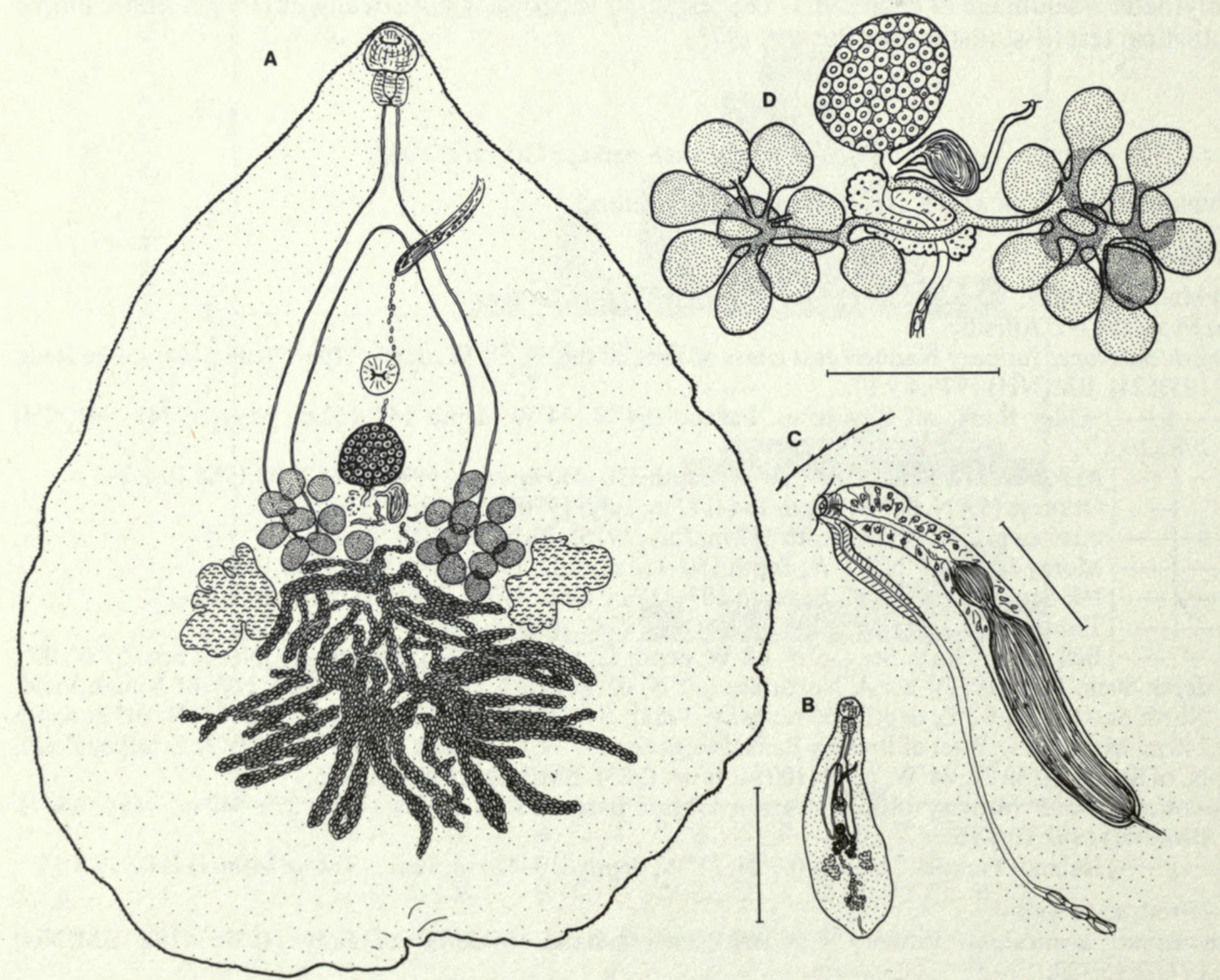

Fig. 15 Lepidophyllum steenstrupi Odhner. (A) Ventral view, ex Anarhichas lupus; (B) Ventral view, ex A. minor; (C) Terminal genitalia; (D) Proximal female genitalia. Scale bars: A, B 1 mm, C 0.2 mm. D. $0.5 \mathrm{~mm}$. 
Table 9 Measurements of Lepidophyllum steenstrupi

\begin{tabular}{|c|c|c|c|c|}
\hline Authority & Odhner (1902) & & Present study & \\
\hline Host & $\begin{array}{l}\text { Anarhichas } \\
\text { minor }\end{array}$ & $\begin{array}{l}\text { Anarhichas } \\
\text { lupus }\end{array}$ & $\begin{array}{l}\text { Anarhichas } \\
\text { minor }\end{array}$ & $\begin{array}{l}\text { Anarhichas } \\
\text { denticulatus }\end{array}$ \\
\hline Locality & Iceland & see text & see text & see text \\
\hline Number studied & - & 62 & 8 & 2 \\
\hline Length (mm) & $2 \cdot 1-2 \cdot 4$ & $0.92-5.45$ & $1 \cdot 45-3 \cdot 1$ & $3 \cdot 85-4 \cdot 68$ \\
\hline Breadth $(\mathrm{mm})$ & $1 \cdot 1-1 \cdot 4$ & $0 \cdot 49-3 \cdot 3$ & $0.47-1.83$ & $1 \cdot 9-2 \cdot 1$ \\
\hline $\begin{array}{l}\text { Length : forebody } \\
\text { ratio }\end{array}$ & {$[1: 0 \cdot 34]^{*}$} & $1: 0 \cdot 31-0 \cdot 40$ & $1: 0.37-0.46$ & $1: 0 \cdot 32$ \\
\hline Oral sucker (mm) & c. $0 \cdot 18$ diam. & $\begin{array}{r}0 \cdot 11-0.24 \times \\
0.12-0.28\end{array}$ & $\begin{array}{r}0 \cdot 11-0 \cdot 17 \times \\
0 \cdot 12-0.18\end{array}$ & $\begin{array}{r}0 \cdot 21-0 \cdot 22 \times \\
0 \cdot 23-0.24\end{array}$ \\
\hline $\begin{array}{l}\text { Ventral sucker } \\
(\mathrm{mm})\end{array}$ & c. $0 \cdot 17$ diam. & $\begin{array}{r}0.09-0.19 \times \\
0.09-0.20\end{array}$ & $\begin{array}{r}0 \cdot 11-0 \cdot 17 \times \\
0 \cdot 10-0.17\end{array}$ & $\begin{array}{r}0.20-0.23 \times \\
0 \cdot 20-0.23\end{array}$ \\
\hline Sucker-ratio & [c. $1: 0.94]$ & $1: 0.58-0.95$ & $1: 0 \cdot 83-1 \cdot 00$ & $1: 0.87-0.96$ \\
\hline Pharynx (mm) & $0.12 \times 0.13$ & $\begin{array}{r}0.09-0.20 \times \\
0.08-0.22\end{array}$ & $\begin{array}{r}0.09-0.14 \times \\
0.08-0.13\end{array}$ & $\begin{array}{r}0 \cdot 16-0 \cdot 18 \times \\
0 \cdot 18-0 \cdot 20\end{array}$ \\
\hline Oesophagus (mm) & - & $0.05-0.45$ & $0.13-0.37$ & $0.33-0.42$ \\
\hline Cirrus-sac (mm) & - & $\begin{array}{r}0.41-0.75 \times \\
0.03-0.08\end{array}$ & $\begin{array}{r}0.23-0.56 \times \\
0.03-0.05\end{array}$ & $\begin{array}{c}0.55-0.59 \times \\
0.07\end{array}$ \\
\hline Testes (mm) & - & $\begin{array}{r}0.27-0.73 \times \\
0.13-0.46\end{array}$ & $\begin{array}{r}0.12-0.55 \times \\
0 \cdot 10-0.34\end{array}$ & $\begin{array}{r}0.61-0.72 \times \\
0.32-0.50\end{array}$ \\
\hline Testes lobation & [c. 3] & $2-9$ [av. 5.44] & 4-9 [av. 5.93] & $6-8$ [av. 6.75] \\
\hline Ovary (mm) & - & $\begin{array}{c}0 \cdot 10-0.31 \times \\
0 \cdot 07-0.40\end{array}$ & $\begin{array}{c}0.07-0.18 \times \\
0.07-0.22\end{array}$ & $\begin{array}{c}0.26-0.28 \times \\
0.23-0.24\end{array}$ \\
\hline $\begin{array}{l}\text { Body-length : } \\
\text { ovary ratio }\end{array}$ & {$[1: 0 \cdot 07]$} & $1: 0.04-0.07$ & $1: 0.04-0.07$ & $1: 0.06-0.07$ \\
\hline $\begin{array}{l}\text { Vitelline follicles } \\
\text { poral } \\
\text { aporal } \\
\text { Eggs }(\mu \mathrm{m})\end{array}$ & $\begin{array}{l}{[10]} \\
{[8]} \\
43 \times 21\end{array}$ & $\begin{array}{l}9-12 \text { [av. 11·5] } \\
9 \\
35-43 \times 18-20\end{array}$ & $\begin{array}{l}8-12 \text { [av. 10·3] } \\
8-10 \text { [av. 8.67] } \\
37-42 \times 17-20\end{array}$ & $\begin{array}{l}12 \\
9 \\
35-42 \times 15-21\end{array}$ \\
\hline
\end{tabular}

*Square brackets-measurements taken from published figure.

DESCRIPTION (Figs 11, 13, 14, 15). This description is based on many specimens, the measurements, meristic features and numbers of specimens are given in Table 9. The worms are flattened, with a fusiform to broadly pyriform outline (Figs 11, 15A,B). Much of the surface of the worm has irregularly spaced peg-like or scale-like spines. At the posterior end they are embedded in the tegument. The oral sucker is subglobular with a terminal opening. A minute prepharynx leads to a large, subglobular pharynx and a distinct oesophagus. The intestinal bifurcation is in about the middle of the forebody. The caeca, which may be narrow or wide, reach just posterior to the ovary. In larger specimens they may terminate at the level of the testes, but generally they terminate just anteriorly to the testes, usually in the vitelline field or, occasionally, median to it. The circular ventral sucker protrudes slightly from the surface of the worm and is normally slightly larger than the oral sucker.

The excretory pore lies just dorso-subterminally, just anterior to a slight notch in the middle of the posterior margin of the worm. The vesicle is an elongate sac, reaching forward for about a quarter of the length of the hindbody. It is fed by a complex system of small convoluted tubules.

The large testes lie laterally, subsymmetrically in the anterior half of the hindbody. They are distinctly lobate. The vasa efferentia pass from the anterior part of the median edge of the testes and pass diagonally forward, apparently uniting just posteriorly to the cirrus-sac to form a short 
vas deferens, which in turn passes through the posterior extremity of the cirrus-sac, swelling there to form a bipartite seminal vesicle, whose posterior part is much the larger. This posterior moiety is an elongate sac, the anterior part is an oval chamber. The pars prostatica is long, with a narrow lumen, and changes imperceptibly to form a fairly weakly muscular ejaculatory duct. The cirrus$s a c$ is narrow and elongate-oval, having parallel sides for much of its length (Fig. 15C). It has a distinct, if not thick, muscular wall. It may reach, or just overlap the ventral sucker, but, as the worm elongates, the forebody apparently lengthens more rapidly than the cirrus-sac and in the larger worms the cirrus-sac terminates well within the forebody (Fig. 15A). Its posterior end lies quite near to the dorsal surface, but the sac loops ventrally to the left caecum before opening into a small genital atrium, which opens sublaterally on the dorsal surface of the sinistral side of the mid-forebody, through a small eminence.

The small, subglobular ovary (Fig. 13) lies just posteriorly to, or just overlapping, the ventral sucker. A short oviduct passes posteriorly, receives the ducts from the canalicular seminal receptacle and Laurer's canal, more of less together, then receives the common vitelline duct before passing into Mehlis' gland. The seminal receptacle lies just posteriorly to the ovary and may be larger than the ovary, or much smaller. Laurer's canal is short and opens dorsally at about the level of the ovary. The uterus consists of a number of irregularly radiating slings, lying posteriorly to the gonads. There is always a large area of unoccupied parenchyma between the uterus and the body margin (Fig. 14). A single uterine sling, in which the eggs lie in a single file, passes anteriorly between the vitelline fields and enters the genital atrium via a strongly muscular metraterm. The uterus contains not only numerous small operculate eggs but also numerous narrow strands of egg-shell material. It is not clear whether these are egg-filaments or unattached strands. The vitelline duct passes posteriorly from the oviduct, bifurcates, and the two collecting ducts run laterally to a point at about the centre of the cluster of vitelline follicles (Fig. 15D). These follicles lie in two lateral fields between the testes and the ovary and are fairly uniformly subglobular and constant in number (Table 9).

Discussion. This is a distinct species, and the only controversy surrounding its taxonomy is its relationship to the Lepidophyllum from zoarcids in the north Atlantic which we have described as L. appyi. Odhner's original description is of a fairly young lanceolate worm, but subsequent authors (e.g. Miller, 1941; Brinkmann, 1975) have had no difficulty in recognizing their wide spatulate forms as being conspecific and representing different developmental phases.

\section{Lepidophyllum appyi sp. nov.}

Lepidophyllum steenstrupi Odhner, 1902 of Bray (1979) in part and probably Stafford $(1904,1907)$ in part, Linkletter et al. (1977) in part and Cooper (1915).

TYPE-HOST AND LOCALITY. Lycodes vahli, Grand Banks, Newfoundland.

\section{RECORDS}

(i) Material studied

(a) From the NE Atlantic

Lycodes esmarkii [urinary bladder] off NW Scotland. BM(NH) Paratype 1983.3.16.1.

(b) From elsewhere

Lycodes reticulatus [urinary bladder] Grand Banks, Newfoundland. Material of Bray (1979: 419; as $L$. steenstrupi). BM(NH) Paratypes 1977.2.15.140-155.

- - ] Scotian Shelf $\left(44^{\circ} \mathrm{N}, 63^{\circ} \mathrm{W}\right.$; and $42^{\circ} \mathrm{N}, 66^{\circ} \mathrm{W}$; July, 1975$)$. Collector: R. Appy. BM(NH) Paratypes 1983.3.16.2-4.

- [-] Gulf of St Lawrence $\left(62^{\circ} \mathrm{N}, 49^{\circ} \mathrm{W}\right.$; Sept., 1975). Collector: R. Appy. BM(NH) Paratypes 1983.3.16.5-6.

Lycodes vahli [urinary bladder] Sable Island Bank, Nova Scotia. Material of Bray (1979: 419; as L. steenstrupi) BM(NH) Paratypes 1977.2.15.157-185.

[- ] Grand Banks, Newfoundland. Material of Bray (1979: 419; as L. steenstrupi). BM(NH) Holotype 1977.2.15.156. Paratypes 1977.2.15.157-185. 
- [ ] Funk Island Bank, Newfoundland. Material of Bray (1979: 419; as L. steenstrupi). BM(NH) Paratypes 1977.2.15.157-185.

- [- Gulf of St Lawrence. $\left(48^{\circ} \mathrm{N}, 63^{\circ} \mathrm{W}\right.$; May, 1975). Collector: R. Appy. BM(NH) Paratypes 1983.3.16.7-10.

Macrozoarces americanus [urinary bladder] Passamaquoddy Bay, New Brunswick (May, June, 1975; May, Nov., 1976). Collector: R. Appy. BM(NH) Paratypes 1983.3.16.11-19, also material lent by R. Appy; and (Aug., 1982). BM(NH) Paratypes 1983.3.16.20.

- [- ] Gulf of St Lawrence $\left(48^{\circ} \mathrm{N}, 65^{\circ} \mathrm{W}\right.$; May, $1975 ; 48^{\circ} \mathrm{N}, 64^{\circ} \mathrm{W}$, Sept., 1975). Collector: R. Appy. BM(NH) Paratypes 1983.3.16.21-25 also material lent by R. Appy.

- [ - ] Scotian Shelf $\left(45^{\circ} \mathrm{N}, 66^{\circ} \mathrm{W}\right.$; July, 1975). Collector: R. Appy. BM(NH) Paratypes 1983.3.16.26.

(ii) NE Atlantic records from the literature

None.

ASPECTS OF BIOLOGY. The four species of fish recorded as hosts are all members of the family Zoarcidae and the distribution covers the north-west and north-east Atlantic. As with $L$. steenstrupi, nothing is known of the life-cycle, transmission or route of invasion of this worm.

PreVIOUS DESCRIPTIONS. None.

DESCRIPTION (Figs 12, 13, 14, 16). This description is based on many specimens, the numbers of which are included with the measurements on Table 10 . The worms are flattened, with a fusiform to spatulate outline (Figs 12,16), and bear prominent tegumental spines, reaching well into the hindbody. The subglobular oral sucker opens subterminally to terminally and leads via a short prepharynx to a large, subglobular pharynx and a distinct oesophagus which bifurcates in about the middle of the forebody giving rise to caeca which reach into the hindbody and terminate in the vitelline field. The ventral sucker lies in the anterior half of the body and is generally distinctly smaller than the oral sucker.

The excretory pore is dorsally subterminal and leads to a short, narrow vesicle which reaches to the uterus.
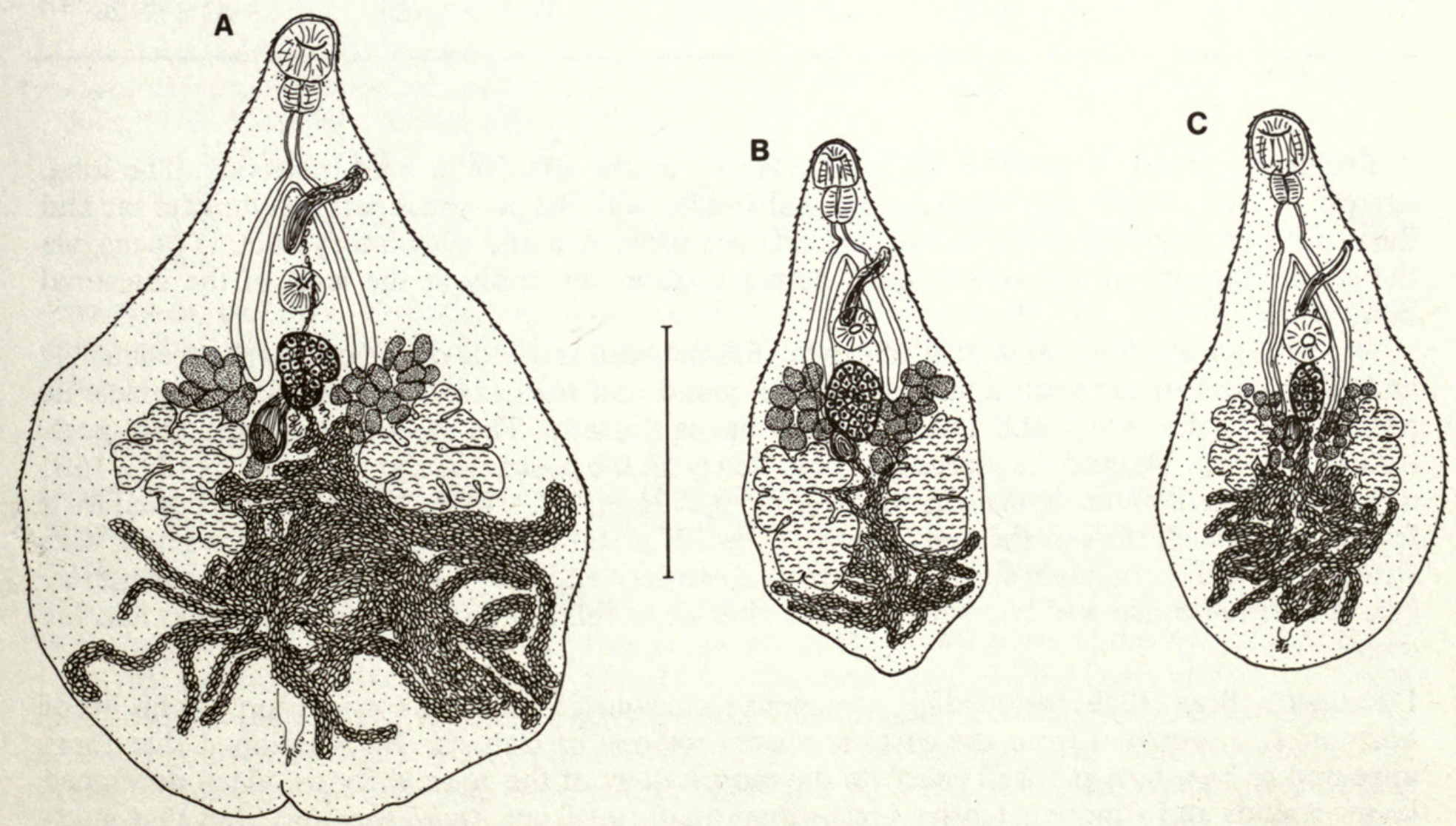

Fig. 16 Lepidophyllum appyi sp. nov. (A), (B) Ventral views, ex Lycodes vahli; (C) Ventral view, ex Macrozoarces americanus. Scale bar: $1 \mathrm{~mm}$. 
Table 10 Measurements of Lepidophyllum appyi

\begin{tabular}{|c|c|c|c|c|}
\hline Host & $\begin{array}{l}\text { Lycodes } \\
\text { vahli }\end{array}$ & $\begin{array}{l}\text { Lycodes } \\
\text { reticulatus }\end{array}$ & $\begin{array}{l}\text { Lycodes } \\
\text { esmarkii }\end{array}$ & $\begin{array}{l}\text { Macrozoarces } \\
\text { americanus }\end{array}$ \\
\hline Number studied & 25 & 18 & 1 & 77 \\
\hline Length (mm) & $1 \cdot 45-3.54$ & $2 \cdot 17-4 \cdot 60$ & $1 \cdot 75$ & $1 \cdot 80-4 \cdot 18$ \\
\hline Breadth (mm) & $0.65-2.35$ & $1 \cdot 57-2 \cdot 30$ & 0.9 & $0.95-2.85$ \\
\hline $\begin{array}{l}\text { Length : forebody } \\
\text { ratio }\end{array}$ & $1: 0 \cdot 29-0 \cdot 41$ & $1: 0 \cdot 32-0 \cdot 38$ & $1: 0.24$ & $1: 0.33-0 \cdot 40$ \\
\hline Oral sucker (mm) & $\begin{array}{r}0.13-0.26 \times \\
0.13-0.27\end{array}$ & $\begin{array}{r}0 \cdot 18-0 \cdot 24 \times \\
0 \cdot 18-0 \cdot 22\end{array}$ & $0.22 \times 0.25$ & $\begin{array}{r}0.20-0.39 \times \\
0.21-0.41\end{array}$ \\
\hline $\begin{array}{l}\text { Ventral sucker } \\
(\mathrm{mm})\end{array}$ & $\begin{array}{r}0.12-0.22 \times \\
0.11-0.22\end{array}$ & $\begin{array}{r}0.15-0.22 \times \\
0.15-0.21\end{array}$ & $0.21 \times 0.23$ & $\begin{array}{r}0.18-0.29 \times \\
0.17-0.31\end{array}$ \\
\hline Sucker-ratio & $1: 0.78-0.95$ & $1: 0.83-1.05$ & $1: 0.92$ & $1: 0.67-0.86$ \\
\hline Pharynx (mm) & $\begin{array}{r}0 \cdot 10-0 \cdot 17 \times \\
0.09-0 \cdot 19\end{array}$ & $\begin{array}{r}0 \cdot 10-0 \cdot 17 \times \\
0 \cdot 12-0.18\end{array}$ & $0.13 \times 0.12$ & $\begin{array}{r}0.12-0.22 \times \\
0.13-0.21\end{array}$ \\
\hline Oesophagus (mm) & $0 \cdot 12-0.32$ & $0 \cdot 15-0.30$ & 0.05 (at least) & $0 \cdot 16-0.35$ \\
\hline Cirrus-sac (mm) & $\begin{array}{r}0.20-0.45 \times \\
0.03-0.09\end{array}$ & $\begin{array}{r}0.30-0.63 \times \\
0.04-0.10\end{array}$ & $0.37 \times 0.06$ & $\begin{array}{r}0.33-0.90 \times \\
0.06-0.13\end{array}$ \\
\hline Testes (mm) & $\begin{array}{r}0.16-0.66 \times \\
0.19-0.57\end{array}$ & $\begin{array}{r}0.35-0.63 \times \\
0.32-0.65\end{array}$ & $\begin{array}{r}0.40-0.56 \times \\
0.25-0.42\end{array}$ & $\begin{array}{r}0.36-0.73 \times \\
0.20-0.70\end{array}$ \\
\hline Testes lobation & 5-14 (av. 7.85) & 5-11 (av. 7·3) & $5-6$ & $7-10$ (av. 7·6) \\
\hline Ovary (mm) & $\begin{array}{r}0 \cdot 11-0 \cdot 40 \times \\
0 \cdot 11-0.29\end{array}$ & $\begin{array}{r}0.17-0.47 \times \\
0.18-0.25\end{array}$ & $0.28 \times 0.22$ & $\begin{array}{r}0.18-0 \cdot 34 \times \\
0 \cdot 14-0.31\end{array}$ \\
\hline $\begin{array}{l}\text { Body-length: } \\
\text { ovary ratio }\end{array}$ & $1: 0 \cdot 06-0 \cdot 14$ & $1: 0 \cdot 07-0 \cdot 14$ & $1: 0 \cdot 16$ & $1: 0.05-0 \cdot 14$ \\
\hline Vitelline follicles & & & & \\
\hline $\begin{array}{l}\text { poral } \\
\text { aporal }\end{array}$ & $\begin{array}{l}10-18 \text { (av. 11.95) } \\
8-14(\text { av. } 9 \cdot 2)\end{array}$ & $\begin{array}{l}13-14(\text { av. } 13 \cdot 5) \\
10-12(\text { av. } 10 \cdot 5)\end{array}$ & $\begin{array}{l}10 \\
9\end{array}$ & $\begin{array}{l}10-12(\text { av. } 10 \cdot 87) \\
7-10(\text { av. } 8 \cdot 12)\end{array}$ \\
\hline Eggs $(\mu \mathrm{m})$ & $35-41 \times 16-22$ & $38-45 \times 19-25$ & $39-44 \times 18-26$ & $33-43 \times 17-26$ \\
\hline
\end{tabular}

The deeply lobed, large testes lie symmetrically in the anterior to mid-hindbody. The long, narrow cirrus-sac contains a bipartite seminal vesicle, with the proximal part an elongate sac and the distal part a smaller globular sac, a short pars prostatica and ejaculatory duct. It opens, via the genital atrium, on the submarginal dorsal surface, sinistrally at the level of the intestinal bifurcation.

The large ovary (Fig. 13) is oval to lobate, lies between the ends of the caeca, pre-testicularly and often close to the ventral sucker. Mehlis' gland and the canalicular seminal receptacle lie posteriorly to the ovary, and Laurer's canal opens dorsally. The uterine coils lie mainly posttesticularly (Fig. 14), and the uterus may completely fill the post-testicular region (Figs 12c,i, 16B) or have an area of parenchyma surrounding it (Figs 12g,m, 16C). In the latter case, it is usual for a few slings to reach close to the body margin (Figs 12f,j, 16A). The numerous eggs are small, with strongly tanned, operculate shells and narrow strands of egg-shell-like material lie in the uterus. The vitellarium consists of two subsymmetrical fields of follicles lying between the testes and the ovary.

Discussion. Bray (1979) included his specimens from zoarcid teleosts (Lycodes spp.) in his list of hosts of $L$. steenstrupi from the eastern coastal regions of Canada. He mentioned that there appeared to be a host-induced effect on the morphology of the zoarcid forms which developed larger gonads and a more extensive uterus than the forms from Anarhichas spp., but that intermediate forms were present. Subsequent studies (see Bray \& Rollinson, 1985) have shown the dangers in postulating host-induced variation without proof, so that it was felt that the features 
listed above in the key and discussion were sufficient to distinguish this form from $L$. steenstrupi at the specific level. Other records of $L$. steenstrupi from zoarcids, i.e. those of Stafford $(1904,1907)$, Cooper (1915) and Linkletter et al. (1977), are all from Macrozoarces americanus from the Canadian east coast and, therefore, probably represent the same form as the one we have studied. The species is named for Dr R. G. Appy of the University of Guelph, Ontario, Canada.

\section{Genus PANOPULA Overstreet \& Pritchard, 1977}

DIAGNOSTIC FEATURES. Body fusiform. Body surface spinous throughout. Oral sucker globular to infundibuliform. Oesophagus distinct. Caeca short, reaching to testes or just overlapping ventral sucker. Ventral sucker subequal or larger than oral sucker. Testes symmetrical, level with ventral sucker or in posterior hindbody. Cirrus-sac large, claviform. Seminal vesicle bipartite or coiled. Pars prostatica wide, vesicular. Ejaculatory duct muscular, long. Genital atrium simple, distinct. Genital pore sinistral, in mid-forebody, lateral or sublateral. Ovary globular to oval, smooth to irregular, post-testicular. Eggs tanned. Uterus post-testicular. Vitellarium two lateral fields of follicles in mid to posterior forebody. Excretory vesicle saccular. In intestine of deep-sea teleosts.

\section{Key to Panopula spp. found in north-east Atlantic}

1 Testes almost entirely in forebody. Sucker ratio $1:>1 \cdot 5$. Caeca overlapping testes

P. bridgeri sp. nov (p. 171)

Testes lateral to ventral sucker. Sucker ratio $1:<1 \cdot 25$. Caeca not reaching testes .

P. spinosa (Zubchenko, 1978) (p. 173)

Panopula bridgeri sp. nov.

TyPe-HOST AND LOCALITY. Polyacanthonotus rissoanus, off Tory Island, NW of Ireland $\left(55^{\circ} \mathrm{N}\right.$, $\left.10^{\circ} \mathrm{W}\right)$.

\section{RECORDS}

Material studied from NE Atlantic

Polyacanthonotus rissoanus [upper intestine] off Tory Island, NW of Ireland $\left(55^{\circ} \mathrm{N}, 10^{\circ} \mathrm{W}\right.$; depth $800-1000 \mathrm{~m}$; June, 1974). BM(NH) holotype 1982.12.8.1. paratypes 1982.12.8.2-5.

- [ - ] St Kilda, W of Scotland $\left(57^{\circ} \mathrm{N}, 09^{\circ} \mathrm{W}\right.$; depth $980-1030 \mathrm{~m}$; June, 1974). BM(NH) paratypes 1982.12.8.6-7.

- [- East Rockall, W of Scotland $\left(57^{\circ} \mathrm{N}, 13^{\circ} \mathrm{W}\right.$; depth $1000-1020 \mathrm{~m}$; June, 1974). BM(NH) paratypes 1982.12.8.8.

AsPECTS OF BIOLOGY. Virtually nothing is known of the biology of this parasite of deep-sea notacanthid eels. The above records indicate its known range. The related species $P$. spinosa (see below) occurs in a closely related eel.

PREVIOUS DESCRIPTIONS. None.

DESCRIPTION (Fig. 17). Fifteen specimens (one as sections) were studied. The measurements are given in Table 11. The mature worms are fusiform (Fig. 17A,B), bearing scale-like spines which reach just into the hindbody. The oval oral sucker opens subterminally with a somewhat slit-like opening and leads into a short prepharynx which is not always apparent in whole-mounts. A small, oval pharynx leads to a long, narrow oesophagus, which bifurcates at about the level of the genital pore, just anteriorly to the middle of the forebody. The caeca are short, but fairly narrow and reach back to about the level of the anterior margin of the ventral sucker and almost to the posterior edge of the testes, where they terminate blindly. The transversely elongate-oval ventral sucker lies in about the centre of the body and is larger than the oral sucker. It is rather weakly developed and is reduced to the form of a weakly-muscled pad rather than a sucker.

The excretory pore is terminal and leads into the vesicle which is in the form of a flattened sac reaching almost to the seminal receptacle. 

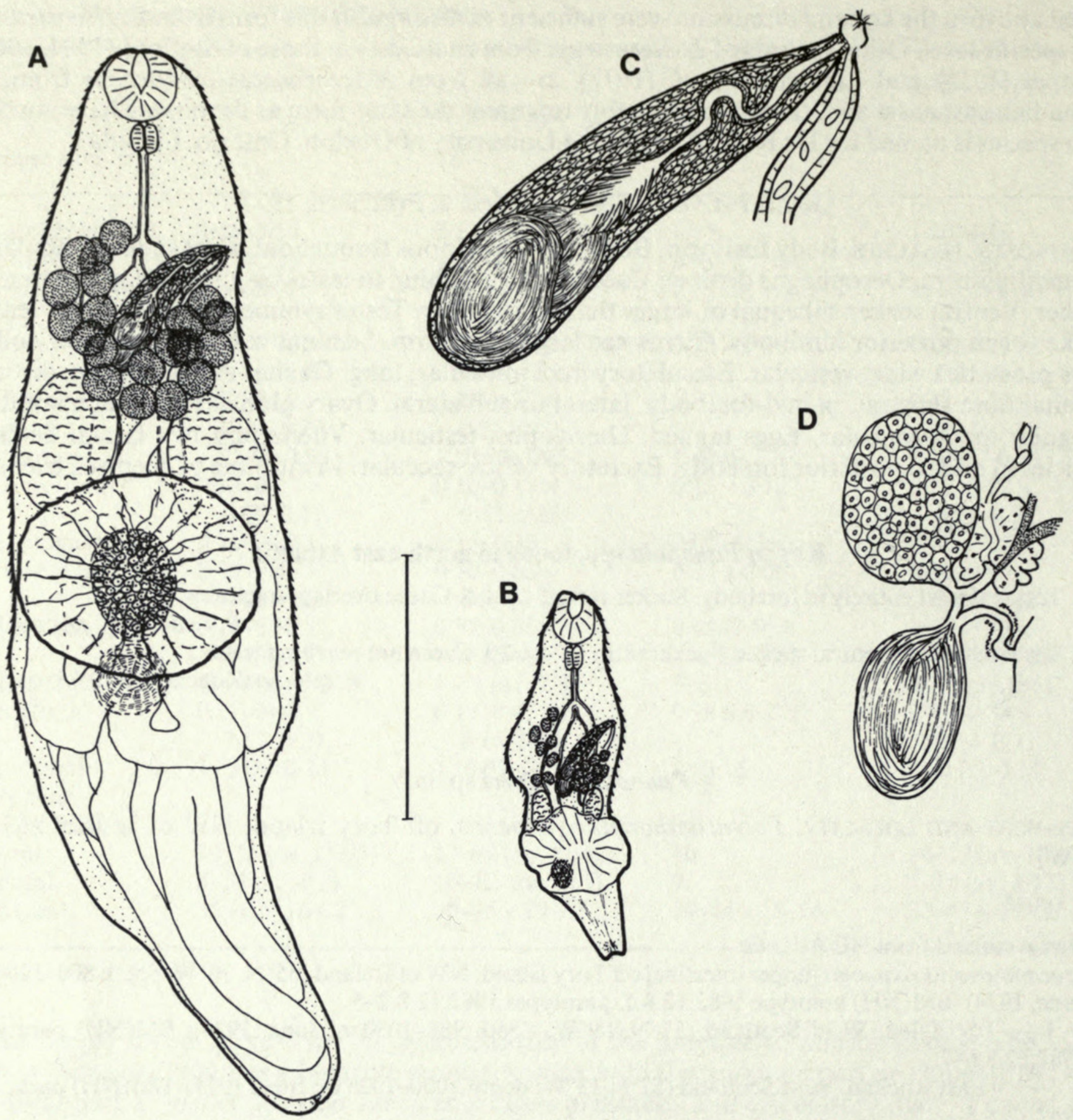

Fig. 17 Panopula bridgeri sp. nov. (A) Ventral view, mature worm; (B) Ventral view, immature worm; (C) Terminal genitalia; (D) Proximal female genitalia. Scale bar: A, B 0.5 mm.

The testes are smoothly or slightly irregularly oval, and lie extracaecally and subsymmetrically in the posterior forebody. The worm is clearly protandrous. The cirrus-sac is claviform and reaches posteriorly to about the anterior edge of the testes. It contains a seminal vesicle composed of two oval parts, a vesicular pars prostatica and a narrow, long, coiled or sinuous ejaculatory duct, which is sometimes extended to form a cirrus (Fig. 17C). It opens into a small, simple genital atrium which opens on the sinistrally submarginal ventral surface, just anterior to the middle of the forebody.

The oval ovary lies post-testicularly and dorsally to the ventral sucker. The oviduct passes posteriorly from the ovary and receives the duct from the canalicular seminal receptacle and Laurer's canal, and the common vitelline duct, before entering Mehlis' gland which lies sinistrally to the ovary. The large seminal receptacle lies posteriorly to the ovary and Laurer's canal arises from it. Laurer's canal is short, muscular and sinuous, opening dorsally at the level just posterior to the ovary (Fig. 17D). The uterus takes up nearly the whole of the post-testicular region of the worm (in the hindbody and dorsally to the ventral sucker) and contains numerous eggs with tanned, 
Table 11 Measurements of Panopula spp.

\begin{tabular}{|c|c|c|c|c|}
\hline \multirow{3}{*}{$\begin{array}{l}\text { Authority } \\
\text { Locality }\end{array}$} & \multirow{3}{*}{$\begin{array}{l}\text { P. bridgeri } \\
\text { Present study } \\
\text { see text }\end{array}$} & \multicolumn{3}{|c|}{$P$. spinosa } \\
\hline & & \multirow{2}{*}{$\begin{array}{l}\text { Zubchenko (1978) } \\
2 \text { localities }\end{array}$} & \multicolumn{2}{|c|}{ Present study } \\
\hline & & & SW Iceland & NW Atlantic \\
\hline Length (mm) & $0.67-2.01$ & $3 \cdot 2-4 \cdot 2$ & $3 \cdot 5$ & $2 \cdot 9$ \\
\hline Breadth (mm) & $0 \cdot 22-0.55$ & $1 \cdot 1-1 \cdot 5$ & $1 \cdot 15$ & $1 \cdot 4$ \\
\hline $\begin{array}{l}\text { Length : forebody } \\
\text { ratio }\end{array}$ & $1: 0.39-0.56$ & - & $1: 0 \cdot 53$ & $1: 0 \cdot 54$ \\
\hline Oral sucker (mm) & $\begin{array}{r}0.09-0.20 \times \\
0.09-0.19\end{array}$ & $0.45-0.48$ & $0.40 \times 0.47$ & $0.41 \times 0.44$ \\
\hline $\begin{array}{l}\text { Ventral sucker } \\
(\mathrm{mm})\end{array}$ & $\begin{array}{r}0.16-0.35 \times \\
0.16-0.43\end{array}$ & $\begin{array}{r}0.47-0.53 \times \\
0.44-0.56\end{array}$ & $0.46 \times 0.45$ & $0.46 \times 0.50$ \\
\hline Sucker-ratio & $1: 1 \cdot 5-2 \cdot 8$ & - & $1: 0.96$ & $1: 1 \cdot 14$ \\
\hline Prepharynx (mm) & very short & $0.03-0.04$ & 0.02 & 0.06 \\
\hline Pharynx (mm) & $\begin{array}{r}0.04-0.07 \times \\
0.04-0.07\end{array}$ & $\begin{array}{r}0 \cdot 21-0 \cdot 27 \times \\
0 \cdot 19-0 \cdot 21\end{array}$ & $0.21 \times 0.22$ & $0.21 \times 0.19$ \\
\hline Oesophagus (mm) & $0.09-0.74$ & $0.55-0.75$ & $0 \cdot 75$ & $? 0.2$ curved \\
\hline Cirrus-sac (mm) & $\begin{array}{r}0.18-0.35 \times \\
0.05-0.13\end{array}$ & - & $1.0 \times 0.22$ & $1.2 \times 0.31$ \\
\hline Testes (mm) & $\begin{array}{r}0.07-0.28 \times \\
0.04-0.19\end{array}$ & $\begin{array}{r}0.43-0.59 \times \\
0.25-0.40\end{array}$ & $0.45-0.30$ & $\begin{array}{r}0.50-0.55 \times \\
0.31-0.33\end{array}$ \\
\hline Ovary (mm) & $\begin{array}{l}0.06-0.20 \\
0.08-0.17\end{array}$ & $\begin{array}{r}0.25-0.35 \times \\
0.25-0.32\end{array}$ & $0.26 \times 0.24$ & $0.31 \times 0.30$ \\
\hline $\begin{array}{l}\text { Vitelline follicles } \\
\quad \text { poral } \\
\text { aporal } \\
\text { Eggs }(\mu \mathrm{m})\end{array}$ & $\begin{array}{l}10-12 \\
9-10 \\
36-40 \times 15-17\end{array}$ & $\begin{array}{l}9-10 \\
33-38 \times 13-17\end{array}$ & $\begin{array}{l}12 \\
9 \\
33-36 \times 15-17\end{array}$ & $\begin{array}{l}12 \\
10 \\
33-36 \times 16-17\end{array}$ \\
\hline
\end{tabular}

operculate shells. A muscular metraterm enters the genital atrium beside the cirrus-sac. The vitellarium consists of two lateral bunches of subglobular follicles which almost meet in the median line posteriorly. The aporal field reaches from the intestinal bifurcation and overlaps the anterior edge of the testis posteriorly, but the poral field does not reach as far anteriorly, always being confined to the region postero-lateral to the cirrus-sac.

Discussion. This species clearly belongs in Panopula, as the testes lie in the forebody. The features which distinguish it from $P$. spinosa are mentioned in the key. As far as the type of the genus, $P$. cavernossa Overstreet \& Pritchard, 1977, is concerned, the present species and $P$. spinosa can be distinguished by having the poral field of the vitellarium entirely posterior to the cirrus-sac and in having a bipartite, as opposed to a coiled, tubular, seminal vesicle. The species is named for $\mathrm{Mr}$ J. P. Bridger of the MAFF Laboratory, Lowestoft, Suffolk, England.

Panopula spinosa (Zubchenko, 1978) n. comb.

Antorchis spinosus Zubchenko, 1978.

TYPE-HOST AND LOCALITY. Notacanthus chemnitzii [=nasus], Rejkjanes Ridge, SW Iceland.

\section{RECORDS}

(i) Material studied

(a) From the NE Atlantic

Notacanthus chemnitzii [intestine] off SW Iceland (March, 1973). Donated by A. V. Gaevskaya. BM(NH) 1981.12.3.7. 
(b) From elsewhere

Notacanthus chemnitzii [intestine] NW Atlantic (Nov., 1974). Donated by A. V. Gaevskaya. BM(NH) 1981.12.3.6.

(ii) NE Atlantic records from the literature

Notacanthus chemnitzii [intestine] northern part of Rejkjanes Ridge, off SW Iceland. Zubchenko (1978: 117 as Antorchis spinosus).

ASPECTS OF BIOLOGY. One host species only is recorded. Our specimens bear the information quoted for them and Zubchenko's (1978) locality information is more detailed. His record from the north-west Atlantic is from off Labrador.

PREVIOUS DESCRIPTIONS. Zubchenko (1978: 117).

DESCRIPTION (Fig. 18). Based on two flattened whole-mounts. The dimensions are included on Table 11. These elongate pyriform worms have an extensive forebody. The surface bears large spines which reach to the posterior extremity, becoming slightly more widely spaced posteriorly. The oral sucker is almost terminal, infundibuliform and leads through a short but distinct prepharynx to an oval pharynx. The oesophagus is long, either straight or curved depending on the extension of the forebody. It bifurcates in about the mid-forebody giving off short, saccular caeca which just reach to the vitelline fields. The rounded ventral sucker is slightly smaller to slightly larger than the oral sucker.

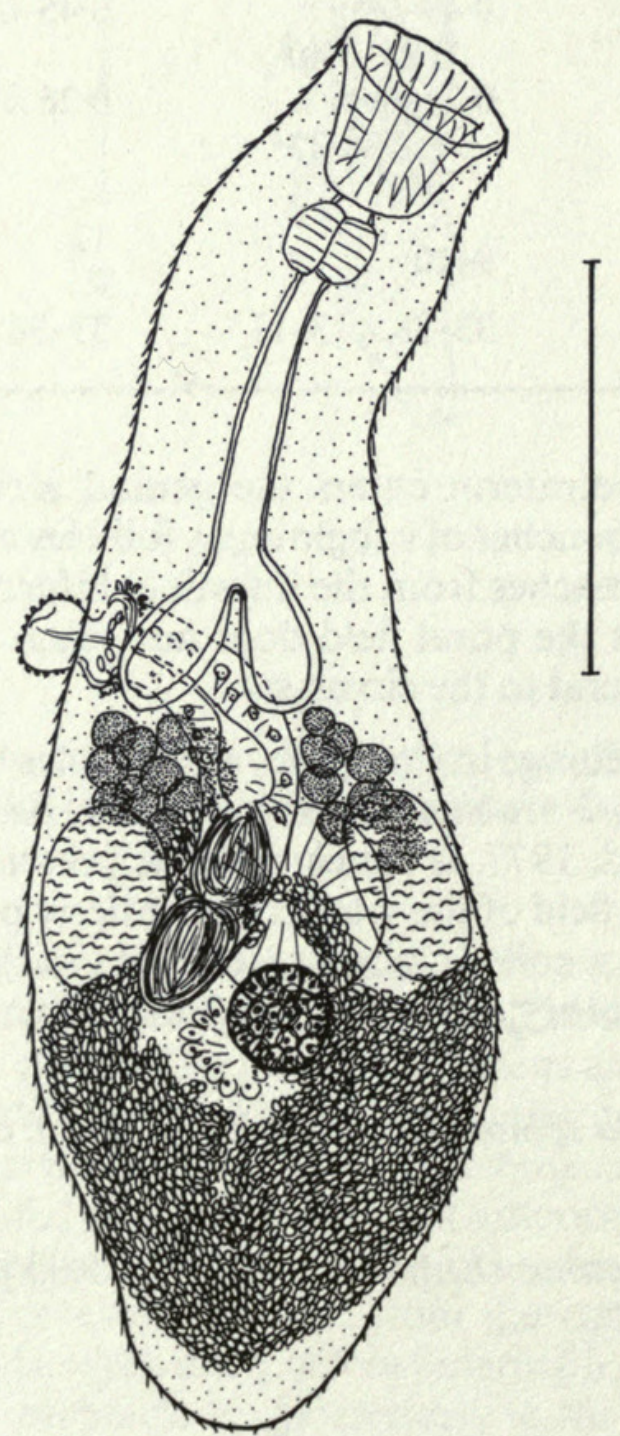

Fig. 18 Panopula spinosa (Zubchenko), dorsal view, flattened specimen from SW of Iceland. Scale bar: $1 \mathrm{~mm}$. 
The excretory pore is terminal and the excretory system is not clearly seen, but in the region posterior to the uterus, appears to be a broad sac.

The elongate oval testes lie laterally to antero-laterally to the ventral sucker in a more or less symmetrical arrangement. The large, curved cirrus-sac overlaps the ventral sucker to about the middle to the posterior edge. It contains a large seminal vesicle made up of two broadly oval parts, a wide, vesicular pars prostatica and a long, muscular ejaculatory duct which may form a large cirrus bearing numerous small bosses. The genital atrium is large, with muscular walls, and opens at or near the left lateral margin of the mid-forebody.

The round ovary lies submedially, post-testicularly and overlaps the posterior edge of the ventral sucker. Almost immediately posterior to it lies a small seminal receptacle, with a prominent Mehlis' gland to the left of the ovary. Laurer's canal was not visible on these flattened worms. The uterus fills most of the post-testicular and post-ovarian space and contains numerous thick-shelled, operculate eggs. The strongly muscular metraterm opens into the base of the genital atrium. The vitellarium consists of two small lateral fields of follicles lying immediately anterior to the testes on either side.

Discussion. We believe that this species is clearly a zoogonid, not a fellodistomid as suggested by Zubchenko (1978). Although in some ways similar to Antorchis spp., the sublateral genital pore, large tegumental spines and apparently undivided excretory vesicle clearly associate it with the zoogonids, and the location of the testes and vitellarium, the structure of the intestine and the host suggest affinities with the genus Panopula.

\section{Genus BRACHYENTERON Manter, 1934}

Cypseluritrematoides Yamaguti, 1970.

Prolateroporus Yamaguti, 1971.

DiAGNOSTIC FEATURES. Body fusiform to pyriform. Body surface spinous. Oral sucker globular or infundibuliform. Oesophagus distinct. Caeca terminating in forebody or at level of ventral sucker. Ventral sucker in mid-body or just anterior; larger than or subequal to oral sucker, may have tegumental pit on posterior lip. Testes symmetrical or subsymmetrical, close to or overlapping ventral sucker. Cirrus-sac claviform to elongate claviform. Seminal vesicle bipartite or coiled. Pars prostatica vesicular, oval to elongate. Cirrus long, may be extruded. Genital pore marginal to submarginal, sinistral in forebody. Ovary overlapping ventral sucker or in forebody, pre- or post-testicular. Uterus fills most of hindbody. Metraterm well developed. Vitellarium lateral fields of follicles in forebody or at level of ventral sucker. Excretory vesicle elongate saccular. In gallbladder or intestine of marine teleosts.

\section{Key to Brachyenteron spp. found in the north-east Atlantic}

1 Sucker ratio $1: 2$. Genital pore at level of pharynx. Tegumental pit on posterior lip of ventral sucker. Oral sucker subglobular . . . . . . . . . . B. pycnorganum (Rees, 1953) (p. 175)

Sucker ratio $1: 1$. Genital pore at level of intestinal bifurcation. No tegumental pit seen. Oral sucker infundibuliform .

B. campbelli sp. nov. (p. 179)

\section{Brachyenteron pycnorganum (Rees, 1953) Overstreet \& Pritchard, 1977}

Steganoderma pycnorganum Rees, 1953.

Deretrema pycnorganum (Rees, 1953) Yamaguti, 1953.

Steganoderma spinosa Polyansky, 1955.

Pseudochetosoma spinosa (Polyansky, 1955) Yamaguti, 1971.

Brachyenteron spinosum (Polyansky, 1955) Overstreet \& Pritchard, 1977.

Yamagutia anarhichae Brinkmann, 1956.

Prolateroporus anarhichae (Brinkmann, 1956) Yamaguti, 1971. 
TYPE-HOST AND LOCALITY. Anarhichas minor, Iceland.

\section{RECORDS}

(i) Material studied

(a) From the NE Atlantic

Anarhichas denticulatus [gall-bladder, bile-duct] Iceland-Faeroes Channel $\left(64^{\circ} \mathrm{N}, 10^{\circ} \mathrm{W}\right.$; depth $592-620 \mathrm{~m}$; June, 1974). BM(NH) 1982.12.9.18-40.

Anarhichas lupus [bile-duct] northern North Sea. $\left(61^{\circ} \mathrm{N}, 02^{\circ} \mathrm{E}\right.$; depth $159 \mathrm{~m}$; May, 1985). BM(NH) 1985.7.3.16.

Anarhichas minor [bile-duct] east coast of Iceland $\left(66^{\circ} \mathrm{N}, 13^{\circ} \mathrm{W}\right.$; depth $119 \mathrm{~m}$.) Material of G. Rees (possibly type, but not labelled as such). (See Rees, 1953:21). BM(NH) 1976.4.9.16.

- [gall-bladder] Neskaupstadur, Iceland. Material lent by Museum of Natural History, Rejkjavik. Type-specimen of Yamagutia anarhichae. (See Brinkmann, 1956: 17; Bray \& Gibson, 1980: 202).

- - ] Anton Dohrn Bank (65 N, 30 W; depth 370-440 m; May, 1974). BM(NH) 1982.12.9.4-13.

[gall-bladder, bile-duct] Iceland-Faeroes Channel $\left(63^{\circ} \mathrm{N}, 11^{\circ} \mathrm{W}\right.$; depth $410-420 \mathrm{~m}$; June, 1974). $\mathrm{BM}(\mathrm{NH})$ 1982.12.9.14-17.

(b) From elsewhere

Anarhichas lupus [gall-bladder] off Nova Scotia. (See Bray, 1979: 418; as Deretrema p.). BM(NH) 1977.2.15.103-110.

Anarhichas minor [gall-bladder] off Newfoundland. (See Bray, 1979: 418; as Deretrema p.). BM(NH) 1977.2.15.111.

(ii) NE Atlantic records from the literature

Anarhichas minor [bile-duct] east coast of Iceland. Rees (1953: 21; Brinkmann (1956) erroneously quotes this record as from $A$. lupus).

— [gall-bladder] Neskaupstadur and Húsavík, Iceland. Brinkmann (1956: 16; as $S$. pycnorganum: 17; as Yamagutia anarhichae).

ASPECTS OF BIOLOGY. Nothing is known of the life-cycle of this worm, but it is worth noting that metacercariae allocated to the related species B. doederleiniae Yamaguti, 1938 have been found in deep water and red shrimps by Reimer (1984). B. pycnorganum is found almost exclusively in the gall-bladder and bile-duct of Anarhichas spp. in the north Atlantic Ocean. Polyansky recorded nine specimens in the intestine in 1 of 15 specimens of $A$. lupus in the Barents Sea. It appears to occupy the niches occupied by Fellodistomum fellis (Olsson, 1868) and possibly Steringophorus agnotus (Nicoll, 1909) in A. lupus (see Bray \& Gibson, 1980) but is sometimes found sympatrically with $F$. fellis in A. minor (see Brinkmann, 1956, 1975; Bray, 1979).

Previous DeSCRIPTIONS. Rees (1953: 21); Brinkmann (1956: 16, 17); Polyansky (1955: 58).

DESCRIPTION (Figs 19, 20). Five worms, three in serial section were studied. Their dimensions are included in Table 12. They are somewhat fusiform, with the forebody being asymmetrical due to the genital pore being carried on a slight eminence (Fig. 19A). The surface normally bears small spines embedded in the tegument over almost the entire surface, often with only the tips showing through. A distinct tegumental pit lies on the median line close to the posterior border of the opening of the oral sucker. It is seen clearly only on SEM preparations (Fig. 20). The globular oral sucker opens subterminally, and leads via a short prepharynx and a small subglobular pharynx into a distinct oesophagus, lined with tegument, which bifurcates in the posterior forebody. The short, wide, divergent caeca reach to about the middle of the ventral sucker. Most of each caecum is lined with epithelium, with tegumental lining occurring only anteriorly. The large, circular ventral sucker, normally about twice the width of the oral sucker, lies in the middle of the worm.

The excretory pore lies terminally and leads to a narrow, I-shaped undivided vesicle reaching to the level of the seminal receptacle.

Large, oval testes lie more or less symmetrically in the anterior hindbody. The cirrus-sac is large, usually recurved sharply (in unflattened material) and has a strongly muscular wall. It reaches posteriorly to a level between about the middle of the ventral sucker to well within the hindbody (Fig. 19A,B). Proximally, the cirrus-sac contains a large, bipartite seminal vesicle; the two broadly oval parts have muscular walls which may be lined with a single layer of anuclear blebs. The vesicular pars prostatica is lined with filaments which project into the lumen and are embedded in 


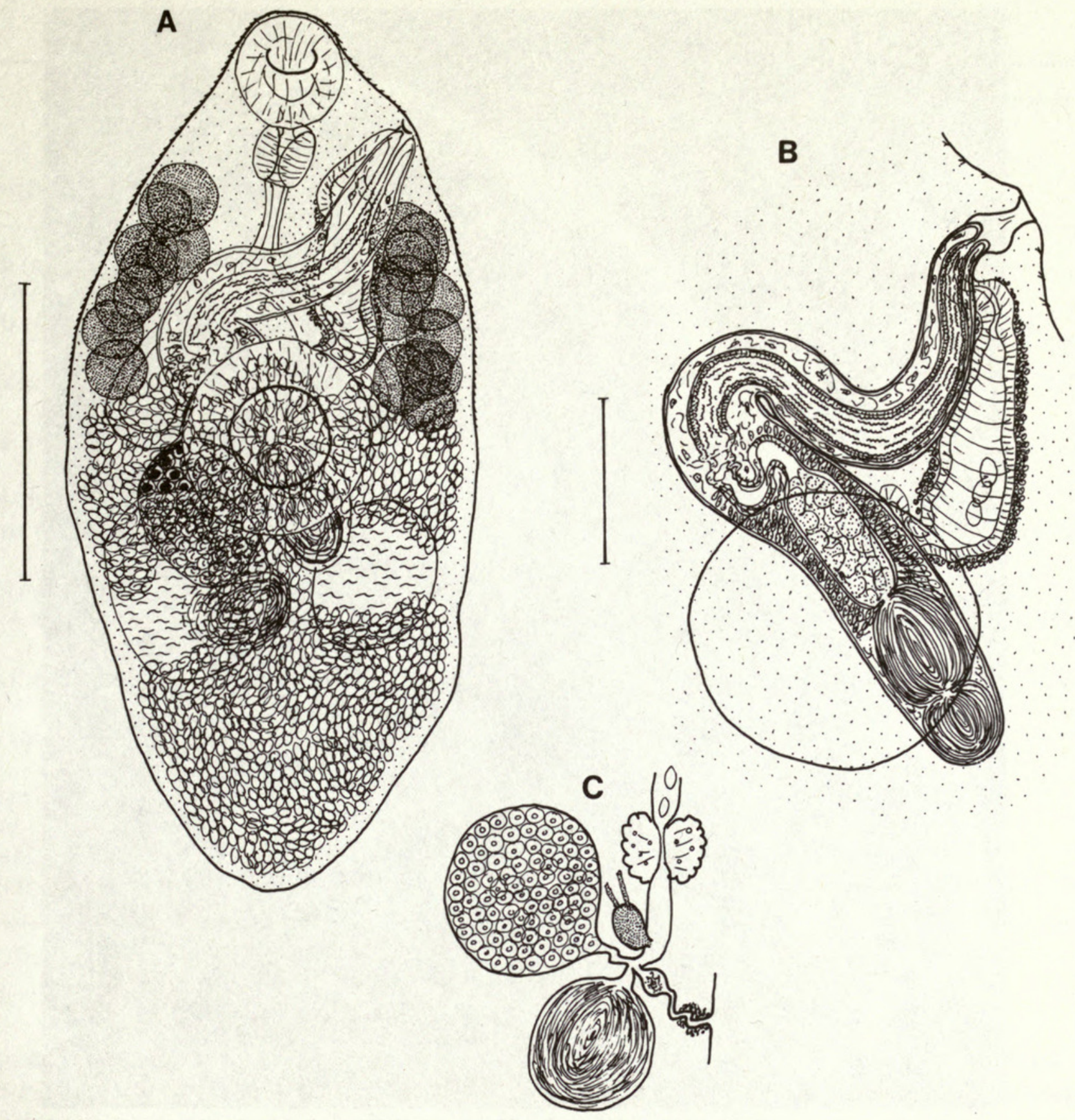

Fig. 19 Brachyenteron pycnorganum (Rees). (A) Ventral view, ex Anarhichas minor; (B) Terminal genitalia; (C) Proximal female genitalia. Scale bars: A 0.5 mm, B $0.2 \mathrm{~mm}$.

the granular matrix. Prior to the point where the cirrus-sac curves sharply, the ejaculatory duct has its origin. It is distinguishable from the pars prostatica by its initially narrower lumen and thicker muscular wall. Its inner surface is covered with muscular tubercles. The pars prostatica and the proximal part of the ejaculatory duct are surrounded by a layer of gland-cells. At about the point of recurvature the gland-cell layer more or less disappears, leaving a narrow layer of connective tissue, containing an occasional gland-cell, between the thick muscular ejaculatory duct and the thinner, but still strongly muscular, wall of the cirrus-sac. The ejaculatory duct may be extruded to form a cirrus, which is usually short (see fig. 23c of Polyansky, 1955) and covered with tubercles. When the worm is flattened (see Rees, 1953, fig. 2) the cirrus may be almost completely extended and the relative positions and shape of some of the contents of the cirrus-sac may be substantially altered, as may the shape of the cirrus-sac itself. The withdrawn cirrus opens into the base of a distinct, narrow, genital atrium which opens on a slight eminence on the left margin of the forebody at the level of the pharynx.

The oval ovary lies on, or to the right of, the median line, overlapping the posterior margin of the ventral sucker and is either pre-testicular or overlaps the testes. The narrow oviduct passes from 


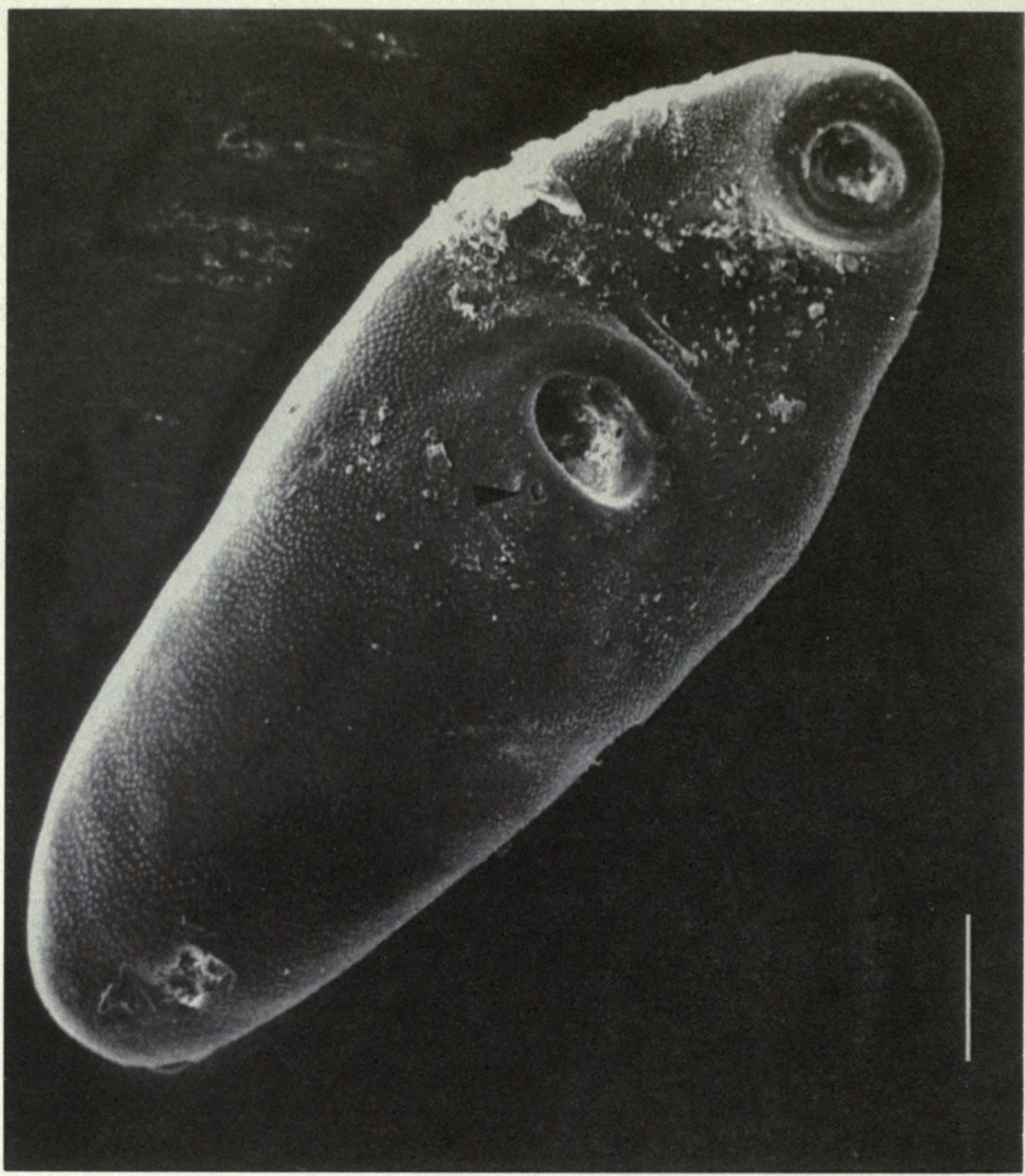

Fig. 20 Brachyenteron pycnorganum (Rees). SEM micrograph showing tegumental pit (arrowed). Scale bar: $0 \cdot 2 \mathrm{~mm}$.

the left dorsal side of the ovary, receiving the ducts of the canalicular seminal receptacle and the vitelline system before passing into a small Mehlis' gland lying sinistrally to the ovary. The seminal receptacle lies more or less directly posterior to the ovary and may be nearly as large. Laurer's canal passes dorsally from the seminal receptacle arising close to its junction with the oviduct (Fig. 19C). Initially it is dilate and contains a small amount of apparently spent spermatozoa and vitelline material. Distally it is narrow, convoluted and ensheathed in a narrow layer of gland-cells. It opens dorsally at about the level of the seminal receptacle. The uterus, on leaving Mehlis' gland anteriorly, curves posteriorly and coils throughout most of the hindbody, both anteriorly and posteriorly to the testes. It contains numerous operculate, tanned eggs with numerous fine filaments. The metraterm is long, strongly muscular and surrounded by a layer of gland cells. It commences dorsally to the ventral sucker and runs a convoluted course to enter the genital atrium dorsally to the cirrus-sac. The common vitelline duct widens to form a reservoir almost immediately on leaving the oviduct. Two narrow ducts pass from the reservoir towards the vitellarium, which consists of two subsymmetrical lateral fields of globular follicles in the forebody, but posterior to the cirrus-sac on the poral side. The fields reach from a level just posterior to the cirrus-sac to about the middle of the ovary. 
Table 12 Measurements of Brachyenteron spp.

\begin{tabular}{|c|c|c|c|c|c|}
\hline \multirow[b]{2}{*}{ Authority } & \multicolumn{4}{|c|}{ B. pycnorganum } & \multirow{2}{*}{$\begin{array}{l}\text { B. campbelli } \\
\text { Present } \\
\text { study }\end{array}$} \\
\hline & $\begin{array}{l}\text { Rees } \\
(1953)\end{array}$ & $\begin{array}{l}\text { Polyansky } \\
\text { (1955) }\end{array}$ & $\begin{array}{l}\text { Brinkmann } \\
\text { (1956) }\end{array}$ & $\begin{array}{l}\text { Present } \\
\text { study }\end{array}$ & \\
\hline Length (mm) & $2 \cdot 44-2 \cdot 82$ & $1 \cdot 87-1 \cdot 2$ & $1 \cdot 04$ & $0 \cdot 94-2 \cdot 1$ & $2 \cdot 1$ \\
\hline Breadth $(\mathrm{mm})$ & $1 \cdot 41-1 \cdot 52$ & $0 \cdot 87-1 \cdot 2$ & 0.49 & $0.37-0.98$ & 0.43 \\
\hline $\begin{array}{l}\text { Length : forebody } \\
\text { ratio }\end{array}$ & - & - & - & $1: 0.32-0.44$ & $1: 0 \cdot 36$ \\
\hline Oral sucker $(\mathrm{mm})$ & $0.36 \times 0.34$ & $0 \cdot 29-0 \cdot 37$ & $0 \cdot 13$ diam. & $\begin{array}{r}0.14-0.28 \times \\
0.12-0.29\end{array}$ & $0.22 \times 0.17$ \\
\hline $\begin{array}{l}\text { Ventral sucker } \\
(\mathrm{mm})\end{array}$ & 0.62 diam. & $0 \cdot 42-0 \cdot 50$ & 0.32 diam. & $\begin{array}{r}0.24-0.55 \times \\
0.24-0.58\end{array}$ & $0.11 \times 0.17$ \\
\hline Sucker-ratio & $1: 1 \cdot 85$ & {$[1: 1 \cdot 2-1 \cdot 3]^{*}$} & $1: 2 \cdot 45$ & $1: 1 \cdot 6-2 \cdot 0$ & $1: 1$ \\
\hline Pharynx (mm) & $0 \cdot 14$ diam. & $\begin{array}{c}0 \cdot 11-0 \cdot 14 \\
\text { diam. }\end{array}$ & 0.06 diam. & $\begin{array}{r}0.05-0 \cdot 16 \times \\
0.06-0.16\end{array}$ & $0.11 \times 0.08$ \\
\hline Oesophagus (mm) & $0 \cdot 20$ & $0 \cdot 12$ & - & $0.06-0.23$ & c. 0.09 \\
\hline Cirrus-sac (mm) & $0.98 \times 0.26$ & $\begin{array}{c}1 \cdot 04-1 \cdot 37 \\
\text { long }\end{array}$ & 0.55 long & $\begin{array}{r}0.48-1 \cdot 52 \times \\
0 \cdot 10-0 \cdot 20\end{array}$ & $0.51 \times 0.09$ \\
\hline Testes (mm) & $\begin{array}{r}0.27-0.38 \times \\
0.23-0.33\end{array}$ & $\begin{array}{r}0 \cdot 19-0.25 \times \\
0.30-0.40\end{array}$ & - & $\begin{array}{r}0.12-0.42 \times \\
0.09-0.36\end{array}$ & $\begin{array}{c}0.19-0.22 \times \\
0.13\end{array}$ \\
\hline Ovary (mm) & $0 \cdot 25$ diam & $\begin{array}{l}0 \cdot 17-0 \cdot 25 \\
\text { diam. }\end{array}$ & - & $\begin{array}{r}0.08-0.32 \times \\
0.06-0.22\end{array}$ & $0.20 \times 0.12$ \\
\hline $\begin{array}{l}\text { Vitelline follicles } \\
\text { poral } \\
\text { aporal }\end{array}$ & $\begin{array}{l}10-12 \\
8-11\end{array}$ & $9-12$ & - & $\begin{array}{l}11-14 \\
8-13\end{array}$ & $\begin{array}{l}10 \\
9\end{array}$ \\
\hline Eggs $(\mu \mathrm{m})$ & $31-38 \times 19-20$ & $29-34 \times 16-21$ & $40 \times 25$ & $34-40 \times 18-24$ & $32-33 \times 14-17$ \\
\hline
\end{tabular}

*Taken from published figure.

Discussion. Brinkmann (1956) was the first to consider Steganoderma spinosa a synonym of $S$. pycnorganum. Overstreet \& Pritchard (1977), however, pointed out that $S$. spinosa apparently differs from $S$. pycnorganum in lacking a 'well-developed metraterm-complex'. We believe that, despite this fact, and the finding of S. spinos $a$ in the intestine of $A$. lupus, the overall morphology is so similar that it is apparent that we are dealing with a single sub-arctic form. Zubchenko (1980) recorded $S$. spinosa from A. minor in the north-west Atlantic, and our specimens from this host and region are clearly $B$. pycnorganum.

As mentioned by Bray \& Gibson (1980) we have examined the single specimen of Yamagutia anarhichae Brinkmann, 1956, and consider it a teratological specimen of Brachyenteron pycnorganum.

\section{Brachyenteron campbelli sp. nov.}

TYPE-HOST AND LOCALITY. Polyacanthonotus rissoanus, $58^{\circ} \mathrm{N}, 10^{\circ} \mathrm{W}$.

\section{RECORDS}

(i) Material studied from the NE Atlantic region

Polyacanthonotus rissoanus [intestine] NW off Scotland $\left(58^{\circ} \mathrm{N}, 10^{\circ} \mathrm{W}\right.$; depth $1300-1320 \mathrm{~m}$; Oct., 1978). $\mathrm{BM}(\mathrm{NH})$ holotype 1981.2.18.1.

(ii) NE Atlantic records from the literature

None.

PREVIOUS DESCRIPTIONS. None. 

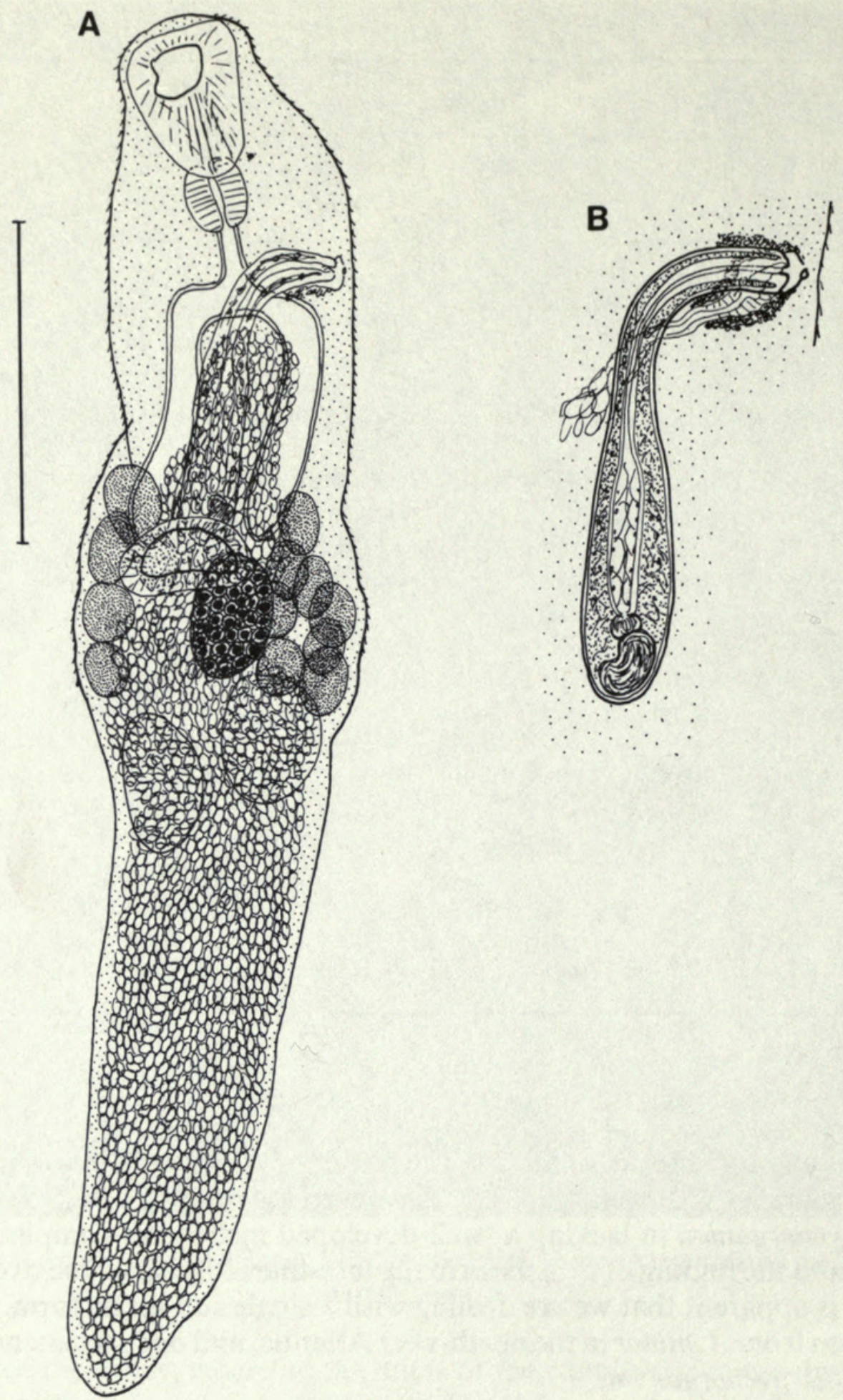

Fig. 21 Brachyenteron campbelli sp. nov. (A) Ventral view; (B) Terminal genitalia. Scale bar: 0.5 mm.

DESCRIPTION (Fig. 21). Only a single worm was recovered and its measurements are given on Table 12. It has been examined in whole-mount preparation and as serial sections. Certain details, particularly of the proximal female system, were not clearly seen. The worm is elongate (Fig. 21A), and the surface bears spines to the level of the anterior part of the hindbody. It is widest at the level of the ventral sucker and vitellarium, and the contours of the lateral margins of this region reflect the outlines of the underlying vitelline follicles. The infundibuliform oral sucker leads via a short prepharynx to an oval pharynx and a distinct oesophagus which divides in about the middle of the forebody. The caeca are narrow and fairly short, terminating at the level of the ventral sucker, which is relatively weakly developed and lies in the anterior half of the body.

The excretory pore is dorsally subterminal and leads to a narrow vesicle which reaches to the gonads. 
The testes are oval and lie slightly obliquely in the anterior hindbody, with the anterior testis on the poral side of the body, close to the ovary. The cirrus-sac is a long, narrow, claviform organ curved at a right-angle at its anterior end (Fig. 21B). It contains a small, bipartite seminal vesicle, made up of a larger slightly elongate proximal part and a small globular distal part. A long, vesicular pars prostatica reaches to about half-way to the point of curvature and leads to a long, muscular ejaculatory duct. The genital atrium is small, but distinct, muscular and surrounded by gland-cells, as are the distal regions of the cirrus-sac and particularly the metraterm. The pore opens ventrally close to the sinistral margin at the level of the oesophagus.

The oval ovary lies more or less on the median line, overlapping the posterior edge of the ventral sucker. The seminal receptacle is smaller than the ovary and overlaps it postero-dorsally. Laurer's canal was not clearly seen, but apparently opens dorsally at the level of the testes. The uterus, distended with operculate eggs, fills most of the hindbody and also lies in the median region of the forebody, between the caeca. The post-testicular eggs are relatively weakly tanned compared with those in the pre-testicular region. The strongly muscular metraterm enters the genital atrium dorsally to the cirrus-sac and is surrounded by a thick layer of gland-cells. The vitellarium consists of oval follicles in fields lateral to the region around the ventral sucker, but overlapping into both the fore and hindbodies.

Discussion. This is one of the occasions when, despite having but one specimen available, it is practically certain that we are dealing with a new form. It is the only member of the genus to possess an infundibuliform oral sucker and a uterus which reaches anteriorly to the testes and into the forebody. The species is named for Dr R. A. Campbell of Southeastern Massachusetts University, North Dartmouth, Massachusetts, USA.

\section{Genus STEGANODERMATOIDES Parukhin \& Lyadov, 1979}

Hudsonia Campbell, 1975 nec Edwards, 1923. Allosteganoderma Campbell, 1983.

DIAGNOSTIC FEATURES. Body fusiform to elongate fusiform, bearing prominent spines. Oral sucker terminal or subterminal. Prepharynx distinct. Oesophagus long. Caeca reach to testis level. Ventral sucker large, in about middle of body, bearing equatorial row of large, muscular papillae. Testes diagonal in mid to posterior hindbody. Cirrus-sac large, recurved. Seminal vesicle saccular, bipartite or convoluted tubular. Pars prostatica long, convoluted. Ejaculatory duct muscular. Genital atrium large, muscular. Periatrial gland present, undivided. Genital pore sinistral, lateral in mid-posterior forebody. Ovary submedian, pre-testicular. Uterus substantially or totally pretesticular. Metraterm muscular, surrounded by gland-cell sheath. Vitelline follicles in two lateral fields in anterior hindbody. Excretory vesicle reaches to testes or not. In alimentary system of deep-sea teleosts.

COMMENTs. This genus is discussed in detail by Bray (1985a and in press $b)$. One species is found in the north-east Atlantic.

Steganodermatoides maceri sp. nov.

? Hudsonia agassizi from Alepocephalus bairdii of Zubchenko (1984).

TYPE-HOST AND LOCALITY. Alepocephalus bairdii, off Tory Island, W of Ireland.

RECORDS

(i) Material studied from the NE Atlantic region

Alepocephalus bairdii [rectum] off Tory Island, W. of Ireland, $\left(55^{\circ} \mathrm{N}, 10^{\circ} \mathrm{W}\right.$; depth $800-840 \mathrm{~m}$; and $55^{\circ} \mathrm{N}$, $11^{\circ} \mathrm{W}$; depth 800-820 m, April, 1973). BM(NH) Holotype 1984.2.23.1. Paratypes 1984.2.23.2-8.

- - St Kilda, off W. of Scotland. $\left(57^{\circ} \mathrm{N}, 10^{\circ} \mathrm{W}\right.$; depth $650-660 \mathrm{~m}$ and $800-830 \mathrm{~m}$; June, 1974).

$\mathrm{BM}(\mathrm{NH})$ Paratypes 1984.2.23.9-11.

[- ] Porcupine Bank, off W. Ireland. $\left(54^{\circ} \mathrm{N}, 14^{\circ} \mathrm{W}\right.$; depth $1000 \mathrm{~m}$; June, 1974). BM(NH) Paratypes 1984.2.23.12.

[- $]$ South Rockall, off W. Scotland $\left(55^{\circ} \mathrm{N}, 17^{\circ} \mathrm{W}\right.$; depth $821-850 \mathrm{~m}$; June, 1974). BM(NH) Paratype 1984.2.23.13. 
[- $]$ East Rockall, off W. Scotland $\left(57^{\circ} \mathrm{N}, 13^{\circ} \mathrm{W}\right.$; depth 1000-1060 m; June, 1974). BM(NH) Paratypes 1984.2.23.14-20.

- [- $]$ Sulisker, off NW Scotland $\left(60^{\circ} \mathrm{N}, 07^{\circ} \mathrm{W}\right.$; depth $900 \mathrm{~m}$; June, 1974). BM(NH) Paratypes 1984.2.23.21. (59 ${ }^{\circ} \mathrm{N}, 08^{\circ} \mathrm{W}$; depth $1160-1220 \mathrm{~m}$; Oct., 1978). BM(NH) Paratypes 1984.2.23.22-23. 1984.2.23.24.

(ii) NE Atlantic records from the literature

Alepocephalus bairdii [?] North-east Atlantic. Zubchenko (1984: 78, as Hudsonia agassizi-likely to be $S$. maceri).

Aspects of BIOLOGY. This species is clearly both host-specific to A. bairdii and site-specific to the rectum. Nothing is known of the life-history or wider distribution.

PREVIOUS DESCRIPTIONS. None.

DESCRIPTION (Figs 22, 23). Thirty-eight specimens, including one set of serial sections, were studied. The measurements are given on Table 13. The worms are elongate, widest at about the level of the ventral sucker, or in larger worms just posterior to the ventral sucker (Fig. 22A). The forebody is narrow, being constricted just posteriorly to the oral sucker and gradually widening towards the ventral sucker. The hindbody is elongate, wider anteriorly and tapering to a narrow, pointed end. The surface bears large spines, the only parts lacking these spines being a narrow band around the oral sucker (Fig. 23A) and the posterior extremity. The large oral sucker opens subterminally to virtually terminally. It is more or less globular and leads via a distinct prepharynx to an oval pharynx which is often orientated obliquely and apparently distorted (Fig. 22A). A long, sinuous oesophagus reaches just into the posterior half of the forebody where it bifurcates, giving rise to two narrow caeca which diverge and, passing close to the lateral margin of the body, reach to about the level of the anterior margin of the posterior testis. The large ventral sucker lies in about the centre of the body. It tends to have a rather angular shape, rather than being circular, and across its internal equator there lies a row of about five or six large, fungiform papillae (Fig. 23B).

The terminal excretory pore leads into a narrow vesicle which reaches about half-way to the posterior testis in larger worms, lying dorsally to the uterus. In younger worms it may reach to, but not overlap, the testes.

The testes lie close together, diagonally in about the middle of the hindbody. They are oval to pyriform with more or less smooth margins. The cirrus-sac is a large recurved or coiled organ, with strong muscular walls, reaching from a level dorsal to the anterior half of the ventral sucker to the sinistrally placed genital atrium (Fig. 22B). The seminal vesicle is bipartite. The proximal part is saccular or tubular and smaller than the large, oval distal part, to which it is connected by a short, narrow canal. The long, convoluted vesicular pars prostatica is lined with a layer of large, anuclear blebs or globules, and passes through a mass of gland-cells. The male duct forms, distally, a narrow, muscular ejaculatory duct, lined with muscular annuli. It may extend through the genital pore as a wide blunt cirrus or be withdrawn into the proximal part of the cirrus-sac. When the cirrus is extended the genital atrium forms a strongly muscular sucker-like protuberance, and it appears that spermatophores may be formed. The genital atrium in resting condition is large and pocketed with a strong muscular wall lined with long filamentous structures reaching well into the lumen. The so-called periatrial gland surrounds the genital atrium and extends along the metraterm (Fig. 22B). It appears to be delimited by a membranous layer or parenchymatous capsule. The genital pore lies on the sinistral margin just posteriorly to the intestinal bifurcation.

The large, oval ovary lies anteriorly to the testes, usually closer to them than to the ventral sucker and more or less in the median line. The oviduct passes from the ovary close to its posterior end and soon receives both the common duct from Laurer's canal and the canalicular seminal receptacle and the common vitelline duct (Fig. 22C); then it enters Mehlis' gland. The seminal receptacle lies directly posterior to the ovary, lying anteriorly to or overlapping the anterior testis. It may be larger than the ovary when fully distended. Laurer's canal passes from the anterior edge of the seminal receptacle and is a short, convoluted tube opening dorsally at the level of the ovary. The vitelline connecting ducts join close to Mehlis' gland to form a small reservoir which is connected to 

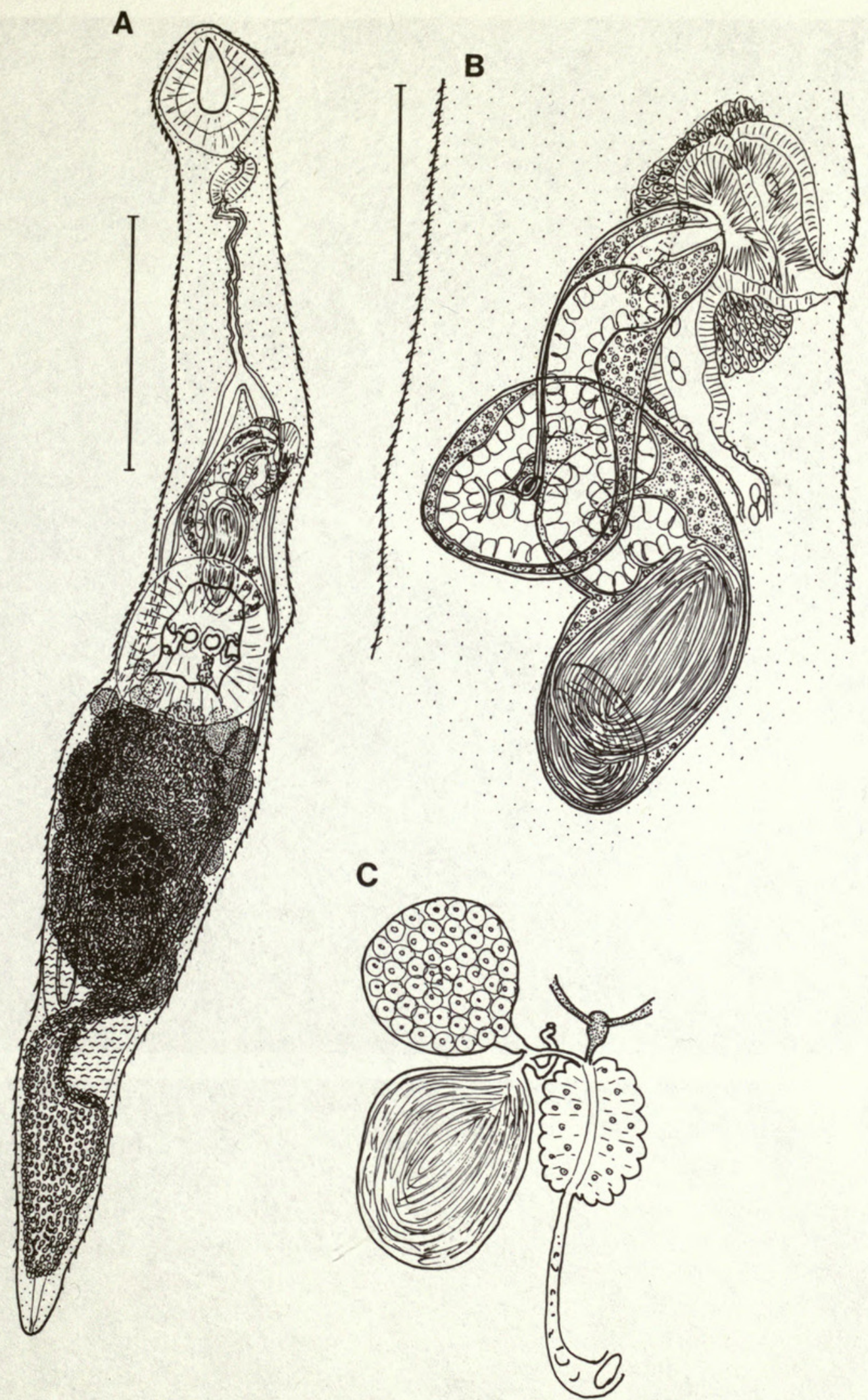

Fig. 22 Steganodermatoides maceri sp. nov. (A) Ventral view; (B) Terminal genitalia; (C) Proximal female genitalia. Scale bars: A $1 \mathrm{~mm}$, B $0.2 \mathrm{~mm}$.

the oviduct by a narrow common duct. The initial sling of the uterus passes posteriorly from Mehlis' gland and contains components of the eggs, but it is not clear where they are assembled so a uterine oötype may be present. The uterus passes into the post-testicular region. All specimens have at least some slings in this region and in larger worms a substantial part of the uterus is post-testicular. Eggs in the post-testicular part of the uterus are weakly tanned, and as the uterus passes the level of the testes going anteriorly, the eggs become fully tanned and may obscure the gonads. The uterus is convoluted between the testes and the ventral sucker and a narrow, 

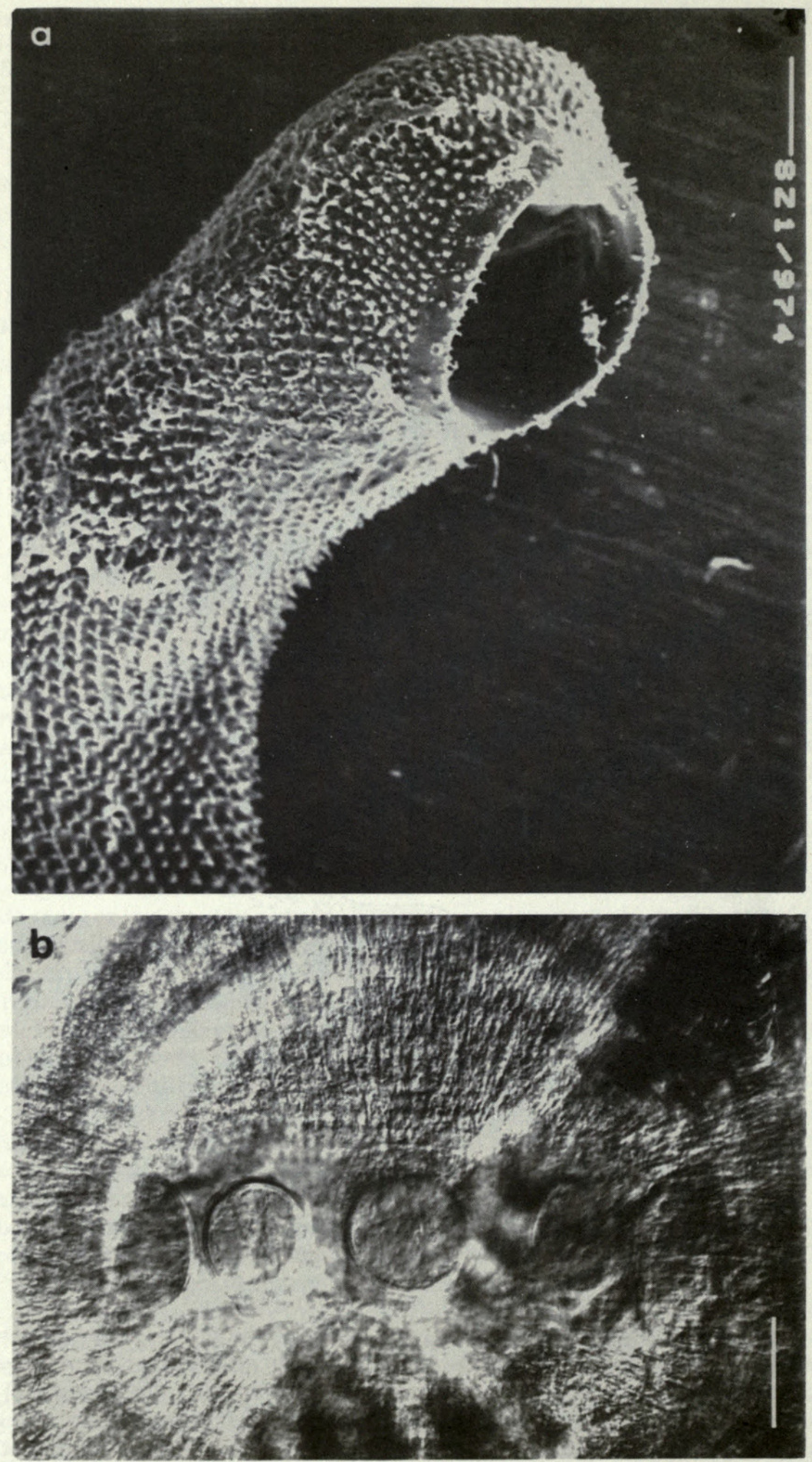

Fig. 23 Steganodermatoides maceri sp. nov. (a) SEM micrograph of the anterior end; (b) Optical photomicrograph showing papillae in ventral sucker. Scale bars: $a, b 0.01 \mathrm{~mm}$. 
Table 13 Measurements of Neosteganoderma glandulosum and Steganodermatoides maceri

\begin{tabular}{|c|c|c|c|c|}
\hline \multirow[b]{2}{*}{ Authority } & \multicolumn{3}{|c|}{ N. glandulosum } & \multirow{2}{*}{$\begin{array}{l}\text { S. maceri } \\
\text { Present } \\
\text { study }\end{array}$} \\
\hline & $\begin{array}{l}\text { Byrd } \\
\text { (1964) }\end{array}$ & $\begin{array}{l}\text { Bray } \\
\text { (1973) }\end{array}$ & $\begin{array}{l}\text { Yamaguti } \\
(1970)\end{array}$ & \\
\hline Length (mm) & $1.80-3.42$ & $1 \cdot 0-1 \cdot 38$ & $2 \cdot 2-2 \cdot 5$ & $3 \cdot 75-6 \cdot 2$ \\
\hline Breadth (mm) & $0.74-1.26$ & $0.76-0.96$ & $0.85-1.7$ & $0 \cdot 55-1 \cdot 1$ \\
\hline $\begin{array}{l}\text { Length : forebody } \\
\text { ratio }\end{array}$ & {$[1: 0 \cdot 49-0 \cdot 51]^{*}$} & $1: 0.26-0.38$ & {$[1: 0 \cdot 47]^{*}$} & $1: 0 \cdot 35-0 \cdot 47$ \\
\hline Oral sucker $(\mathrm{mm})$ & $\begin{array}{c}0 \cdot 19-0 \cdot 23 \\
\text { wide }\end{array}$ & $\begin{array}{r}0.26-0.33 \times \\
0.27-0.38\end{array}$ & $\begin{array}{r}0.20-0.25 \times \\
0.20-0.27\end{array}$ & $\begin{array}{c}0.38-0.60 \\
\text { diam. }\end{array}$ \\
\hline $\begin{array}{l}\text { Ventral sucker } \\
(\mathrm{mm})\end{array}$ & $\begin{array}{l}0 \cdot 24-1 \cdot 22 \\
\text { wide }\end{array}$ & $\begin{array}{r}0.27-0.33 \times \\
0.69-0.77\end{array}$ & $\begin{array}{r}0.25-0.32 \times \\
0.57-0.78\end{array}$ & $\begin{array}{r}0.53-0.65 \times \\
0.48-0.98\end{array}$ \\
\hline Sucker-ratio & $1: 3 \cdot 9-1 \cdot 6$ & $1: 2 \cdot 1-2 \cdot 8$ & {$[1: 3]^{*}$} & $1: 1 \cdot 18-1 \cdot 64$ \\
\hline Prepharynx (mm) & - & - & - & $0.02-0.05$ \\
\hline Pharynx (mm) & $\begin{array}{r}0.06-0.10 \times \\
0.06-0.09\end{array}$ & $\begin{array}{c}0 \cdot 11-0 \cdot 13 \\
\text { diam. }\end{array}$ & $\begin{array}{r}0.08-0.09 \times \\
0.05-0.08\end{array}$ & $\begin{array}{r}0.13-0 \cdot 25 \times \\
0 \cdot 12-0.19\end{array}$ \\
\hline Oesophagus (mm) & $0.50-0.98$ & - & $0 \cdot 15-0.20$ & $0.52-0.90$ \\
\hline Cirrus-sac $(\mathrm{mm})$ & - & $\begin{array}{r}0.94-1.01 \times \\
0.15-0.30\end{array}$ & $\begin{array}{r}0.52-0.60 \times \\
0.12-0.14\end{array}$ & $\begin{array}{r}0.80-1 \cdot 25 \times \\
0 \cdot 17-0.23\end{array}$ \\
\hline Testes (mm) & $\begin{array}{r}0.24-0.47 \times \\
0.25-0.43\end{array}$ & $\begin{array}{r}0.19-0.30 \times \\
0.27-0.40\end{array}$ & $\begin{array}{r}0.25-0.30 \times \\
0 \cdot 15-0.18\end{array}$ & $\begin{array}{r}0.30-0.80 \times \\
0.17-0.50\end{array}$ \\
\hline Ovary (mm) & $\begin{array}{r}0 \cdot 21-0 \cdot 27 \times \\
0 \cdot 19-0 \cdot 25\end{array}$ & $0.27 \times 0.27$ & $0.13 \times 0.12$ & $\begin{array}{r}0.25-0.30 \times \\
0 \cdot 17-0.30\end{array}$ \\
\hline Eggs $(\mu \mathrm{m})$ & $26-31 \times 12-15$ & $26-31 \times 16-21$ & $25-35 \times 16-20$ & $28-33 \times 14-19$ \\
\hline
\end{tabular}

*Taken from published figure.

convoluted sling passes dorsally to the latter. The uterine wall widens about half-way between the ventral sucker and the genital atrium forming a metraterm which is a strongly muscular, wide tube surrounded by a prominent glandular sheath and which opens into the dorsal part of the genital atrium. The vitellarium consists of two lateral fields of about 15 follicles extending between about the posterior margin of the ventral sucker and the ovary.

Discussion. This species differs from the three previously described members of the genus, $S$. kergeleni Parukhin \& Lyadov, 1979, S. allocytti (Tkachuk, 1979) and S. agassizi (Campbell, 1975) by having a conspicuous post-testicular uterine development. This means that the testes are relatively further forward in $S$. maceri and the excretory vesicle does not always reach to the testes, as it does in the other species. The eggs of $S$. maceri $(28-33 \mu \mathrm{m})$ are distinctly smaller than those of $S$. agassizi $(48-55 \mu \mathrm{m})$. The species is named for Dr C. T. Macer of the MAFF Laboratory, Lowestoft, Suffolk, England.

\section{Genus NEOSTEGANODERMA Byrd, 1964}

DiAGNOSTIC FEATURES. Body pyriform, surface spinous. Oral sucker large, globular or infundibuliform. Prepharynx short. Oesophagus distinct. Caeca reach to testes, or almost so. Ventral sucker large, transversely elongate; divided equatorially by dorsal cleft and ventral ridge. Testes symmetrical in anterior hindbody. Cirrus-sac large, muscular. Seminal vesicle convoluted tubular. Pars prostatica long, wide. Ejaculatory duct muscular. Genital atrium large, pocketed. Periatrial gland present, undivided. Genital pore submarginal, sinistral, in posterior forebody. Ovary globular, inter-testicular. Uterus mainly post-testicular. Eggs tanned, opercular. Metraterm muscular. Vitellarium two small lateral fields of follicles, in anterior hindbody, pre-testicular. 
Excretory pore terminal or dorsally subterminal; vesicle an elongate sac. In intestine of deep-sea teleosts.

Comment. One species is found in the north-east Atlantic.

\section{Neosteganoderma glandulosum Byrd, 1964}

Proctophantastes glandulosa (Byrd, 1964) Yamaguti, 1971.

Proctophantastes polymixiae Yamaguti, 1970.

Neosteganoderma polymixiae (Yamaguti, 1970) Bray, 1973.

TYPE-HOST AND LOCALITY. Polymixia lowei, Straits of Florida.

\section{RECORDS}

(i) Material studied

(a) From the NE Atlantic region

Beryx decadactylus [intestine] SW Bay of Biscay $\left(44^{\circ} \mathrm{N}, 07^{\circ} \mathrm{W}\right.$; depth $340-350 \mathrm{~m}$; Jan., 1971). Material of Bray (1973: 170). BM(NH) 1973.5.17.54-56.

(b) From elsewhere

Polymixiajaponica [intestine] Hawaii. Holotype and paratype of Proctophantastes polymixiae. USNM 63568. Polymixia lowei [lower intestine] Straits of Florida. Paratype. USNM 60166.

(ii) NE Atlantic records from the literature

Beryx decadactylus [intestine] SW Bay of Biscay. Bray (1973: 170).

ASPECTS OF BIOLOGY. Nothing is known of the life-history of this species. It occurs in fishes of the genera Polymixia, Beryx, Cyttoidops and Cyttus from Florida, the Bay of Biscay, Hawaii and the Australia-New Zealand region.

Previous desCriptions. Byrd (1964: 105); Bray (1973: 170); Yamaguti (1970: 35).

DESCRIPTION (Figs 24, 25). Ten specimens from B. decadactylus were studied, one in serial section, together with one whole-mount from $P$. lowei and two whole-mounts from $P$. japonica. The dimensions are given on Table 13 . When contracted the worms have a broadly pyriform outline (see Bray, 1973, fig. 8a) but when relaxed thay are more elongate (Fig. 24A). Quincunxially arranged acuminate spines are distributed throughout the surface of the forebody and a few spines are to be found at the posterior extremity. The subterminal oral sucker leads through a small prepharynx and a globular pharynx to a distinct, dorsally-curved, oesophagus which bifurcates close behind the pharynx to form caeca which reach back just dorsally to the testes. The large, muscular, transversely elongate ventral sucker is almost as wide as the body, and in these contracted specimens, lies in the anterior half of the body. It is divided equatorially by a cleft in the dorsal surface of the musculature and a corresponding ridge across the inner, ventral surface (Fig. 25A).

The excretory system was seen only in the sectioned specimen and in this case the pore was subterminally on the dorsal surface, possibly displaced by either the enlargement' of the uterus or the contraction during fixation. Initially narrow, the vesicle widens anteriorly and terminates as a sac ventrally to the seminal receptacle.

The large testes are obscured by eggs in whole-mounts, but apparently lie symmetrically just posterior to the ventral sucker and close to the lateral margins of the worm. The cirrus-sac is very large with well-developed muscular walls. It is strongly recurved with the proximal part curved round dorsally to the distal part, which lies transversely across the worm overlapping the anterior margin of the ventral sucker (Fig. 24B). The proximal part reaches from close to the aporal margin nearly to the median region. The seminal vesicle is in the form of a tightly coiled tube and takes up a relatively small proportion of the cirrus-sac. The main part of the male duct within the cirrus-sac is the pars prostatica, which is lined with numerous, closely packed filamentous projections. The ejaculatory duct is wide with prominent muscular walls, and, at about its middle, a radial layer of hyaline spine-like structures may be seen. It is not clear whether these are, in fact, spines or fragments of longitudinal muscle. The male duct within the cirrus-sac is surrounded by numerous 


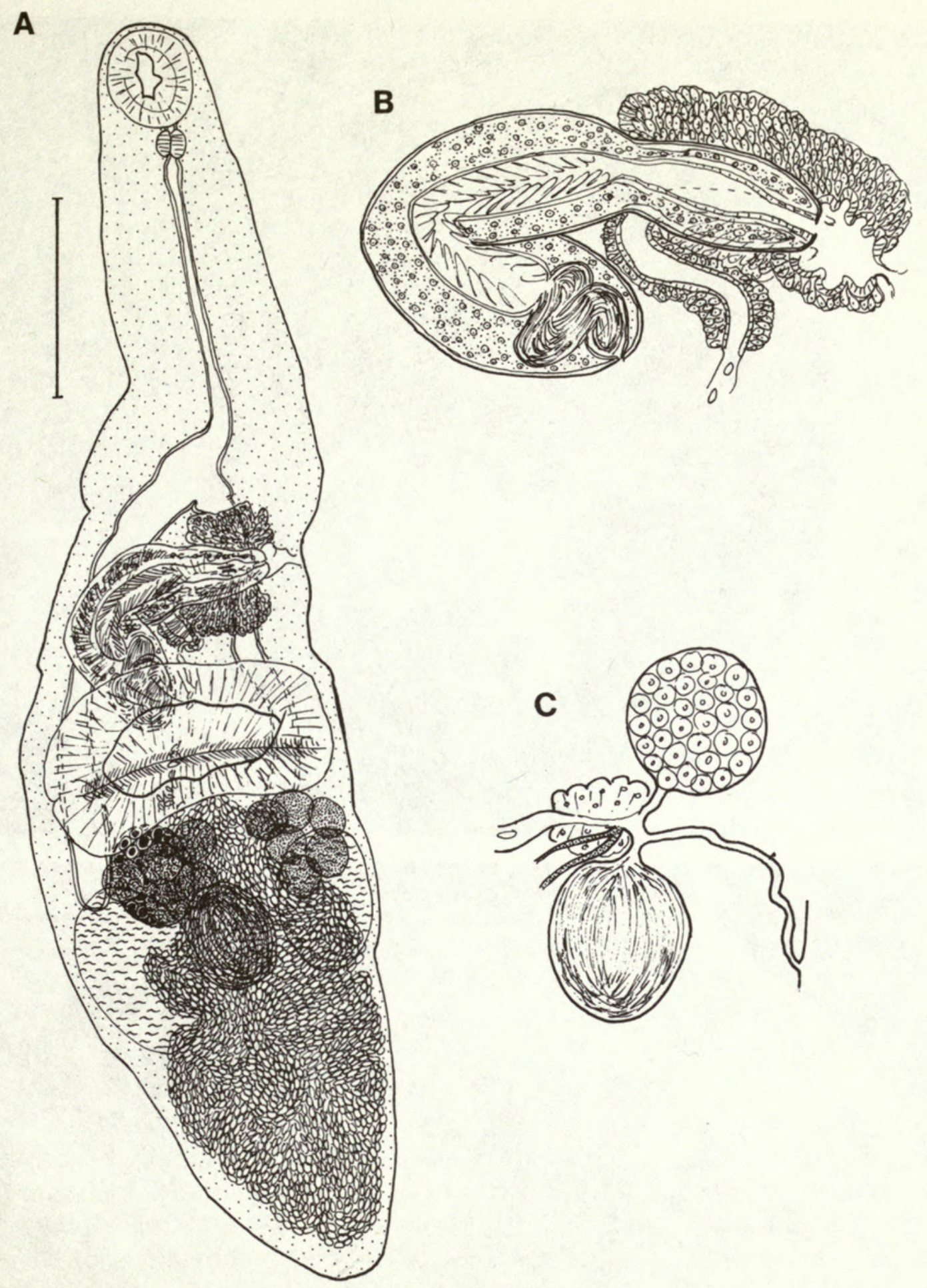

Fig. 24 Neosteganoderma glandulosum Byrd. (A) Ventral view of paratype specimen; (B) Terminal genitalia of specimen ex Beryx decadactylus; (C) Proximal female genitalia of specimen ex $B$. decadactylus. Scale bar: $0.5 \mathrm{~mm}$.

gland-cells. The genital atrium has a thick, muscular wall, thrown into complex pockets and ridges, and opens via a narrow genital pore submarginally, close to the left margin of the posterior forebody. The genital atrium is surrounded by a thick layer of gland-cells which forms a sheath surrounding not only the genital atrium but also the distal end of the cirrus-sac and a considerable length of the metraterm. This glandular mass is distinctly delimited from the parenchyma and apparently forms a discrete organ which has been called a 'periatrial gland' (Yamaguti, 1970) (Fig. 25b).

The subglobular to irregularly quadrilateral ovary lies aporally to the median line between the testes. It gives off from its left margin a muscular oviduct which almost immediately enters a well-developed Mehlis' gland. A narrow duct passes dorsally leading to a large, oval canalicular 

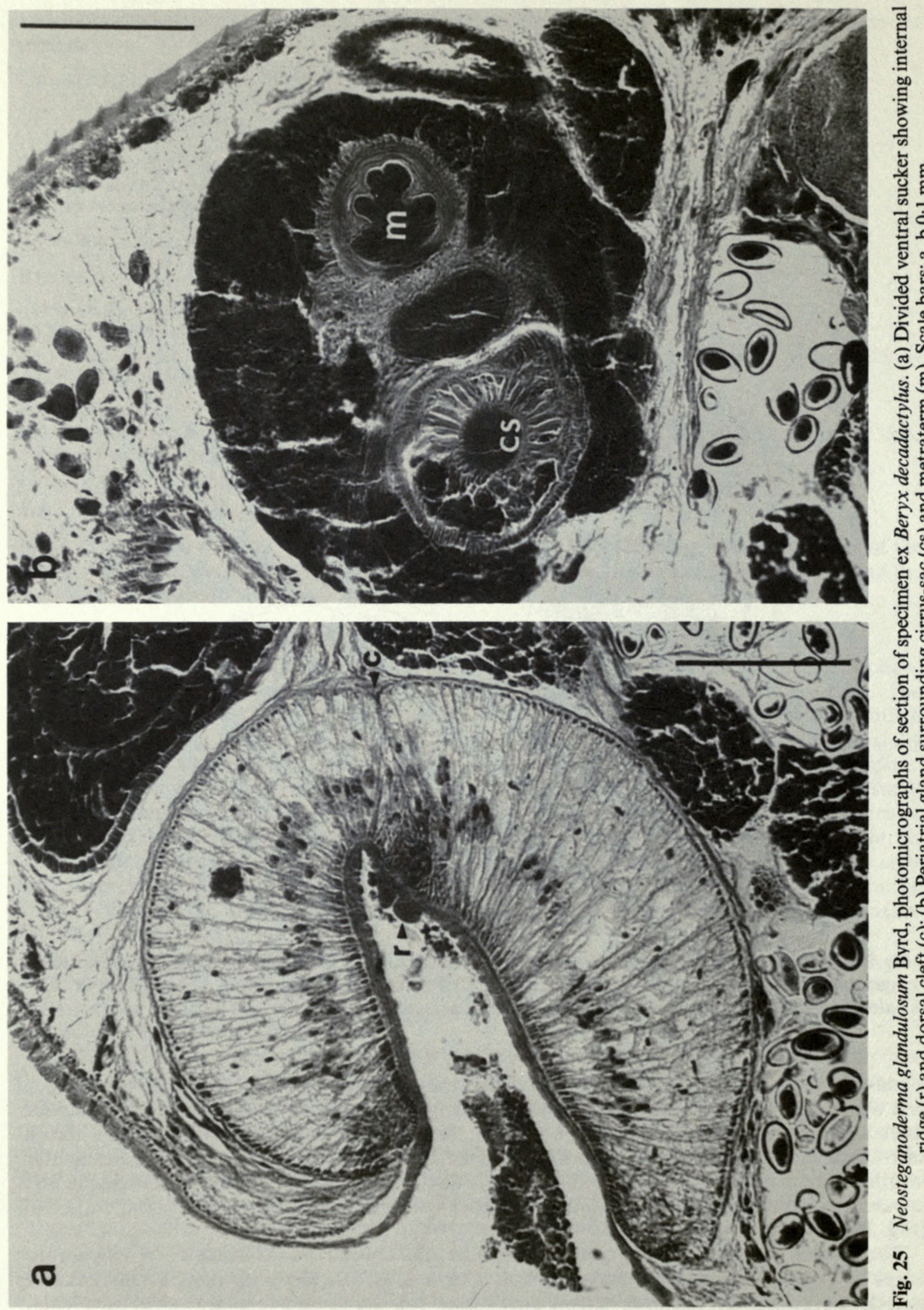
seminal receptacle and a narrow, undulating Laurer's canal which opens at about the level of the posterior part of the seminal receptacle (Fig. 24C). The oviduct also receives the common vitelline duct, the vitelline collecting ducts having, apparently, anastomosed close to the oviduct. From Mehlis' gland the uterus passes ventrally to fill most of the post-testicular region and the region ventral to the gonads with small, tanned, operculate eggs. The metraterm is a long tube, which, as it approaches the genital atrium, becomes increasingly muscular and develops an internally rugate wall. For much of its length it is ensheathed by an extension of the periatrial gland. It enters the genital atrium through the dorsal wall. The vitellarium consists of two lateral fields of about four to eight follicles which lie immediately posterior to the ventral sucker.

Discussion. Proctophantastes polymixiae Yamaguti, 1970, from Polymixia japonica from off Hawaii is very similar to $N$. glandulosum. Yamaguti (1970) did not compare the two species, but Bray (1973) suggested that they might be conspecific. There appears to be no substantial morphological difference between the species and they have been recorded in closely related hosts although in widely separated geographical areas. Korotaeva's (1982) record of Neosteganoderma polymixiae from the zeid fishes Cyttus novaezealandiae and Cyttoidops mccullochi in the Australia/New Zealand region extends the known distribution of that species, so that at present there seems no good reasons why $N$. glandulosum and $P$. polymixiae should be considered distinct. Examination of the holotype of $N$. glandulosum (USNM 60166) and of the holotype and paratypes of Proctophantastes polymixiae (USNM 63568) clearly shows the equatorial division of the ventral sucker.

\section{Genus PROCTOPHANTASTES Odhner, 1911}

DiAGNOSTIC FEATURES. Body small, pyriform. Caeca reach to level of vitellarium or testes. Ventral sucker large, divided equatorially by dorsal cleft and ventral ridge. Testes symmetrical to oblique in anterior hindbody. Cirrus-sac straight to curved. Seminal vesicle coiled tubular. Pars prostatica wide, vesicular. Ejaculatory duct bears 'spines'. Genital atrium small. Periatrial gland as separated claviform sacs. Genital pore sinistral, marginal; in mid-forebody. Ovary submedian, pretesticular. Uterus mostly post-testicular. Metraterm muscular. Vitellarium two symmetrical, lateral fields of few follicles; pre-testicular; in anterior hindbody. Excretory pore terminal; vesicle elongate saccular. In intestine of marine teleosts.

Comment. Bray (1973), following the work of Manter (1947), considered Proctophantastes a synonym of Steganoderma Stafford, 1904. He described a 'low muscular ridge' running transversely across the inside of the ventral sucker. Careful observation of serial sections show that the sucker is in fact divided equatorially by this ridge and a narrow, dorsal cleft. This suggests that Proctophantastes is very similar to Neosteganoderma (whose type-species, at least, has this type of sucker development) and differs only in the simple, unpocketed genital atrium and the weak development of the periatrial gland. The structure of the ventral sucker, however, serves as a useful feature differentiating Proctophantastes and Steganoderma, thus reversing Bray's earlier decision. The difference between the periatrial gland of Neosteganoderma (Fig. 25b) and the small tubular or claviform agglomerations of gland-cells surrounding the genital atrium and metraterm of Proctophantastes (Fig. 27c) should be stressed. The periatrial gland is an undivided large mass of gland-cells, possibly delimited by a membranous sac. In contrast, the few gland cells in Proctophantastes lie in narrow tubular or claviform membranous packets which are sparsely scattered in the parenchyma.

\section{Proctophantastes abyssorum Odhner, 1911}

Deretrema abyssorum (Odhner, 1911) Price, 1934.

Steganoderma abyssorum (Odhner, 1911) Manter, 1947.

TYPE-HOST AND LOCALITY. Coryphaenoides rupestris, Trondheim, Norway. 


\section{RECORDS}

(i) Material studied from the NE Atlantic region

Coelorinchus caelorhinchus [intestine] Northern Bay of Biscay $\left(47^{\circ} \mathrm{N}, 06^{\circ} \mathrm{W}\right.$; depth $650 \mathrm{~m}$; Jan., 1971). $\mathrm{BM}(\mathrm{NH})$ 1973.5.17.48-50. Material of Bray (1973: 167).

- [intestine] Southern Bay of Biscay $\left(44^{\circ} \mathrm{N}, 07^{\circ} \mathrm{W}\right.$; depth $340-350 \mathrm{~m}$; Jan., 1971). BM(NH) 1973.5.17.48-50. Material of Bray (1973: 167).

- [intestine] St Kilda, NW Scotland $\left(57^{\circ} \mathrm{N}, 10^{\circ} \mathrm{W}\right.$; depth $650-660 \mathrm{~m}$; June, 1974). BM(NH) 1984.2.24.1.

Lepidion eques [intestine] Northern Bay of Biscay $\left(47^{\circ} \mathrm{N}, 06^{\circ} \mathrm{W}\right.$; depth $650 \mathrm{~m}$; Jan., 1971). BM(NH) 1973.5.17.51-53. Material of Bray (1973: 167).

- [intestine] WSW Barra Head, NW Scotland $\left(57^{\circ} \mathrm{N}, 09^{\circ} \mathrm{W}\right.$; depth 656-665 m; May, 1973). BM(NH) 1984.2.24.2-4.

Phycis blennoides [intestine] NW of Rona, NW Scotland $\left(60^{\circ} \mathrm{N}, 07^{\circ} \mathrm{W}\right.$; depth $900 \mathrm{~m}$; May, 1973). BM(NH) 1984.2.24.5-6.

Rhinonemus cimbrius [intestine] Tjärnö, Sweden. (June, 1971). Material of J. Thulin.

Trachyrincus trachyrincus [intestine] Northern Bay of Biscay $\left(47^{\circ} \mathrm{N}, 06^{\circ} \mathrm{W}\right.$; depth $330-650 \mathrm{~m}$; Jan., 1971).

BM(NH) 1973.5.17.42-47. Material of Bray (1973: 167).

- [intestine] Southeastern Bay of Biscay $\left(45^{\circ} \mathrm{N}, 02^{\circ} \mathrm{W}\right.$; depth $575-665 \mathrm{~m}$; Jan., 1971). BM(NH) 1973.5.17.42-47. Material of Bray (1973: 167).

- [rectum] NW of Scotland $\left(58^{\circ} \mathrm{N}, 10^{\circ} \mathrm{W}\right.$; depth $1300-1310 \mathrm{~m}$; and $57^{\circ} \mathrm{N}, 09^{\circ} \mathrm{W}$; depth $1330-1350 \mathrm{~m}$; Oct., 1978). BM(NH) 1984.2.24.7-9.

(ii) NE Atlantic records from the literature

Coelorinchus caelorhinchus [intestine] Bay of Biscay. Bray (1973: 167).

Coryphaenoides rupestris [posterior intestine] Trondheim, Norway. (1905). Odhner (1911a: 238).

Lepidion eques [intestine] Bay of Biscay. Bray (1973: 167).

Melanogrammus aeglefinus [posterior intestine] Trondheim, Norway. (1905). Odhner (1911a: 238).

Trachyrincus trachyrincus [intestine] Bay of Biscay. Bray (1973: 167)

AsPECTS OF BIOLOGY. Nothing is known of the life-history of this parasite. It occurs only in gadiform fishes in the north-east Atlantic region and appears to show a predeliction for fishes from the deeper waters, having been found as deep as $1350 \mathrm{~m}$.

PREVIOUS DESCRIPTIONS. Odhner (1911a: 238); Bray (1973: 167).

DESCRIPTION (Figs 26, 27). Seventy-two whole-mounts and two sets of serial sections were studied. Measurements are given on Table 14. The worm has a pyriform to elongate pyriform outline (Fig. 26A), with a spinous body-surface in the forebody and most of the hindbody. The subterminal globular oral sucker leads to a short, often obscured, prepharynx, a small, globular to slightly oval pharynx, and a distinct oesophagus which bifurcates in about the middle of the forebody. The caeca reach to the level of the testes or vitellarium. The ventral sucker is distinctive in that it is large, often transversely elongate, and divided equatorially by a ventral muscular ridge and a dorsal cleft (Fig. 27a,b).

The terminal excretory pore leads through a narrow duct surrounded by a few gland-cells, into a flattened sac-like vesicle which reaches up to about the level of the testes.

The testes are oval to elongate-oval and lie symmetrically or subsymmetrically close to the posterior margin of the ventral sucker. The proximity of the testes to the ventral sucker depends on the degree of contraction of the worm (see Bray, 1973, fig. 7), but they are often separated from the sucker by some of the vitelline follicles. The cirrus-sac is large, often recurved, and overlaps the anterior edge of the ventral sucker (Fig. 26B). The seminal vesicle is a coiled tube with the proximal portion occasionally forming a globular sac. It leads into an elongate, vesicular pars prostatica and thence into a muscular ejaculatory duct lined with tegumental rugae and pinnacles. The cirrus-sac also contains numerous gland-cells. The cirrus-sac opens into a distinct, but small, genital atrium which opens on or near the left lateral margin at about the middle of the forebody. Around the genital atrium and distal regions of cirrus-sac and metraterm are tubular to claviform membranous sacs containing gland cells, which may be indistinct (Figs 26A, 27c) or quite well developed (Fig. 26B). 

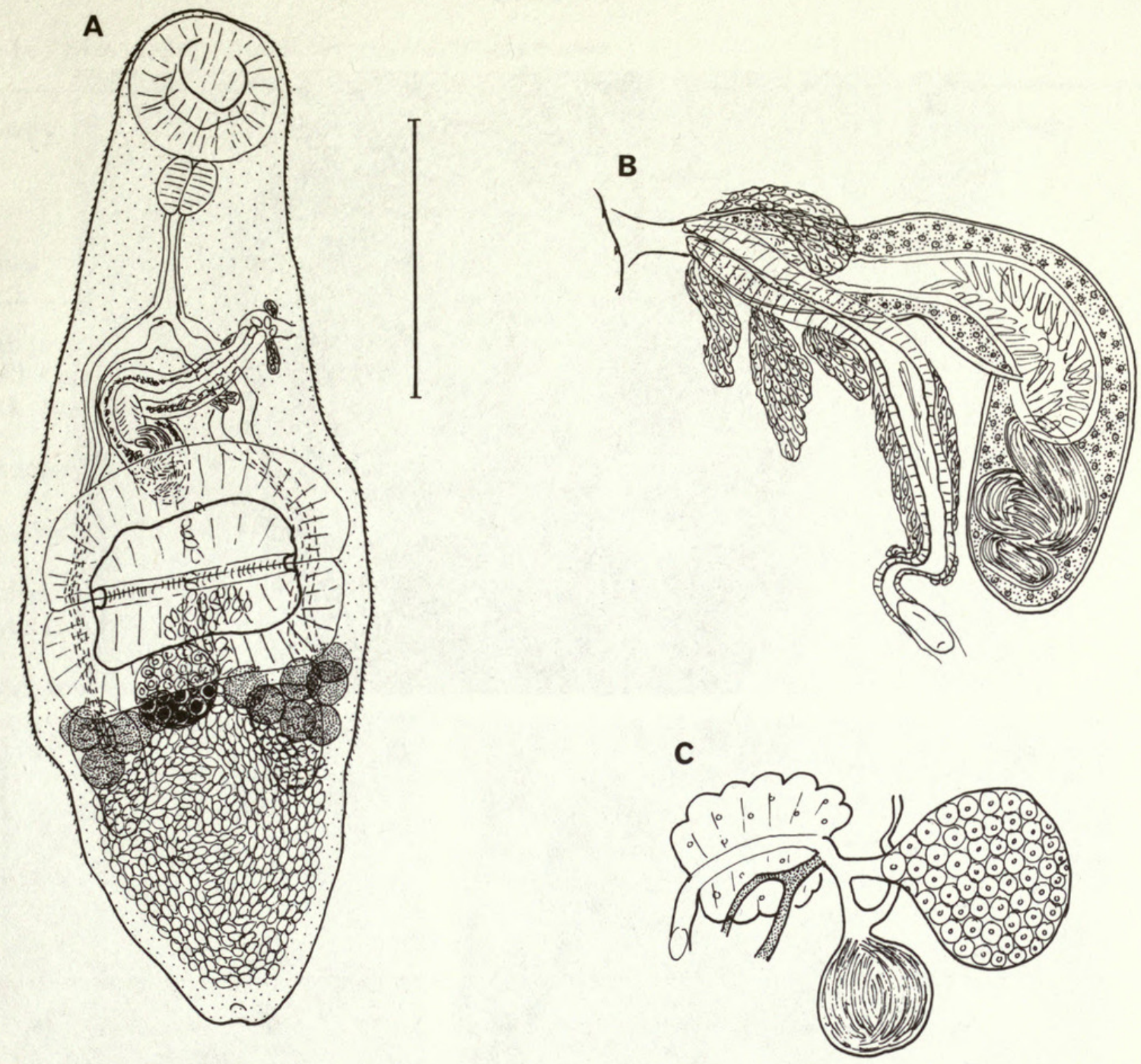

Fig. 26 Proctophantastes abyssorum Odhner. (A) Ventral view of specimen ex Trachyrincus trachyrincus; (B) Dorsal view of terminal genitalia of specimen ex Coelorinchus caelorhinchus; (C) Proximal female genitalia. Scale bar: $0.5 \mathrm{~mm}$.

The ovary is more or less globular and lies just antero-medial to the right testis, at the level of the posterior edge of the ventral sucker. From its left side an oviduct passes towards a prominent Mehlis' gland. It receives the common duct from the seminal receptacle and Laurer's canal and the common vitelline duct prior to entering Mehlis' gland. The subglobular, seminal receptacle is often of a similar size to the ovary, posteriorly to which it lies. The duct leading from the oviduct to the seminal receptacle is short, and gives rise to Laurer's canal near its distal end. Laurer's canal passes anteriorly, following a convoluted course and surrounded by gland-cells, to open dorsally just anteriorly to the ovary (Fig. 26C). The common vitelline duct is a slightly enlarged reservoir fed to two narrow collecting ducts. Mehlis' gland lies to the left of the ovary and the uterus passes posteriorly from it and fills much of the hindbody. It contains numerous strongly-tanned operculate eggs. The metraterm is muscular and runs beside the cirrus-sac prior to entering the genital atrium dorsally. It is invested for part of its length by a narrow layer of gland-cells. The vitellarium consists of two symmetrical clusters of distinct, globular follicles, lying on either side of the body at the posterior margin of the ventral sucker. The clusters consist of 8 to 10 follicles on the poral side and 7 to 9 on the aporal.

Discussion. This species is very similar to the only other member of the genus, $P$. gillissi (Overstreet \& Pritchard, 1977) n. comb., which is recorded from the Pacific Ocean. Slight differences in size and sucker-ratio constitute the only morphological differentiating features. 

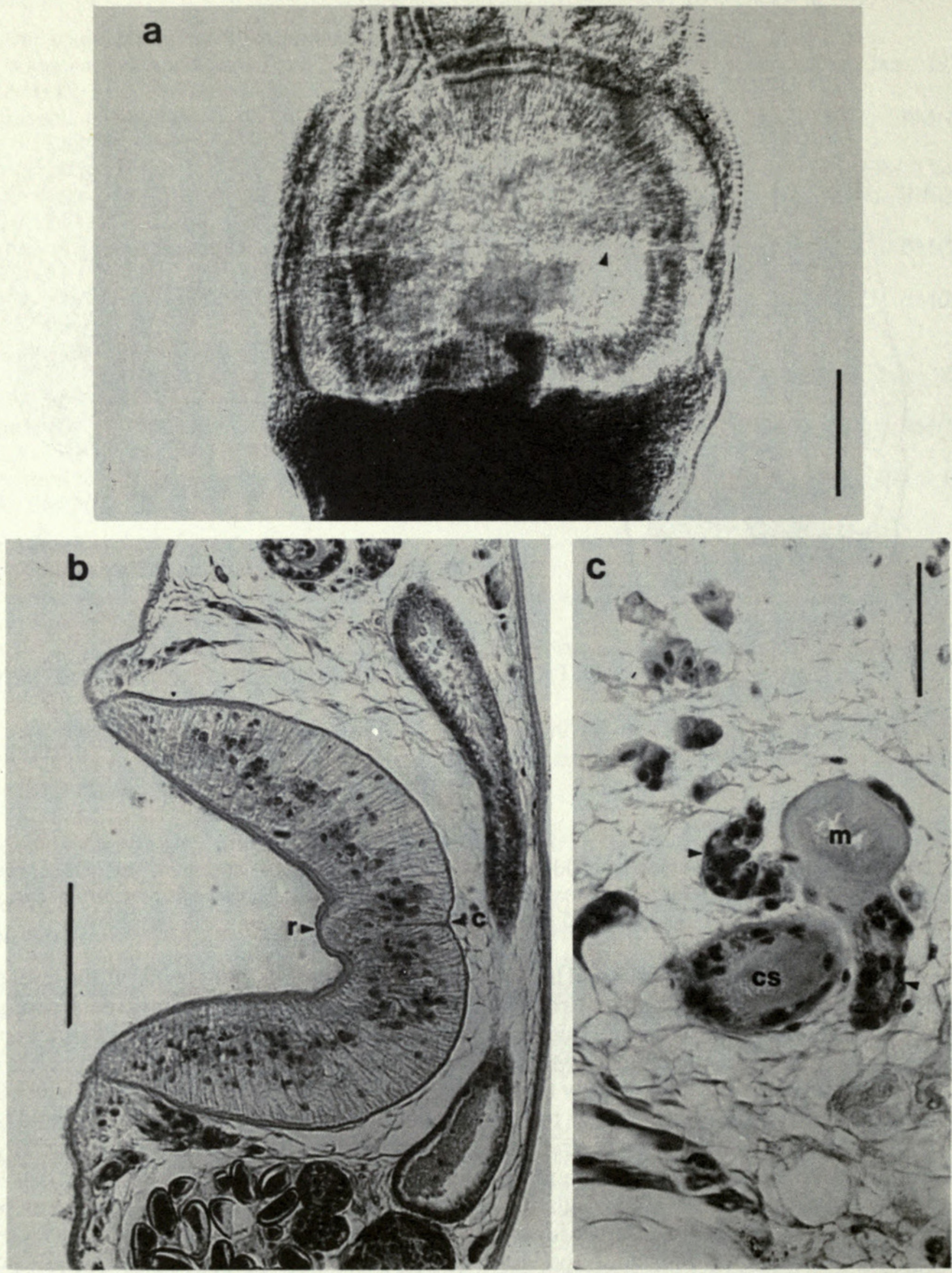

Fig. 27 Proctophantastes abyssorum Odhner. (a) Ventral sucker showing division (arrowed), ex Trachyrincus trachyrincus; (b) Longitudinal section of divided ventral sucker showing internal ridge (r) and dorsal cleft (c), ex Phycis blennoides; (c) Longitudinal section of distal end of cirrus-sac (cs), metraterm (m) and claviform membranous sacs containing gland-cells (arrowed), ex P. blennoides. Scale bars: a $0.2 \mathrm{~mm}, \mathrm{~b} 0.1 \mathrm{~mm}, \mathrm{c} 0.05 \mathrm{~mm}$. 
Table 14 Measurements of Proctophantastes abyssorum

\begin{tabular}{|c|c|c|c|}
\hline Authority & Odhner (1911a) & Bray (1973) & Present study \\
\hline Host & $\begin{array}{l}\text { Coryphaenoides } \\
\text { Melanogrammus }\end{array}$ & see text & see text \\
\hline Locality & Norway & see text & see text \\
\hline Length (mm) & $0 \cdot 8-1 \cdot 1$ & $0.62-1.66$ & $0.85-1.65$ \\
\hline Breadth (mm) & $0.35-0.4$ & $0.28-0.63$ & $0.37-0.70$ \\
\hline $\begin{array}{l}\text { Length : forebody } \\
\text { ratio }\end{array}$ & - & - & $1: 0.34-0.54$ \\
\hline Oral sucker $(\mathrm{mm})$ & 0.25 diam. & $\begin{array}{c}0 \cdot 18-0 \cdot 32 \\
\text { diam. }\end{array}$ & $\begin{array}{r}0.15-0.26 \times \\
0 \cdot 16-0.29\end{array}$ \\
\hline $\begin{array}{l}\text { Ventral sucker } \\
(\mathrm{mm})\end{array}$ & $0.35 \times 0.45$ & $\begin{array}{r}0.18-0.44 \times \\
0.25-0.60\end{array}$ & $\begin{array}{r}0.20-0.45 \times \\
0.33-0.63\end{array}$ \\
\hline Sucker-ratio & - & $1: 1 \cdot 08-2 \cdot 1$ & $1: 1 \cdot 42-3 \cdot 1$ \\
\hline Pharynx (mm) & 0.06 diam. & $\begin{array}{l}0.03-0.08 \\
\text { diam. }\end{array}$ & $\begin{array}{r}0.05-0.10 \times \\
0.05-0.10\end{array}$ \\
\hline Oesophagus (mm) & $\begin{array}{l}1-2 \cdot 5 \times \\
\text { pharynx }\end{array}$ & $0.08-0.22$ & $0.065-0.15$ \\
\hline Cirrus-sac (mm) & - & $\begin{array}{c}0.2-0.37 \times \\
0.06-0.09\end{array}$ & $\begin{array}{r}0.28-0.66 \times \\
0.06-0.12\end{array}$ \\
\hline Testes (mm) & - & $\begin{array}{r}0.16-0.22 \times \\
0.13-0.20\end{array}$ & $\begin{array}{r}0 \cdot 10-0 \cdot 23 \times \\
0.08-0.12\end{array}$ \\
\hline Ovary (mm) & - & c. 0.15 diam. & $\begin{array}{r}0 \cdot 11-0 \cdot 15 \times \\
0 \cdot 10-0 \cdot 12\end{array}$ \\
\hline Eggs $(\mu \mathrm{m})$ & $34-37 \times 18$ & $34-31 \times 16-21$ & $33-38 \times 15-19$ \\
\hline
\end{tabular}

Genus STEGANODERMA Stafford, 1904

Lecithostaphylus Odhner, 1911.

Nordosstrema Issaitschikov, 1928.

Manteroderma Skrjabin, 1957.

Cypseluritrema Yamaguti, 1970.

Steganoderma (Opisthoarchiotrema) Gupta \& Sharma, 1974.

DIAGNOSTIC FEATURES. Body oval to elongate-oval. Body-surface spinous. Oesophagus absent to long; caeca reach to testes or beyond. Ventral sucker globular, subequal or larger than oral, sessile or pedunculate. Testes oval, symmetrical to oblique in anterior half of hindbody. Cirrus-sac claviform, straight or curved. Seminal vesicle saccular to elongate, straight or coiled. Pars prostatica vesicular. Genital atrium small. Genital pore sinistral, lateral to sublateral, in forebody. Ovary pre-testicular, usually in hindbody. Eggs tanned. Uterus mainly post-testicular. Vitellarium symmetrical, relatively few (8-16) regular follicles, in lateral regions of anterior hindbody. Excretory pore terminal; vesicle saccular, short to long. Parasitic in intestine of marine teleosts.

COMmENT. Only one species, $S$. (Lecithostaphylus) retroflexum, has hitherto been found in the north-east Atlantic. It may well be that $S$. (Steganoderma) formosum Stafford, 1904 will be found eventually, as it occurs both in the north-western Atlantic and the Barents Sea (Bray, in press $b$ ).

Steganoderma (Lecithostaphylus) retroflexum (Molin, 1859) Yamaguti, 1953

Distomum retroflexum Molin, 1859.

Podocotyle retroflexum (Molin, 1859) Barbagallo \& Drago, 1903.

Lecithostaphylus retroflexum (Molin, 1859) Odhner, 1911. 
Steganoderma retroflexum (Molin, 1859) Manter, 1947.

Lecithostaphylus spondyliosomae Fantham, 1938.

Steganoderma spondyliosomae (Fantham, 1938) Manter, 1947.

Steganoderma (Lecithostaphylus) spondyliosomae (Fantham, 1938) Yamaguti, 1953.

Manteroderma spondyliosomae (Fantham, 1938) Skrjabin, 1957.

TYPE-HOST AND LOCALITY. Belone belone, Padua, Italy.

\section{RECORDS}

(i) Material studied

(a) From the NE Atlantic

Belone belone [intestine] Lisbon, Portugal. BM(NH) 1984.2.29.1.

(b) From elsewhere

Belone belone [intestine] Split, Yugoslavia. Material of O. Sey.

— [intestine] Zadar, Yugoslavia. BM(NH) 1984.2.29.2.

(ii) NE Atlantic records from the literature

None, but Gijon, Lopez-Roman, De Armas \& Valladares (1982) recorded it from the Canary Islands.

AsPeCTS OF BIOLOGY. Odhner (1911b) believed that Cercaria thaumantiatis Graeffe, 1860, from a coelenterate was the larval stage of this species, but it is now considered likely to be the larva of Lepocreadium album (Stossich, 1890) (Dollfus, 1925; Palombi, 1931). The great majority of records of this worm are from Belone belone, and its possible synonym Belone acus, in the Mediterranean Sea. Barbagallo \& Drago (1903) recorded it in the flying fish, Exocoetus volitans, and Papoutsoglou (1976) listed the wrasse, Labrus merula, as a host. Both records are from the Mediterranean. The finding of a worm indistinguishable from $S$. retroflexum in the local sparid Pachymetopon blochii in a marine aquarium at Cape Town, South Africa (Fantham, 1938; as Lecithostaphylus spondyliosomae), considerably widens the known distribution.

PreVIOUS DESCRIPTIONS Molin (1859:290); Odhner (1911 $b: 115)$; Timon-David (1937b:4); Fantham (1938: 387).

DESCRIPTION (Fig. 28). Three good specimens and some poorly fixed and fragmentary specimens were available for study. The measurements are given on Table 15. The body has an elongate-oval outline (Fig. 28A), and the surface of these specimens has apparently lost its (usually reported) spines. The globular oral sucker opens subterminally leading to a short prepharynx, large globular pharynx and a short or practically absent oesophagus. The intestinal bifurcation, which occurs in the mid-forebody, gives rise to narrow caeca which reach into the post-testicular region, usually significantly but often only slightly. The globular ventral sucker is borne on a short, protrusible peduncle which may be visible in ventrally mounted preparations as a series of ridges around the sucker. Alternatively it may be deeply withdrawn into the body, but when this occurs clear evidence of the peduncle in the shape of folds around the sucker is apparent. The oral and ventral suckers are of similar sizes. Numerous flask-shaped glandular cells can be seen in the lateral forebody region and reach just into the hindbody.

The excretory pore is terminal, but in the specimens available it was not possible to make out the full extent of the vesicle.

The longitudinally elongate, oval testes lie symmetrically in the mid-hindbody. The elongateoval cirrus-sac, usually just reaching or overlapping the ventral sucker, contains a claviform, saccular seminal vesicle, a short, vesicular pars prostatica and a short ejaculatory duct, all surrounded by gland-cells (Fig. 28B). It opens into a distinct genital atrium which is surrounded by gland-cells. The genital pore is sinistral, submarginal and at the level of the pharynx or just posterior to it.

The ovary is longitudinally elongate oval, lies about half-way between the testes and the ventral sucker, and is separated from the testes by uterine coils. The seminal receptacle and Mehlis' gland lie just posteriorly to the ovary. Laurer's canal opens dorsally at the level of the posterior margin of the ovary. The uterus, containing numerous tanned, operculate eggs, fills much of the hindbody. Post-testicularly it reaches close to the lateral margins of the worm, but is restricted pre-testicularly 

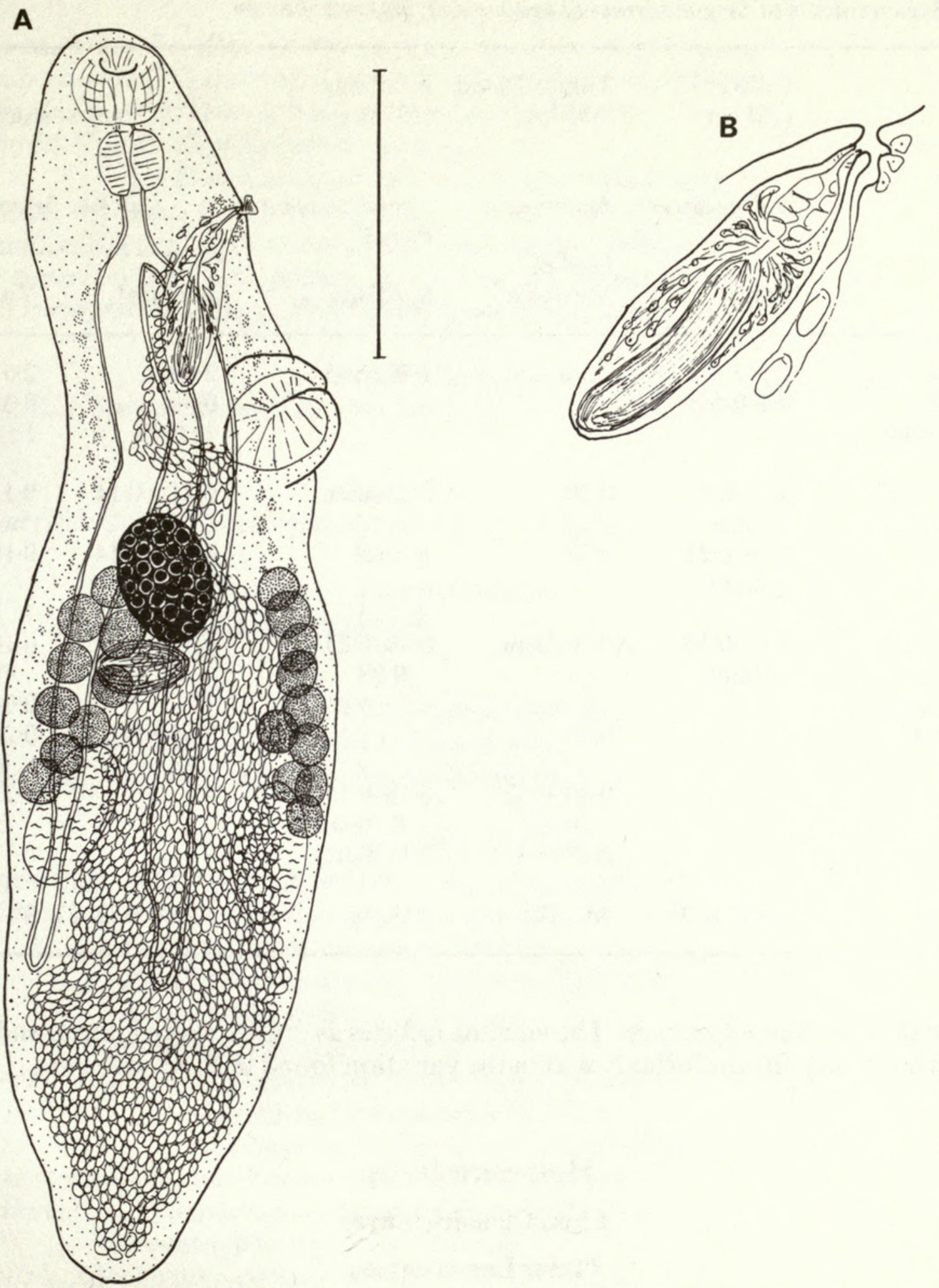

Fig. 28 Steganoderma (Lecithostaphylus) retroflexum (Molin). (A) Flattened specimen; (B) Terminal genitalia. Scale bar: $0.5 \mathrm{~mm}$.

to the regions median to the vitelline follicles. The metraterm is weakly developed. The vitellarium consists of two lateral fields of regular follicles arranged 6 to 11 on the poral side and 8 to 9 on the aporal side. Anteriorly the vitelline field reaches from the level of the ovary to the level of the ventral sucker and posteriorly it just overlaps the anterior edge of the testes. The field of flask-shaped gland-cells mentioned above may reach back almost to the posterior region of the vitellarium.

Discussion. Lecithostaphylus spondyliosomae Fantham, 1938, is indistinguishable morphologically from $S$. retroflexum and is, therefore, considered a synonym. It is said to differ in having more oblique testes and fewer vitelline follicles. The testes in the figure, however, are precisely symmetrical. This figure, in fact, is very similar to that of S. retroflexum in Odhner (1911b): they 
Table 15 Measurements of Steganoderma (Lecithostaphylus) retroflexum

\begin{tabular}{|c|c|c|c|c|c|}
\hline Authority & $\begin{array}{l}\text { Odhner } \\
(1911 b)\end{array}$ & $\begin{array}{l}\text { Timon-David } \\
(1937 b)\end{array}$ & $\begin{array}{l}\text { Fantham } \\
\text { (1938) }\end{array}$ & \multirow{2}{*}{\multicolumn{2}{|c|}{$\begin{array}{l}\text { Present study } \\
\text { Belone belone }\end{array}$}} \\
\hline Host & Belone acus & Belone acus & Spondyliosoma & & \\
\hline Locality & Italy & Marseille & S. Africa & Portugal & Yugoslavia \\
\hline Length (mm) & $1 \cdot 5-2 \cdot 5$ & $2 \cdot 5$ & $1.42-1.45$ & $2 \cdot 03$ & $2 \cdot 01-2 \cdot 18$ \\
\hline Breadth (mm) & $0.4-0.55$ & - & - & 0.40 & $0.38-0.56$ \\
\hline $\begin{array}{l}\text { Length : forebody } \\
\text { ratio }\end{array}$ & - & - & - & $1: 0 \cdot 23$ & $1: 0.24-0.31$ \\
\hline Oral sucker (mm) & $\begin{array}{c}0 \cdot 15-0 \cdot 2 \\
\text { diam. }\end{array}$ & $0 \cdot 19$ & 0.13 diam. & $0.11 \times 0.14$ & $\begin{array}{r}0.13-0 \cdot 14 \times \\
0 \cdot 13-0.16\end{array}$ \\
\hline $\begin{array}{l}\text { Ventral sucker } \\
(\mathrm{mm})\end{array}$ & $\begin{array}{c}0 \cdot 18-0 \cdot 23 \\
\text { diam. }\end{array}$ & $0 \cdot 22$ & \pm oral & $0.14 \times 0.14$ & $0.19 \times 0.16$ \\
\hline Sucker-ratio & - & - & $\pm 1: 1$ & $1 ; 1$ & $1: 1 \cdot 15$ \\
\hline Pharynx (mm) & $\begin{array}{l}0 \cdot 12-0 \cdot 16 \\
\text { diam. }\end{array}$ & $0 \cdot 16$ diam. & $\begin{array}{c}0.08-0.85 \times \\
0.09\end{array}$ & $0.11 \times 0.10$ & $\begin{array}{r}0 \cdot 10-0 \cdot 12 \times \\
0.08-0.12\end{array}$ \\
\hline Oesophagus (mm) & - & - & - & - & 0.08 \\
\hline Cirrus-sac (mm) & - & 0.40 & - & $0.35 \times 0.12$ & $\begin{array}{r}0.26-0.34 \times \\
0.09-0.11\end{array}$ \\
\hline Testes (mm) & - & $\begin{array}{c}0 \cdot 40-0 \cdot 42 \\
\text { long }\end{array}$ & $\begin{array}{c}0 \cdot 18-0 \cdot 195 \times \\
0 \cdot 10-0.13\end{array}$ & - & $\begin{array}{r}0 \cdot 25-0 \cdot 31 \times \\
0 \cdot 12-0.17\end{array}$ \\
\hline Ovary (mm) & - & $0 \cdot 17$ & $0 \cdot 13$ diam. & - & $\begin{array}{r}0 \cdot 17-0 \cdot 22 \times \\
0 \cdot 11-0 \cdot 16\end{array}$ \\
\hline Eggs $(\mu \mathrm{m})$ & $38-41 \times 20$ & $40 \times 20$ & 40 long & $36-40 \times 20-21$ & $37-41 \times 20-25$ \\
\hline
\end{tabular}

could almost be of the same specimen. The vitelline follicles as drawn, seven aporal, and nine poral (in L. spondyliosomae), fit comfortably within the variation found in S. retroflexum.

\section{Host-parasite list \\ Class Chondrichthyes}

Order Lamniformes

Scyliorhinus caniculus (L.): Diphterostomum betencourti (Monticelli)

Scyliorhinus stellaris (L.): Diphterostomum betencourti (Monticelli)

Order Squaliformes

Squalus acanthias (L.): Pseudozoogonoides sp. innom.

\section{Class Osteichthyes}

\section{Order Notacanthiformes}

Notacanthus chemnitzii Bloch: Panopula spinosa (Zubchenko)

Polyacanthonotus rissoanus (Filippi \& Verany): Brachyenteron campbelli sp. nov.

Panopula bridgeri sp. nov. 


\section{Order Gadiformes}

Coelorinchus caelorhinchus (Risso): Proctophantastes abyssorum Odhner

Coryphaenoides rupestris Gunnerus: Proctophantastes abyssorum Odhner

Lepidion eques (Günther): Proctophantastes abyssorum Odhner

Lycodes esmarkii Collet: Lepidophyllum appyi sp. nov.

Pseudozoogonoides subaequiporus (Odhner)

Melanogrammus aeglefinus (L.): Proctophantastes abyssorum (Odhner)

Phycis blennoides (Brünnich): Proctophantastes abyssorum (Odhner)

Rhinonemus cimbrius (L.): Proctophantastes abyssorum (Odhner)

Trachyrincus trachyrincus (Risso): Proctophantastes abyssorum (Odhner)

Order Atheriniformes

Belone belone (L.): Steganoderma (Lecithostaphylus) retroflexum (Molin)

Order Beryciformes

Beryx decadactylus Cuvier: Neosteganoderma glandulosum Byrd

Zeus faber L.: Zoogonoides viviparus (Olsson)

\section{Order Zeiformes}

\section{Order Scorpaeniformes}

Myoxocephalus scorpius (L.): Zoogonoides viviparus (Olsson)

Taurulus bubalis (Euphrasèn): Zoogonoides viviparus (Olsson)

\section{Order Perciformes}

Anarhichas denticulatus (Krøyer): Brachyenteron pycnorganum (Rees)

Anarhichas lupus L.: Brachyenteron pycnorganum (Rees)

Lepidophyllum steenstrupi Odhner

Pseudozoogonoides subaequiporus (Odhner)

Zoogonoides viviparus (Olsson)

Zoogonus rubellus (Olsson)

Anarhichas minor Olafsen: Brachyenteron pycnorganum (Rees)

Lepidophyllum steenstrupi Odhner

Pseudozoogonoides subaequiporus (Odhner)

Blennius gattorugine Brünnich: Zoogonoides viviparus (Olsson)

Blennius ocellaris L.: Diphterostomum brusinae (Stossich)

Zoogonoides viviparus (Olsson)

Blennius pholis L.: Zoogonus rubellus (Olsson)

Chelon labrosus (Risso): (?) Diphterostomum betencourti (Monticelli)

Diplodus sargus (E. Geoffroy Saint-Hilaire): (?) Diphterostomum brusinae (Stossich)

Gobius niger L.: Zoogonoides viviparus (Olsson)

Labrus bergylta Ascanius: Zoogonus rubellus (Olsson)

Labrus bimaculatus L.: Zoogonus rubellus (Olsson)

Pagellus bogaraveo (Brünnich): Diphterostomum vividum (Nicoll)

Pomatoschistus minutus (Pallas): Zoogonoides viviparus (Olsson)

Trachurus trachurus (L.): Zoogonoides viviparus (Olsson)

Zoogonus rubellus (Olsson)

Callionymus lyra L.: Zoogonoides viviparus (Olsson)

\section{Order Gobiesociformes}

Callionymus maculatus Rafinesque: Zoogonoides viviparus (Olsson)

Callionymus reticulatus Valenciennes: Zoogonoides viviparus (Olsson) 


\section{Order Pleuronectiformes}

Glyptocephalus cynoglossus (L.): Zoogonoides viviparus (Olsson)

Hippoglossoides platessoides (Fabricius): Pseudozoogonoides subaequiporus (Odhner)

Zoogonoides viviparus (Olsson)

Hippoglossus hippoglossus (L.): Zoogonoides viviparus (Olsson)

Lepidorhombus whiffiagonis (Walbaum): Zoogonoides viviparus (Olsson)

Limanda limanda (L.): Zoogonoides viviparus (Olsson)

Zoogonus rubellus (Olsson)

Microchirus variegatus (Donovan): Zoogonoides viviparus (Olsson)

Microstomus kitt (Walbaum): Zoogonoides viviparus (Olsson)

Platichthys flesus (L.): Zoogonoides viviparus (Olsson)

Zoogonus rubellus (Olsson)

Pleuronectes platessa (L.): Zoogonoides viviparus (Olsson)

Zoogonus rubellus (Olsson)

Psetta maxima (L.): Zoogonoides viviparus (Olsson)

Solea vulgaris (Quensel): Zoogonoides viviparus (Olsson)

\section{Acknowledgements}

The authors would like to thank the following for help during this study: the crews of the research vessels Cirolana, G. A. Reay, Explorer, Scotia and Jassa; Dr A. Jamieson, Mr R. J. Turner, Mr J. Nichols, Mr R. W. Blacker, Mr J. P. Bridger and Dr C. T. Macer of the MAFF Laboratory, Lowestoft; Dr A. H. McVicar, Dr J. W. Smith, Dr R. Wootten and Dr K. MacKenzie of the DAFS Laboratory, Aberdeen; Mrs F. Franklin of the MAFF Laboratory, Burnham-on-Crouch; Dr B. F. Matthews of Plymouth Polytechnic; Mr A. Mattacola of the Marine Biological Association, Plymouth; Professor M. D. B. Burt of The University of New Brunswick, Fredericton, Canada; Dr J. S. Scott of the Marine Laboratory, St Andrews, New Brunswick, Canada; Dr R. G. Appy of the University of Guelph, Canada; Dr E. M. Burreson of the Virginia Institute of Marine Science, Gloucester Point, USA; Dr M. Køie of the Marine Biological Laboratory, Helsingør, Denmark; Dr A. V. Gaevskaya of AtlantNIRO, Kaliningrad, USSR; Dr J. R. Lichtenfels, USDA, Beltsville, Maryland, USA; Dr M. H. Pritchard of the Harold Manter Laboratory, Lincoln, Nebraska, USA; Dr Shunya Kamegai of the Meguro Parasitological Museum, Tokyo, Japan; Dr O. Sey, Janus Pannonius University, Pecs, Hungary; Dr J. Thulin of the National Swedish Environment Protection Board, Öregrund, Sweden; Professor H. H. Williams, Open University in Wales, Cardiff.

The following colleagues at the British Museum (Natural History) have also helped us: Miss S. Fairman, Ms S. Barnes, Mr D. Claugher (Electron Microscope Unit); Mr D. W. Cooper (Histology and Preservation Section); Mr P. V. York (Photographic Unit); Mrs H. Sabo (translator from the Russian); Mrs E. A. Harris (Parasitic Worms Section).

\section{References}

Africa, C. M. 1930. The excretory system of Cercariaeum lintoni Miller, 1926. Journal of Parasitology 17: $14-17$.

Aleshkina, L. D. 1979. Characteristics of trematode fauna in fish of the South-Eastern Atlantic. In: O. N. Bauer et al. (Eds), Tezisy Dokladov. VII All-Union Conference on parasites and diseases of fish. Nauka Leningradskoe Otdelenie: Leningrad, 5-6. (In Russian.)

Amato, J. F. R. 1983. Digenetic trematodes of percoid fishes of Florianópolis, Southern BrasilFellodistomidae, Monascidae, Diplangidae, Zoogonidae and Waretrematidae with description of two new species. Revista Brasileira de Biologia 42: 681-699.

Arai, H. P. 1954. Helminth parasites of embiotocid fishes. I. A new genus of the trematode family Zoogonidae. Journal of Parasitology 40: 356-359.

Barbagallo, P. \& Drago, U. 1903. Primo contributo allo studio della fauna elmintologica dei pesci della Sicilia orientale. Archives de Parasitologie 7: 408-427. 
Baylis, H. A. 1939. Further records of parasitic worms from British vertebrates. Annals and Magazine of Natural History (ser. II) 4: 437-498.

\& Jones E. I. 1933. Some records of parasitic worms from marine fishes at Plymouth. Journal of Marine Biological Association of the United Kingdom 18: 627-634.

Bayssade-Dufour, C. A. \& Maillard, C. 1974. Chetotaxie de quatre cercaires d'Allocreadioidea. Annales de Parasitologie humaine et comparée 49: 521-554.

Benazzi, M. \& Benazzi Lentati, G. 1976. Platyhelminthes. Animal Cytogenetics 1: 1-182.

Bray, R. A. 1973. Some digenetic trematodes in fishes from the Bay of Biscay and nearby waters. Bulletin of the British Museum (Natural History) (Zoology) 26: 151-183.

1979. Digenea in marine fishes from the eastern seaboard of Canada. Journal of Natural History 13: 399-431.

1985a. Some helminth parasites of marine fishes of South Africa: Families Gorgoderidae, Zoogonidae, Cephaloporidae, Acanthocolpidae and Lepocreadiidae (Digenea). Journal of Natural History 19: 377-405.

1985b. Studies on the helminth parasites of marine fishes, with emphasis on the Zoogonidae (Platyhelminthes: Digenea). PhD Thesis, Open University, $456 \mathrm{pp}$.

in press $a$. Revision of the digenean family Zoogonidae Odhner, 1902: Introduction and subfamily Zoogoninae. Systematic Parasitology.

- in press $b$. Revision of the digenean family Zoogonidae Odhner, 1902: Subfamily Lepidophyllinae and comments on some aspects of biology. Systematic Parasitology.

\& Gibson, D. I. 1977. The Accacoeliidae (Digenea) of fishes from the north-east Atlantic. Bulletin of the

British Museum (Natural History) (Zoology) 31: 51-99.

\& 1980. The Fellodistomidae (Digenea) of fishes from the northeast Atlantic. Bulletin of the British Museum (Natural History) (Zoology) 37: 199-293.

\& Rollinson, D. 1985. Enzyme electrophoresis as an aid to distinguishing species of Fellodistomum,

Steringotrema and Steringophorus (Digenea: Fellodistomidae). International Journal for Parasitology 15: 255-263.

Brinkmann, A. Jr. 1956. Trematoda. The Zoology of Iceland 2 (11): 1-34.

1967. Some trematodes from marine fishes in the waters of Rhodes. Arbokfor Universitetet i Bergen 10: 2-13.

1975. Trematodes from Greenland. Meddelelser om Grønland 205: 2-88.

Brooks, F. G. 1930. Studies on the germ cell cycle of trematodes. American Journal of Hygiene 12: 299-340.

Byrd, M. A. 1964. Neosteganoderma glandulosa gen. n., sp. n. (Trematoda: Steganodermatidae) from an Atlantic fish. Proceedings of the Helminthological Society of Washington 31: 105-108.

Campbell, R. A. 1975. Hudsonia agassizi gen. et sp. n. (Zoogonidae: Hudsoniinae subf. n.) from a deep-sea fish in the western North Atlantic. Journal of Parasitology 61: 409-412.

_ 1983. Allosteganoderma: A replacement name for Hudsonia Campbell, 1975. (Digenea: Zoogonidae). Journal of Parasitology 69: 889.

Cheng, T. C., Sullivan J. T. \& Harris, K. R. 1973. Parasitic castration of the marine prosobranch gastropod Nassarius obsoletus by sporocysts of Zoogonus rubellus (Trematoda): Histopathology. Journal of Invertebrate Pathology 21: 183-190.

Chubrik, G. K. 1966. Fauna and ecology of trematode larvae from molluscs in the Barents and White Seas. Trudy Murmanskii Biologicheskii Institut 10 (14): 78-166. (In Russian.)

Cooper, A. R. 1915. Trematodes from marine and fresh-water fishes including one species of ectoparasitic turbellarian. Transactions of the Royal Society of Canada (Sect 4; Ser 3) 9: 181-205.

Cordero del Campillo, M. 1975. Trematodos. In: Comisión para la compilación del índice-catalogo de Zooparásitos ibéricos. Instituto Bayer de Terapéutica Experimental, Barcelona, pp. 75-115.

Crofton, H. D. 1947. The parasites of some littoral fishes of Northumberland. Report Dove Marine Laboratory, Cullercoats, Third Series No. 9: 59-64.

Crothers, J. 1966. Dale Fort marine fauna. Field Studies 2 (Suppl.): xxiv + 169 pp.

Cuénot M. L. 1892. Commensaux et parasites de Échinodermes (Deuxième note). Revue Biologique du Nord de la France 5: 1-23.

DAFS (Department of Agriculture \& Fisheries for Scotland) 1972. Fish parasites and diseases. Directorate of Fisheries Research Report (1971): 33-46.

Dawes, B. 1947. The Trematoda of British fishes. Ray Society, London. 364 pp.

De Coursey, P. J. \& Vernberg, W. B. 1974. Double infections of larval trematodes: competitive interactions. In: W. B. Vernberg (Ed.), Symbiosis in the Sea. University of South Carolina Press, Columbia, pp. 93-109.

Diesing, K. M. 1858 Berichtigungen und Zusätze zur Revision der Cercarieen. Sitzungsberichte der Akademie der Wissenschaften, Mathematisch-Naturwissenschaftliche Classe. Wien 31: 239-290.

Dolgikh, A. V. 1965 a Larval trematodes-parasites of molluscs from the Crimean shore of the Black Sea. 
Autoreferat dissertachii na soiskanie uchenoj stepeni kandidata biologicheskikh nauk. Lovoskii Ordena Lenina gosudarstvennikh Universitet im. I. Franko. 20pp. (In Russian.)

- 1965 b. Trematode larvae, parasites of the Black Sea mollusc Nassa reticulata var. pontica Mont. In: Bentos. Naukova Dumka, Kiev, pp. 122-138. (In Russian.)

1966a. Helminthfauna of molluscs of the family Veneridae from the oceans of the world. In: Questions of marine biology. Essays for the symposium of young scientists. (Sevastopol, 13-16 April 1966). Naukova Dumka, Kiev, pp. 31-33. (In Russian.)

-1966 b. Helminth fauna of molluscs from Novorossiysk Bay. Biologiya Morya, Kiev. Helminthofauna of animals of the southern seas, pp. 114-133. (In Russian.)

1968. Helminthfauna of molluses of the northern part of the Black Sea. Biologiya Morya, Kiev 14: 114-126. (In Russian.)

1970. Material on the helminth fauna of molluscs on the Caucasian coasts of the Black Sea. Biologiya Morya, Kiev 20: 3-28. (In Russian.)

_ \& Naidenova, N. N. 1967. The biology of Diphterostomum brusinae (Stossich, 1899) Stossich, 1914. Zoologicheskii Zhurnal 46: 1094-1097. (In Russian.)

Dollfus, R. P. 1925. Liste critique des cercaires marines à queue sétigère signalées jusqu'à présent. Travaux de la Station Zoologique de Wimereux 9: 43-65.

- 1937. Les trématodes Digenea des sélaciens (Plagiostomes). Catalogue par hôtes. Distribution géographique. Annales de Parasitologie humaine et comparée 15: 57-73.

Durio, W. O. \& Manter, H. W. 1968. Some digenetic trematodes of marine fishes of New Caledonia. Part 1. Bucephalidae, Monorchiidae, and some smaller families. Proceedings of the Helminthological Society of Washington 35: 143-153.

Edwards, F. W. 1923. A preliminary revision of the crane-flies of New Zealand (Anisopodidae, Tanyderidae, Tipulidae). Transactions and Proceedings of the New Zealand Institute 54: 265-352.

Ergens, R. 1960. Gelmintofauna nekotorych ryb Albanii. Československa Parasitologie 7: 49-90. (In Russian.)

Fantham, H. B. 1938. Lecithostaphylus spondyliosomae n. sp., a trematode parasite of the hottentot fish, Spondyliosoma blochii, found in South African waters. Transactions of the Royal Society of South Africa 26: 387-393.

Filippi, F. de 1854. Mémoire pour servir à l'histoire génétique des trématodes. Turin, 30pp. Also (1854) Annales des Sciences Naturelles, Paris (Zool.) (4 ser.) 2: 255-284.

1855. Deuxième mémoire pour servir à l'histoire génétique des trématodes. Turin, 26pp. Also (1857) Memorie della (Reale) Accademia della Scienze di Torino (2 ser.) 16: 419-442.

Fischthal, J. H. 1980. Some digenetic trematodes of marine fishes from Israel's Mediterranean coast and their zoogeography, especially those from Red Sea immigrant fishes. Zoologica Scripta 9: 11-23.

- \& Thomas, J. D. 1968. Digenetic trematodes of some freshwater and marine fish from Ghana. Proceedings of the Helminthological Society of Washington 35: 126-140.

Gaevskaya, A. V. 1972. Effect of light and water temperature on the emergence of some species of cercariae from Black Sea mollusks. Gidrobiologicheskii Zhurnal 8(5): 104-105. (In Russian; English translation: Hydrobiological Journal 8(5): 84-85.)

\& Kovaleva, A. A. $1980 a$. On the reasons of similarity and differences in parasitofauna of two subspecies of common horse-mackerel of the Atlantic Ocean. Nauchnyi Doklady Vyssnei Shkoly. Biologicheskie Nauki (6): 52-56. (In Russian.)

$-\&-1980 b$. Ecological-geographical pecularities of parasitic fauna of the Atlantic horsemackerel. Trudy AtlantNIRO (Study in the Atlantic Biological Resources), 18-24. (In Russian.)

_ \& 1 1982. Trematodes infesting the Atlantic horse mackerels of the genus Trachurus. Gidrobiologicheskii Zhurnal 18(1): 60-65. (In Russian; English translation: Hydrobiological Journal 18(1): 50-55.)

Gambino, J. J. 1959. The seasonal incidence of infection of the snail Nassarius obsoletus (Say) with larval trematodes. Journal of Parasitology 45: 440 \& 456.

Giard, A. 1897. Sur un cercaire sétigère (Cercaria lutea), parasite des pélécypodes. Comptes Rendus des Séances de la Société de Biologie 49: 954-956.

1907. Sur les trématodes margaritigènes du Pas-de-Calais (Gymnophallus somateriae Levinsen et $G$. bursicola Odhner). Comptes Rendus des Séances de la Société de Biologie 63: 416-420.

Gibson, D. I. 1971 Studies of some helminth parasites of the flounder Platichthys flesus (L.). PhD Thesis, University of Aberdeen, 375pp.

1972. Flounder parasites as biological tags. Journal of Fish Biology 4: 1-9.

- \& Bray, R. A. 1977. The Azygiidae, Hirudinellidae, Ptychogonimidae, Sclerodistomidae and Syncoeliidae (Digenea) of fishes from the north-east Atlantic. Bulletin of the British Museum (Natural History) (Zoology) 32: 167-245. 
\& 1 1986. The Hemiuridae (Digenea) of fishes from the north-east Atlantic. Bulletin of the British Museum (Natural History) (Zoology) 51(1): 1-125.

Gijon, H., Lopez-Roman, R., De Armas, F. \& Valladares, B. 1982. Some Digenea of marine fish in the Canary Islands. Molecular and Biochemical Parasitology (Supplement: Parasites - their world and ours. Abstracts of the Fifth International Congress of Parasitology, Toronto, Canada, 7-14 August, 1982), 712.

Goldschmidt, R. B. 1902. Ueber Bau und Embryonalentwickelung von Zoogonus mirus Lss. Centralblatt für Bakteriologie, Parasitenkunde und Infektionskrankheiten 32: 870-876.

- 1905. Eireifung, Befruchtung und Embryonalentwicklung des Zoogonus mirus Lss. Zoologische Jahrbücher (Anatomie) 21: 607-654.

Graeffe, E. 1860. Beobachtungen über Radiaten und Würmer in Nizza. Neue Denkschriften der Allgemeinen Schweizerischen Gesellschaft für die Gesammten Naturwissenschaften 17: 59pp.

Grégoire, V. 1901. La réduction dans le Zoogonus mirus Lss. et le 'Primärtypus'. Cellule 25: 243-287.

Gupta, A. N. \& Sharma, P. N. 1974. Studies on digenetic trematodes from marine fishes of Indian waters. Part III. Anales del Instituto de Biologia. Universidad de México (serie Ciencias del Mar y Limnologia) 43: 93-102.

Ichihara, A., Kato, K., Kamegai, S., Kamegai, S., Nonobe, H. \& Machida M. 1966. On the parasites of fishes and shell-fishes in the Bay of Tokyo. (No. 5) Parasites of Kareius bicoloratus (Basilewsky). Meguro Kiseichu Kan Geppo (Monthly Report Meguro Parasitological Museum) (85-87): 2-14.

Isakova-Keo, M. M. 1952. Parasite fauna of Leuciscus brandti and its specificity. Uchenȳe Zapiski Leningradskogo Ordena Lenina Gosudarstvennogo Universitita (141) Ser. biol. nauk. (28), 230-237. (In Russian.)

Issaitschikov, I. M. 1928. Contributions to parasitic worms of some groups of vertebrates from Russian Arctic. Trudy Morskogo Nauchnogo Instituta 3(2): 1-79. (In Russian; partial English Translation: 1933 Trudy Gosudarstvennogo Okeanograficheskogo Instituta 3(1): 37-44.)

James, B. L., Sannia, A. \& Bowers, E. A. 1977. Parasites of birds and shellfish. In: A. Nelson-Smith \& E. M. Bridges (Eds), Problems of a small estuary. Proceedings of Symposium on the Burry Inlet (South Wales), Swansea, 13-18 Sept., 1976. Section 6(1), 17pp.

Johnstone, J. 1909. Internal parasites and diseased conditions of fishes. Proceedings and Transactions of the Liverpool Biological Society (1908-1909) 23: 189-202.

Kamegai, S. 1973. Zoogonid trematodes from marine fishes near the Tsushima Islands in the Sea of Japan. Research Bulletin of the Meguro Parasitological Museum 7: 19-23.

Køie, M. 1968. Buccinum undatum's larvale trematoder, deres indflydelse på vaertens ferlilitet og udvikling af de sekundaere kønskarakterer. Tiedoksianto-Information 9: 21-22.

1969. On the endoparasites of Buccinum undatum L. with special reference to the trematodes. Ophelia 6: 251-279.

1971. On the histochemistry and ultrastructure of the tegument and associated structures of the cercaria of Zoogonoides viviparus in the first intermediate host. Ophelia 9: 165-206.

1974. The fine structure of rediae and daughter sporocysts in relation to their effect on the host.

Proceedings of the 3rd International Congress of Parasitology (Munich) 1: 417-418.

1976. On the morphology and life-history of Zoogonoides viviparus (Olsson, 1868) Odhner, 1902 (Trematoda, Zoogonidae). Ophelia 15: 1-14.

1980. On the morphology of the miracidia of Derogenes varicus (Hemiuridae) and Zoogonoides viviparus (Zoogonidae). Proceedings of the 3rd European Multicolloquium of Parasitology (Cambridge), 185.

1981. Digenetic trematodes in some gadid and pleuronectid fishes from Danish waters. Information. Åbo Akademi 16: 61-62.

1983. Digenetic trematodes from Limanda limanda(L.)(Osteichthyes, Pleuronectidae) from Danish and adjacent waters, with special reference to their life-histories. Ophelia 22: 201-228.

Korotaeva, V. D. 1975. Contribution to the fauna of helminths and parasitic crustaceans of marine commercial fishes of the Australian and New Zealand waters. Trudy biologo-pochvenn'i Institut. Vladivostok (Novaja serija) 26: 46-60. (In Russian.)

1982. The fauna of trematodes in fishes of the order Zeiformes. Parazitologiya 16: 464 468. (In Russian.)

Kovaleva, A. A. 1969. Helminth fauna of Trachurus in the Atlantic Ocean basin. Materialy Nauchnol Konferentsii Vsesoyunogo Obshchestra Gel'mintologov, (1): 129-134. (In Russian.)

1970. Helminth fauna of the mackerel genus Trachurus (Carangidae, Perciformes) in the Atlantic Ocean basin. Biologiya Morya, Kiev 20: 37-66. (In Russian.)

Lammert, H. 1974. Einige Beobachtungen zur Parasitologie der Seezunge, Solea solea (L.). Bericht der Deutschen Wissenschaftlichen Kommission für Meeresforschung 23: 149-152.

Lauckner, G. 1973. Fischpathologische Untersuchungen. Jahresbericht Biologische Ansalt Helgoland (1972): 73-74. 
1980. Diseases of Mollusca: Gastropoda. In: O.Kinne (Ed.), Diseases of marine animals. Volume 1, General aspects, Protozoa to Gastropoda. John Wiley \& Sons, Chichester, pp.311-424.

- 1983. Diseases of Mollusca: Bivalvia. In: O. Kinne (Ed.), Diseases of marine animals. Volume 2. Introduction, Bivalva to Scaphopoda, Biologische Anstalt Helgoland, Hamburg, pp. 477-961.

Lebour, M. V. 1908. Fish trematodes of the Northumberland coast. Report on the Scientific Investigations. Northumberland Sea Fisheries Committee. (1907), 23-67.

1918. A trematode larva from Buccinum and notes on trematodes from post-larval fish. Journal of the Marine Biological Association of the United Kingdom, (n.s.) 11: 514-518.

Leidy, J. 1891. Notices of entozoa. Proceedings of the Academy of National Sciences of Philadelphia 42: $410-418$.

Linkletter, L. E., Lord, E.I. \& Dadswell, M.J. 1977. A checklist of marine fauna and flora of the Bay of Fundy. Huntsman Marine Laboratory, St. Andrews, 68pp.

Linton, E. 1915. Note on trematode sporocysts and cercariae in marine mollusks of the Woods Hole region. Biological Bulletin. Marine Biological Laboratory, Woods Hole, Massachusetts 28: 198-209.

Little, P. A. 1929. The trematode parasites of Irish marine fishes. Parasitology 21: 22-30.

Looss, A. 1901. Ueber einige Distomen der Labriden des Triester Hafens. Centralblatt für Bakteriologie, Parasitenkunde und Infektionskrankheiten 29: 398-405, 437-442.

Lunetta, J. E. \& Vernberg, W. B. 1971. Fatty acid composition of parasitized and nonparasitized tissue of the mud-flat snail, Nassarius obsoleta (Say). Experimental Parasitology 30: 244-248.

Mackenzie, K. 1968. Some parasites of O-group plaice, Pleuronectes platessa L., under different environmental conditions. Marine Research No. 3: 23pp.

_ \& Gibson, D. I. 1970. Ecological studies of some parasites of plaice Pleuronectes platessa $\mathrm{L}$. and flounder Platichthys flesus (L.). Symposia of the British Society of Parasitology 8: 1-42.

Madhavi, R. 1979. Digenetic trematodes from marine fishes of Waltair coast, Bay of Bengal. Family Zoogonidae. Rivista di Parassitologia 40: 249-259.

Maghraby, A. M. El \& Perkins, E. J. 1956. Additions to the marine fauna of Whitstable. Annals and Magazine of Natural History. (ser. 12) 9:481-496.

Manger, B. R. 1972. Some cestode parasites of the elasmobranchs Raja batis and Squalus acanthias from Iceland. Bulletin of the British Museum (Natural History) (Zoology) 24: 161-181.

Manter, H. W. 1934. Some digenetic trematodes from deep-water fish of Tortugas, Florida. Papers from Tortugas Laboratory 28: 257-346.

- 1947. The digenetic trematodes of marine fishes of Tortugas, Florida. The American Midland Naturalist 38: $257-416$.

McDaniel, J. S. \& Coggins, J. R. 1971. Seasonal trematode infection dynamics in Nassarius obsoletus. Journal of Elisha Mitchell Scientific Society 87: 169.

\& \& 1972. Seasonal larval trematode infection dynamics in Nassarius obsoletus (Say.). Journal of the Elisha Mitchell Scientific Society 88: 55-57.

McIntosh, W. C. 1927. Additions to the marine fauna of St. Andrews since 1874. Annals and Magazine of Natural History (ser. 9) 19: 49-94.

McVicar, A. H. 1977. Intestinal helminth parasites of the ray Raja naevus in British waters. Journal of Helminthology 51: 11-21.

Miller, H. M. Jr. \& Northup, F. E. 1926. The seasonal infestation of Nassa obsoleta (Say) with larval trematodes. Biological Bulletin. Marine Biological Laboratory, Woods Hole, Massachusetts 50: 490-508.

Miller, M. J. 1941. A critical study of Stafford's report on 'Trematodes of Canadian fishes' based on his trematode collection. Canadian Journal of Research 19D: 28-52.

Molin, R. 1859. Prospectus helminthum, quae in parte secundum prodromi faunae helminthologicae Venetae continentur. Sitzunsberichte der Akademie der Wissenschaften Mathematisch-Naturwissenschaftliche Classe, Wien, (1858) 33: 287-302.

Montgomery, W. R. 1957. Studies on digenetic trematodes from marine fishes of La Jolla, California. Transactions of the American Microscopical Society 76: 13-36.

Monticelli, F.S. 1890. Elenco degli elminti studiati a Wimereux nella primavera del 1889. Bulletin Scientifique de la France de la Belgique 22(ser. 4): 417-444.

1893. Studii sui trematodi endoparassiti: Primo contributo di osservazioni sui Distomidi. Zoologische Jahrbucher (Systematik), (supplement 3), 1-229.

Müller, O. F. 1780. Zoologia Danica seu animalium Daniae et Norvegiae rariorum ac minus notorum icones. Fasciculus secondus continens tabulas XLI-LXXX. Havniae, 4pp., 40pls.

Myers, B. J. 1959. Parasites from elasmobranch hosts from the Magdalen Islands region of the Gulf of St. Lawrence. Canadian Journal of Zoology 37: 245-246.

Nahhas, F. M. \& Cable, R. M. 1964. Digenetic and aspidogastrid trematodes from marine fishes of Curacao and Jamaica. Tulane Studies in Zoology 11: 167-228. 
Naidenova, N. N. 1967. Study of the helminth fauna of Gobius niger Linne in the Black Sea. Problemy Parazitologii. Trudy Nauchnoi Konferentsii. Parasitologov USSR. Kiev 5: 486-488. (In Russian.)

Nicoll W. 1907. A contribution towards a knowledge of the entozoa of British marine fishes. Annals and Magazine of Natural History (ser. 7) 19: 66-94.

1909. A contribution towards a knowledge of the entozoa of British marine fishes. Annals and Magazine of Natural History (ser. 8) 4: 1-25.

1910. On the entozoa of fishes from the Firth of Clyde. Parasitology 3: 322-359.

1912. On two trematode parasites from British food-fishes. Parasitology 5: 197-202.

1913. Trematode parasites from the food-fishes of the North Sea. Parasitology 6: 188-194.

1914. The trematode parasites of fishes from the English Channel. Journal of the Marine Biological Association of the United Kingdom, n.s. 10: 466-505.

1915. A list of the trematode parasites of British marine fishes. Parasitology 7: 339-378.

\& Small, W. 1909. Notes on larval trematodes. Annals and Magazine of Natural History (ser. 8) 3: 237-246.

Odhner, T. 1902. Mitteilungen zur Kenntnis der Distomen. I. Centralblatt für Bakteriologie, Parasitenkunde und Infektionskrankheiten 31: 58-69.

1911a. Zum natürlichen System der digenen Trematoden. II. Zoologischer Anzeiger 37: 237-253.

1911b. Zum natürlichen System der digenen Trematoden. III. (Ein weiterer Fall von sekundärem Anus.). Zoologischer Anzeiger 38: 97-117.

Olsson, P. 1868. Entozoa, iakttagna hos skandinaviska hafsfiskar. 1. Platyelminthes. Acta Universitatis Lundensis 4: 1-64.

Orlowska, K. 1980. Parasites of North Sea spiny dogfish, Squalus acanthias L. (Selachiiformes, Squalidae). Acta Ichthyologica et Piscatoria 9(1): 33-44.

Orrhage, L. 1973. Description of the metacercaria of Zoogonoides viviparus (Olsson, 1868) Odhner, 1902 with some remarks on life-cycles in the genus Zoogonoides (Trematoda, Digenea, Zoogonidae). Zoologica Scripta 2: 179-182.

Overstreet, R. M. 1969. Digenetic trematodes of marine teleost fishes from Biscayne Bay, Florida. Tulane Studies in Zoology and Botany 15: 119-176.

\& Pritchard, M.H. 1977. Two new zoogonid Digenea from deep-sea fishes in the Gulf of Mexico. Journal of Parasitology 63: 840-844.

Palombi, A. 1930. Il ciclo biologico di Diphterostomum brusinae Stossich (Trematode digenetico: fam. Zoogonidae Odhner). Considerazioni sui cicli evolutivi delle species affini e dei trematodi in general. Pubblicazione della Stazione Zoologica di Napoli 10: 111-149.

- 1931. Rapporti genetici tra Lepocreadium album Stossich e Cercaria setifera (non Joh. Muller) Monticelli. Bollettino di Zoologia 2: 165-171.

Papoutsoglou, S. E. 1976. Metazoan parasites of fishes from Saronicos Gulf, Athens-Greece. Thalassographica 1: 69-102.

Parker, R. E. 1973. Introductory statistics for biology. Institute of Biology's Studies in Biology, No. 43. Edward Arnold, London. 122pp.

Parona, C. 1912. L'elmintologia italiana da'suoi primi tempi all'anno 1910. Bibliografia, sistematica, corologia storia. vol. 2. Sistematica, corologia, storia. Novara, 540pp.

Parukhin, A.M. \& Lyadov, V. N. 1979. New genus and species of trematodes fish parasites in the Subantarctic zone of the Indian Ocean. Zoologicheskil Zhurnal 58: 637-642. (In Russian.)

Pelseneer, P. 1906. Trématodes parasites de mollusques marins. Bulletin Scientifique de la France et de la Belgique 40: 161-186.

Polyansky, Y. I. 1955. Studies on the parasitology of the fish in the northern Seas of the USSR. Parasites of fish of the Barents Sea. Trudy Zoologicheskogo Instituta 19: 5-170. (In Russian; English Translation (1966) Israel Program for Scientific Translations, Cat. No. 1655, 158pp.)

Prévot, G. 1966. Sur deux trématodes larvaires d'Antedon mediterranea Lmk (Echinoderme): Metacercaria sp. (Monorchiidae Odhner, 1911), et métacercaire de Diphterostomum brusinae Stoss., 1904 (Zoogonidae Odhner, 1911). Annales de Parasitologie humaine et comparée 41: 233-242.

Rees, G. 1953. Some parasitic worms from fishes off the coast of Iceland. II. Trematoda (Digenea). Parasitology 43: 15-26.

Reimer, L. W. 1984. Investigations of shallow and deepwater prawns and fishes on parasites and a short note on biomass of plancton of the coast of the P.R. of Mozambique. Fischerei-Forschung Wissenschaftliche Schriftenreihe 22: 27-35.

Richard, J. 1971. La chêtotaxie des cercaires valeur systématique et phylétique. Mémoires du Muséum d'Histoire Naturelle. Paris (ser. A) 67: 1-179.

Riel, A. 1975. Effect of trematodes on survival of Nassarius obsoletus (Say). Proceedings of the Malacological Society of London 41: 527-528. 
Rudophi, C. A. 1819. Entozoorum synopsis accedunt mantissa duplex et indices locupletissimi. Berolini, $811 \mathrm{pp.}$

Schaefer, C. W., Milch, P. \& Levin, N. L. 1970. Effects of trematode infection on resistance to dessication in the mud snail, Nassarius obsoletus (Say). Proceedings of the Symposium on Mollusca held at Cochin from January 12 to 16, 1968, Symposium Series 3, Mandapan Camp: 805-813.

Schilansky, M. M., Levin, N. L. \& Fried, G. H. 1977. Metabolic implications of glucose-6-phosphate dehydrogenase and lactic dehydrogenase in two marine gastropods. Comparative Biochemistry and Physiology 56B: 1-4.

Schreiner, A. \& Schreiner, K. E. 1908. Neue Studien über die Chromatinreifung der Geschlechtzellen. V. Die Reifung der Geschlechtszellen von Zoogonus mirus Lss. Skrifter udgivne af Videnskabsselskabet $i$ Christiania (8), 24pp.

Scott, J.S. 1973. Variation in the food of American plaice (Hippoglossoides platessoides) with fish length and locality in the Scotian Shelf and Gulf of St. Lawrence. Fisheries Research Board of Canada, Technical Report 411, 14pp.

- 1975a. Incidence of trematode parasites of American plaice (Hippoglossoides platessoides) of the Scotian shelf and Gulf of St. Lawrence in relation to fish length and food. Journal of the Fisheries Research Board of Canada 32: 479-483.

1975b. Geographic variation in incidence of trematode parasites of American plaice (Hippolossoides platessoides) in the Northwest Atlantic. Journal of the Fisheries Research Board of Canada 32: 547-550.

1982. Digenean parasite communities in flatfishes of the Scotian Shelf and southern Gulf of St. Lawrence. Canadian Journal of Zoology 60: 2804-2811.

Sey, O. 1970. Parasitic helminths occurring in Adriatic fishes. Part II (Flukes and tapeworms). Acta Adriatica 13(6): 3-15.

Shaw, C. R. 1933. Observations on Cercariaeum lintoni Miller and Northup and its metacercarial development. Biological Bulletin. Marine Biological Laboratory, Woods Hole, Massachusetts 64: 262-275.

Shimazu, T. 1974. Pseudozoogonoides ugui sp. nov., a new digenetic trematode from the dace, Tribolodon hakonensis, from Hokkaido, Japan (Trematoda: Zoogonidae). Bulletin of the Japanese Society of Scientific Fisheries 40: 433-438.

Shulman, S. S. \& Shulman-Albova, R. E. 1953. Parasites of fishes of the White Sea. Izdatel'stvo Akademii Nauk SSSR: Moscow, Leningrad, 198pp. (In Russian.)

Shulman-Albova, R. E. 1952. Fish parasites of the White Sea around the village of Gridina. Part I. Monogenetic and digenetic trematodes. Uchenye Zapiski Karelo-Finskogo Gosudarstvennogo Universiteta 4(3): 78-97. (In Russian.)

Sindermann, C. F. 1960 . Ecological studies of marine dermatitis producing schistosome larvae in northern New England. Ecology 41: 678-684.

Sinitsin, D. 1911. The parthogenetic generation of the trematodes and their descendants in the Black Sea molluscs. Zapiski Imperatorskoi Akademii Nauk po Fiziko-Matematicheskou Otdeleniyu, S.-Petersburg 30: 127pp. (In Russian.)

Skrjabin, K. I. 1957. Superfamily Zoogonoidea Skrjabin, 1957. In: K. I. Skrjabin(Ed.), Trematodes of animals and man. Principles of trematodology, Izdatel'stvo Akademii Nauk SSSR: Moscow 13: 5-162. (In Russian.)

Sproston, N. G. 1939. Notes sur la Faune parasitaire des Poissons à Roscoff. Travaux de la Station biologique de Roscoff 16: 33-58.

Stafford, J. 1904. Trematodes from Canadian fishes. Zoologischer Anzeiger 27: 481-495.

— 1905. Trematodes from Canadian Vertebrates. Zoologischer Anzeiger 28: 681-694.

- 1907. Preliminary report on the trematodes of Canadian marine fishes. Further Contributions to Canadian Biology and Fisheries (1902-05): 91-94.

Stambaugh, J. E. \& McDermott, J. J. 1969. The effects of trematode larvae on the locomotion of naturally infected Nassarius obsoletus (Gastropoda). Proceedings of the Pennsylvania Academy of Science 43: 226-231.

Stossich, M. 1888. Appendice al lavoro 'I distomi dei pesci marini e d'acqua dolce'. Programma del Ginnasio comunale superiore di Trieste dell'anno 35, 1887-8: 95-105.

1889. Brani di Elmintologia tergestina. Serie sesta. Bolletino della Società Adriatica di Scienze naturali in Trieste 11: 23-30.

1890. Brani di Elmintologia tergestina. Serie settima. Bolletino della Società Adriatica di Scienze naturali in Trieste 12: 39-46.

1899. Los membramento dei Brachycoelium. Bolletino della Società Adriatica di Scienze naturali in Trieste 19: 7-10.

1903. Note distomologiche. Bolletino della Società Adriatica di Scienze naturali in Trieste 21: $193-201$.

Stunkard, H. W. 1932. Some larval trematodes from the coast in the region of Roscoff, Finistère. Parasitology 24: 321-343. 
99.

1936. The life cycle of Cercariaeum lintoni Miller and Northup. Journal of Parasitology 22: 542-543.

1938. Distomum lasium Leidy, 1891 (syn. Cercariaeum lintoni Miller and Northup, 1926), the larval stage of Zoögonus rubellus (Olsson, 1868) (syn: Z. mirus Looss, 1901). Biological Bulletin. Marine Biological Laboratory, Woods Hole, Massachusetts 75: 308-334.

1941. Specificity and host-relations in the trematode genus Zoögonus. Biological Bulletin. Marine Biological Laboratory, Woods Hole, Massachusetts 81: 205-214.

1972. Observations on the morphology and life-history of the digenetic trematode, Lepocreadium setiferoides (Miller \& Northup, 1926) Martin, 1938. Biological Bulletin. Marine Biological Laboratory, Woods Hole, Massachusetts 142: 326-334.

Threlfall, W. 1969. Some parasites from elasmobranchs in Newfoundland. Journal of the Fisheries Research Board of Canada 26: 805-811.

Thulin, J. 1981. Sjukdomar och parasiter hos fisk vid Barsebäcksoverket 1980. Naturvårdsverket Meddelande, snv pm, (1429), 31pp.

Timon-David, J. 1933. Contributions à l'étude du cycle évolutif des zoogonides (trématodes). Comptes Rendus hebdomadaires des séances de l'Académie des Sciences, Paris 196: 1923-1924.

1934. Recherches sur les Trématodes parasites des oursins en Mediterranée. Bulletin de l'Institut oceanographique, Monaco 652: 1-16.

1937a. Sur l'évolution experimentale des metacercaires de Zoogonus mirus Looss, 1901 (Trematodes, famille des Zoogonidae). Compte Rendu de l'Association Francaise pour l'Avancement des Sciences (Marseilles, 1936) 60: 274-276.

1937b. Étude sur les Trématodes parasites des poissons du golfe de Marseille (Première liste). Bulletin de l'Institut Oceanographique, Monaco 717: 1-24.

1938. On parasitic trematodes in echinoderms. In: Livro Jubilar do Professor Lauro Travassos, Rio de Janeiro, pp. 467-473.

Tkachuk, L. P. 1979. New species of trematodes from the deep-water Zeidae of the Indian and Atlantic Oceans. Zoologicheskǐ Zhurnal 58: 1290-1295. (In Russian.)

Umnova, B. A. 1979. Ecological analysis of trematode-fauna in fish of Gadidae fam. and of Turbot fam. in N.W. Atlantic. In: O. N. Bauer et al. (Eds) Tezisȳ Dokladov. VII All Union Conference on fish parasites and diseases (Leningrad). 'Nauka' Leningradskoe Otdelenie; Leningrad, pp. 109-110. (In Russian.)

Van Beneden P. J. 1871. Les poissons des cotes de Belgique, leur parasites et leurs commensaux. Memoires de l'Academie Royale des Sciences, des Lettres et des Beaux-Arts 38: $\mathrm{xx}+100$.

1875. Les commensaux et les parasites dans la regne animal. Bibliotheque scientifique internationale; Paris, 238pp.

1876. Animal parasites and messmates. Henry S. King \& Co.; London, 274 pp.

Vernberg, W. B. 1961 . Studies on oxygen consumption in digenetic trematodes. VI. Influence of temperature on larval trematodes. Experimental Parasitology 11: 270-275.

1961b. The influences of temperature on metabolic response in larval trematodes. Journal of Parasitology 47: 43.

1968. Platyhelminthes: respiratory metabolism. In: M. Florkin \& B. T. Scheer (Eds), Chemical Zoology. Vol. II. Porifera, Coelenterata and Platyhelminthes. Academic Press Inc., New York \& London, pp 359-393.

1969. Adaptations of host and symbionts in the intertidal zone. American Zoologist 9: 357-365.

\& Vernberg, F. J. 1963. Influence of parasitism on thermal resistance of the mud-flat snail, Nassarius obsoleta Say. Experimental Parasitology 14: 330-332.

$-\&-1965$. Interrelationships between parasites an their hosts-1. Comparative metabolic patterns of thermal acclimation of larval trematodes with that of their host. Comparative Biochemistry and Physiology 14: 557-566.

1 \& $\&$ 1966. Comparative patterns of thermal acclimation of larval trematodes and their host. Proceedings of the 1st International Congress of Parasitology (Rome, 1964) 1: 81-82.

$-\&-1967$. Interrelationships between parasites and their hosts. III. Effect of larval trematodes on the thermal metabolic response of their molluscan host. Experimental Parasitology 20: 225-231.

$-\&-1968$. Interrelationships between parasites and their hosts. IV. Cytochrome c oxidase thermalacclimation patterns in a larval trematode and its host. Experimental Parasitology 23: 347-354.

\& \& 1971. Respiratory metabolism of a trematode metacercaria and its host. In: T. C. Cheng (Ed.), Aspects of the biology of symbiosis. Univ. Park Press, Baltimore, USA, pp. 91-102.

,-- \& Beckerdite, F. W. 1969. Larval trematodes: Double infections in common mud-flat snail. Science, New York (3885) 164: 1287-1288. 
Villot, F.-C.-A. 1878. Organisation et développement de quelques espèces de Trématodes endoparasites marins. Annales des Sciences Naturelles (ser. 6) 8: Art. No. 2: 40pp.

Vlasenko, P. 1931. Zur Helminthofauna der Schwarzmeerfische. Trudy Karadah'skoyi Nauchnoyi Stantsiyi T. I. Vyazems'koho 4: 88-136. (In Russian.)

Von Baer K. E. 1826. Sur les entozoaires ou vers intestinaux. Bulletin des Sciences Naturelles et de Geologie 9: 123-126.

Wassermann, F. 1913. Die Oogenese des Zoogonus mirus Lss. Archiv für Mikroskopische Anatomie 83 (Abt 2): 1-140.

Wickins, J. F. \& Macfarlane, I. S. 1973. Some differences in the parasitic fauna of three samples of plaice (Pleuronectes platessa L.) from the southern North Sea. Journal of Fish Biology 5: 9-19.

Willemse, J. J. 1968. Helminth and sporozoan parasites of fishes in the Netherlands. Bulletin Zoologisch Museum, Universiteit van Amsterdam 1: 83-97.

Yamaguti, S. 1934. Studies on the helminth fauna of Japan. Part 2. Trematodes of fishes, I. Japanese Journal of Zoology 5: 249-541.

1938. Studies on the helminth fauna of Japan, Part 21. Trematodes of fishes, IV. S. Yamaguti, Kyôto, 139pp.

1953. Systema helminthum. Part I. Digenetic trematodes of fishes. S. Yamaguti, Tokyo, 405pp.

1970. The digenetic trematodes of Hawaiian fishes. Keigaku Publishing Co, Tokyo, 436pp.

1971. Synopsis of digenetic trematode of vertebrates. Keigaku Publishing Co, Tokyo, Vols 1 and 2: 1074pp., 349pls.

Zaika, V. E. 1966. Metacercaria of trematods in the lancelet Branchiostoma lanceolatum (Pall.) of the Black Sea. Zoologicheskii Zhurnal 45: 768-769. (In Russian.)

Zdun, V. I. \& Ignatyev, S. M. 1980a. The Black Sea mollusc Cerithium vulgatum (Gastropoda, Cerithiidae), a new intermediate host of trematodes. Parazitologiya 14: 345-348. (In Russian.)

$-\&-1980 \mathrm{~b}$. On ecological-parasitological characteristics of molluscs of the Crimean shore, Black Sea. Tezisy Dokladov IX Konferentsiya Ukrainskogo Parazitologicheskogo Obshchestva, (2): 63-64. (In Russian.)

Zhukov, E. V. 1957. New genera and species of trematodes-parasites of fish in the far eastern seas. Zoologicheskii Zhurnal 36: 840-846. (In Russian.)

- 1960. Endoparasitic worms of the fishes in the sea of Japan and South-Kuril shallow-waters. Trudy Zoologicheskogo Instituta, Leningrad 28: 3-146. (In Russian.)

Zubchenko, A. V. 1978. New species of trematodes from fish of North Atlantic. Parazitologiya 12: 116-120. (In Russian.)

- 1980. Parasitic fauna of Anarhichadidae and Pleuronectidae of fish in the Northwest Atlantic. International Commission for the Northwest Atlantic Fisheries Selected Papers 6: 41-46.

1984. Ecological peculiarities of parasitic fauna of some Alepocephalidae. In: Y. I. Polyansky, K. V. Galaktionov \& A. A. Dobrovolsky (Eds.), Ecological-Parasitological Investigations of Northern Seas, Kola Branch of Academy of Sciences of the USSR, Murmansk Biological Institute, Apatity, pp. 77-81. (In Russian.) 


\section{$2 \mathrm{BHL}$ Biodiversity Heritage Library}

1986. "The Zoogonidae (Digenea) of fishes from the north-east Atlantic." Bulletin of the British Museum (Natural History) Zoology 51, 127-206. https://doi.org/10.5962/bhl.part.26969.

View This Item Online: https://www.biodiversitylibrary.org/item/19468

DOI: https://doi.org/10.5962/bhl.part.26969

Permalink: https://www.biodiversitylibrary.org/partpdf/26969

\section{Holding Institution}

Natural History Museum Library, London

\section{Sponsored by}

Natural History Museum Library, London

\section{Copyright \& Reuse}

Copyright Status: In copyright. Digitized with the permission of the rights holder.

Rights Holder: The Trustees of the Natural History Museum, London

License: http://creativecommons.org/licenses/by-nc-sa/4.0/

Rights: http://biodiversitylibrary.org/permissions

This document was created from content at the Biodiversity Heritage Library, the world's largest open access digital library for biodiversity literature and archives. Visit BHL at https://www.biodiversitylibrary.org. 